\author{
UNIVERSIDADE DE SÃO PAULO \\ FACULDADE DE FILOSOFIA, LETRAS E CIÊNCIAS HUMANAS \\ DEPARTAMENTO DE LETRAS CLÁSSICAS E VERNÁCULAS \\ PROGRAMA DE PÓS-GRADUAÇÃO EM LITERATURA BRASILEIRA
}

ISIDE MARIA LABATE MAIOLINI MESQUITA

Um romance de paradoxos: ficção, história e subjetividade em A menina morta de Cornélio Penna

Versão corrigida 
ISIDE MARIA LABATE MAIOLINI MESQUITA

\title{
Um romance de paradoxos: ficção, história e subjetividade em A menina morta de Cornélio Penna
}

\begin{abstract}
Versão corrigida
Dissertação de mestrado apresentada ao Programa de PósGraduação em Literatura Brasileira do Departamento de Letras Clássicas e Vernáculas da Faculdade de Filosofia, Letras e Ciências Humanas da Universidade de São Paulo, para a obtenção do título de mestre em Letras.
\end{abstract}

Orientador: Prof. Dr. Vagner Camilo 
MESQUITA, Iside M L M. Um romance de paradoxos: ficção, história e subjetividade em A menina morta de Cornélio Penna. Dissertação apresentada à Faculdade de Filosofia Letras e Ciências Humanas da Universidade de São Paulo para obtenção do título de mestre em Letras.

Aprovado em

\section{Banca Examinadora}

Prof. Dr. Instituição:

Julgamento: Assinatura:

Prof. Dr. Instituição:

Julgamento: Assinatura:

Prof. Dr. Instituição:

Julgamento: Assinatura: 
Aos meus amores,

Selmo, Fernando e Nana. 


\section{AGRADECIMENTOS}

A Vagner Camilo pelo estímulo e confiança no trabalho, rigor e argúcia na orientação, pelas tantas referências de leitura e enorme força nos momentos de dificuldade pessoal.

A Rodrigo Naves, pelo olhar apurado, pela leitura cuidadosa e pelas sugestões valiosas no exame de qualificação que ajudaram a reorientar o trabalho

A André Mota, pela leitura e importante contribuição no exame de qualificação.

A Nilza Micheletto pela leitura do trabalho em andamento, pela interlocução, incentivo e generosa contribuição na busca bibliográfica.

A Franklin Leopoldo e Silva, pelas decisivas indicações de leitura sobre o existencialismo cristão.

A Marina Sugaya, Fábio Alves, Paula Barbosa Maciel, Pedro Fragelli e Jefferson Donizetti, agradeço pela interlocução e companheirismo.

A Marli Tassinari, pelos perspicazes comentários de leitura.

Ao Alberto Tassinari, pelas sugestões bibliográficas e generosidade de emprestar diversos livros.

A Maria Cecília Pinho, pela ajuda imensa nos momentos difíceis.

A Nana, pelo amor, pela força e estímulo para que eu finalizasse este trabalho.

A Fernando, pelo amor e pelo apoio em todos os momentos.

A Selmo, pelo companheirismo, carinho e paciência de me ver tantas noites às voltas com a menina morta.

À minha família e aos amigos, que sempre me apoiaram, agradeço a todos e a cada um. 


\section{SUMÁRIO}

$\begin{array}{ll}\text { Introdução } & 9\end{array}$

Capítulo I - Lugar do romance 13

Capítulo II - Particularidades no tratamento da matéria histórica 40

Capítulo III - Sobre a construção da narrativa 59

Capítulo IV - Um olhar sobre a representação feminina 84

Capítulo V - Dimensão filosófico-religiosa da obra 116

$\begin{array}{ll}\text { Considerações finais } & 141\end{array}$

$\begin{array}{ll}\text { Referências bibliográficas } & 148\end{array}$ 


\section{Resumo}

O presente trabalho é sobre $A$ menina morta, último romance de Cornélio Penna, publicado em 1954. Esta leitura propõe uma reflexão das estruturas da sociedade rural brasileira, articulando a dimensão histórico-social a uma dimensão existencial. A relação íntima do enredo com uma doutrina filosófica ajuda a entender a feição do romance, com suas ambiguidades e paradoxos, e o coloca como um texto de alcance mais amplo, que vai para além dos fatos narrados. Poderíamos pensar mesmo que as ambiguidades e paradoxos constituem o princípio que o estrutura, e talvez possam ser entendidos como extensão das ambiguidades históricas e das dinâmicas da vida social no país, tendo em vista a particularidade do nosso processo de modernização, estruturado sobre a desigualdade e o atraso.

Palavras-chave: Cornélio Penna; romance; escravidão, Literatura Brasileira. 


\section{Abstract}

The present work consists of an analysis of Cornelio Penna's last novel published in 1954 . The study of this novel proposes a reflection of rural brazilian society structures, articulating a social-historical dimension to an existential one. The close relationship of the plot with a philosophical doctrine helps to understand the novel's ambiguities and paradoxes, and places it as a broader scope that goes beyond the facts narrated. We might even think that the ambiguities and paradoxes are the principle that structure, and maybe can be understood as an extension of the historical ambiguities and the dynamics of social life in the country, taking into account the particularity of our modernization process, structured on social inequality.

Key-words: Cornélio Penna; novel; slavery, Brazilian literature. 


\section{Introdução}

Publicado em 1954, o romance $A$ menina morta esteve por muito tempo à margem do cânone. São muitas as hipóteses que poderiam justificar sua rejeição por parte da crítica, tais como a aparente inatualidade da obra e a sua identificação a uma tendência espiritualista que se contrapunha ao Modernismo.

Ressalvados os estudos de Luiz Costa Lima sobre os escritos de Cornélio Penna ${ }^{1}$, o ensaio de Alexandre Eulálio ${ }^{2}$ e a dissertação de mestrado de Wander Melo Miranda nos anos $1970^{3}$, só a partir da década de 1990 , e sobretudo a partir de 2000 , houve um retorno à obra do romancista fluminense. ${ }^{4}$

\footnotetext{
${ }^{1}$ LIMA, Luiz Costa. A perversão do trapezista: o romance em Cornélio Penna, Rio de Janeiro, Imago, 1976 reeditado em 2005 sob o título O romance em Cornélio Penna, Belo Horizonte, Ed. UFMG, 2005.

. "Sob as trevas da melancolia: o patriarcado em A menina morta", In: A aguarrás do tempo: estudos sobre a narrativa, Rio de Janeiro, Rocco, 1989.

2 EULÁLIO, Alexandre. "Os dois mundos de Cornélio Penna”. In: WALDMANN, Berta; DANTAS, Luiz. Escritos. Campinas: Unicamp, 1992. pp.443-463.

${ }^{3}$ MIRANDA, Wander de Melo. A menina morta: a insuportável comédia, 1979, 143 fl. Dissertação (Mestrado
em Literatura Brasileira), Letras, Universidade Federal de Minas Gerais, Belo Horizonte, 1979.
}

${ }^{4}$ Com os trabalhos, entre outros, de:

SIMÕES, Irene Gilberto. Oficina de artista: a linguagem dos romances de Cornélio Penna, 1990, $237 \mathrm{fl}$. Tese (Doutorado em Teoria Literária e Literatura Comparada), FFLCH, Universidade de São Paulo, São Paulo, 1990.

HERBOLD, Hildegard. O sagrado e o profano na literatura intimista dos anos 1930/40 no Brasil: O exemplo de Lúcio Cardoso e Cornélio Pena. Dissertação de Mestrado em História Social, FFLCH, Universidade de São Paulo, São Paulo, 1993.

SCHINCARIOL, Marcelo T. Em busca da alma de Itabira: uma leitura de Cornélio Penna, Dissertação de Mestrado. Campinas: Instituto de Estudos da Linguagem da Universidade Estadual de Campinas, 2001.

SANTOS, Josalba Fabiana dos. Fronteiras da Nação em Cornélio Penna. 2004, 262 fl. Tese de Doutorado em Literatura Comparada, Letras, Universidade Federal de Minas Gerais, Belo Horizonte, 2004.

RUFINONI, Simone Rossinetti. Favor e Melancolia: Uma leitura de A menina morta, de Cornélio Pena, Tese (Doutorado em Literatura Brasileira), FFLCH, Universidade de São Paulo, São Paulo, 2005.

RODRIGUES, André Luis. Fraturas no olhar: Realidade e representação em Cornélio Penna,Tese de Doutorado em Literatura Brasileira, FFLCH, Universidade de São Paulo, São Paulo, 2006.

SCHINCARIOL, Marcelo T. A arte completa de ser infeliz: a ficção de Cornélio Penna, Tese de Doutorado em Teoria Literária, IEL, Universidade Estadual de Campinas, Campinas, 2009. 
Muito embora esse interesse mais recente seja de pouco alcance do público leitor, ${ }^{5} \mathrm{a}$ situação hoje não é a mesma da de alguns anos atrás, já tendo se configurado uma fortuna crítica que delineia diversas leituras da obra.

Sem a pretensão de repassar a bibliografia existente deste que é o último romance de Cornélio Penna, o presente trabalho retoma algumas das questões já abordadas pela crítica e levanta outras que não me parecem ainda suficientemente exploradas.

Seja pela caracterização dos personagens, pela construção do cenário, ou pelo modo como funde forma e conteúdo, Cornélio Penna é um grande narrador. No entanto, coloca algumas dificuldades ao leitor, provocando um estranhamento na leitura que já foi objeto de análise de parte da crítica.

Procurar entender essa inquietação que a obra cria é uma das propostas desse trabalho. A partir dos elementos que a constituem, como o tempo, o espaço, a galeria de personagens e, sobretudo, o foco narrativo, procurei analisar, em cada um dos capítulos, os principais pontos de questionamento que eles suscitam, formulando algumas hipóteses de interpretação.

Várias são as questões que chamam a atenção em $A$ menina morta. O autor retrocede quase um século para trazer à tona a matéria histórica, bem menos presente nas obras anteriores. E embora este seja seu último romance, o tempo em que se passa a narrativa precede as anteriores em termos cronológicos. Por que estaria o autor privilegiando aquele momento histórico, sob uma perspectiva disfórica num ambiente de euforia "nacional-desenvolvimentista" (como se convencionou chamar o projeto de modernização que vinha se anunciando desde os anos 30 no Brasil) é uma das perguntas que suscita. Estaria o autor apontando para as contradições do país, sugerindo uma modernidade que repõe elementos do atraso?

\footnotetext{
${ }^{5}$ Cornélio Penna que foi o segundo autor, depois de Manuel Bandeira a ser publicado na coleção "Romances Completos" da Ed. José Aguilar em 1958, teve sua obra esgotada por um longo período. A menina morta, seu último romance, tem sido encontrado recentemente em edição publicada em Portugal em 2006, em uma coleção destinada a obras de literatura brasileira. Foi mantida, portanto, a edição original, apenas com atualização ortográfica. Cf. PENNA, Cornélio. A menina morta. Lisboa: Cotovia, 2006. (Curso Breve de Literatura Brasileira, Vol. 9). Refletindo a retomada dos estudos e o aumento do reconhecimento da obra do autor, a Editora do SESI-SP publicou em 2017 seu romance de estreia, Fronteira (1935), e anunciou a publicação dos outros três, seguindo a ordem cronológica original dos lançamentos.
} 
Para além do deslocamento temporal, e tendo em vista que a forma classicizante que o autor elege retrocede a formas contestadas e abandonadas pelo Modernismo em um momento em que o projeto modernista já havia se consolidado, procuro verificar no primeiro capítulo os diálogos que a obra estabelece, e sua relação com a modernidade.

No segundo, dedico-me ao tratamento que o autor dá à matéria histórica, uma das singularidades do romance. Oscilando entre indefinição e precisão, de um lado temos a representação fiel da vida em um latifúndio cafeeiro na segunda metade do século XIX, explicitando a configuração social, a violência e a prepotência que ela implica, e de outro uma ambiguidade nas referências históricas que se confundem com a ambientação do mundo que retrata.

No capítulo seguinte, o foco recai sobre o modo como o autor constrói a narrativa, e o paradoxo de um narrador onisciente que parece desconhecer os fatos que narra, além de muitas vezes colar-se aos personagens, confundindo suas vozes.

Em função da centralidade ocupada pela voz feminina e pelo ponto de vista daquelas mulheres confinadas no ambiente familiar da casa-grande, procuro apontar também a posição da mulher em tensão com o mundo masculino, e como, embora subalterna e submetida por uma ordem masculina e patriarcal, é quem protagoniza a resistência àquele mundo.

Finalmente, e tendo em vista que permeiam a obra, ainda que de forma difusa, questões de ordem filosófica e religiosa articuladas à questão social, procuro identificá-las, sempre no intuito de esclarecer a perspectiva assumida pelo autor.

Ao lado de uma narrativa minuciosa, com descrições muito precisas que parecem nos remeter ao mundo narrado e que coloca a esfera social como determinante da condição dos sujeitos, há um texto marcadamente subjetivo, permeado de indefinições e mistérios, que corria contra a tendência realista dos romances dos anos de 1930.

Impregnado de um clima de abafamento e de uma angústia que imobiliza, ele parece indicar ainda não ter lugar ali qualquer ação mais afirmativa que aponte para superações. Daí a hipótese de que a questão que se coloca não é apenas social ou histórica, mas de fundo existencial e religioso. 
Assim, seja pelos enigmas e mistérios da trama, pelo seu deslocamento temporal ou estético, ou ainda pelos dois eixos sobre o qual se estrutura a narrativa, o romance $A$ menina morta provoca uma inquietação na leitura, motivo que instiga e convoca a uma aproximação mais cuidadosa. 


\section{Lugar do romance}

Muitas são as questões a que a leitura de $A$ menina morta nos remete, dentre as quais seu lugar na modernidade.

$\mathrm{Na}$ contramão das propostas estéticas do Modernismo e da prosa neorrealista que marca o chamado romance social de 30, Cornélio Penna lança seu primeiro romance, Fronteira (1935). É também na contramão do processo modernizador pelo qual o Brasil passava nos anos 50 , em que predominava o desejo de uma identidade que se pautasse no progresso e no desenvolvimento econômico, que ele lança este que é seu último romance.

Publicado em 1954, não é contemporânea nem a matéria de que trata, nem a forma de que se utiliza. O autor constrói a narrativa em torno do cotidiano de uma fazenda situada na região do Vale do Paraíba em meados do século XIX, compondo um painel da vida nas fazendas de café e das relações sociais que ali se estabelecem em torno de uma estrutura patriarcal e escravagista.

Ele parece retomar as narrativas oitocentistas, recusando as conquistas e inovações do movimento modernista, naquele momento já "rotinizadas" ${ }^{6}$, como a linguagem coloquial, as frases curtas, a experimentação da sintaxe e, sobretudo, a assimilação das vanguardas europeias. As frases de que o autor faz uso são, ao contrário, longas e sinuosas, pontuadas por adjetivos, e o vocabulário cuidadosamente escolhido, de maneira a adensar a atmosfera criada pela narrativa. A linguagem solene (mas sem afetação) se dá também no discurso do narrador, que se utiliza de um vocabulário pouco usual como ilustra o excerto abaixo, perfeitamente ajustado ao mundo que narra, reforçando a verossimilhança como um dos traços que caracterizam a obra.

\footnotetext{
A brisa morna enfunava as cortinas que balançavam com lenta majestade, sacudindo as franjas muito longas. Vinha lá de fora o odor poderoso da natureza enlanguescida, e Carlota despertara de sua sesta perturbada pela sensação de ter dormido muitos anos. (...) Já refeita, logo compreendeu não serem unicamente os eflúvios trazidos pela aragem que enchiam o quarto daquele capitoso olor e examinou tudo em volta, à procura das flores ou das frutas que assim indicavam a sua presença ali.
}

$\mathrm{Na}$ fala dos personagens, com exceção de um ou outro momento em que se atribuem a eles expressões próprias do discurso coloquial como "Vancê", corruptela de "você", ou

\footnotetext{
${ }^{6}$ Cf. CANDIDO, Antonio. "A revolução de 1930 e a cultura". In: A educação pela noite e outros ensaios. 3a.ed. 2a. reimpr. São Paulo: Ática, 2003, pp.181-198 e LAFETÁ, João Luiz. “Os pressupostos básicos”. In: 1930: A crítica e o Modernismo. 2a .ed. São Paulo: Duas Cidades e 34, 2000. Pp.19-38.
} 
"Nhanhã" (que sabemos ser o tratamento que os escravos davam às senhoras, principalmente às meninas e moças), ou ainda quando, em algumas das falas das escravas, da utilização de vocábulos com origem em línguas faladas na África centro-ocidental (sobretudo no Reino do Congo e em Angola) ${ }^{7}$, o discurso não se aproxima daquele que seria característico desses personagens, afastando-se da tendência modernista, em que há a preocupação não apenas em documentar os tipos humanos como a linguagem própria do meio social em que se inserem.

Ao lado das questões referentes à linguagem, o modo pelo qual o texto é construído também reforça a atmosfera de abafamento que o permeia. Conjugando uma forma classicizante e um conteúdo que dissolve os procedimentos e os limites dos próprios movimentos estéticos, Cornélio Penna constrói um texto denso que transmite um ambiente de sombras e fechamento, com expressões negativas que circunscrevem um vazio. 0 discurso elíptico, em que reitera o tempo todo as mesmas questões, parece elaborar esteticamente uma situação sem saída e cria um efeito de abafamento no leitor ${ }^{8}$.

Construído com argúcia, exige um leitor atento. É interessante observar, por exemplo, o comentário do narrador sobre uma das personagens: "Sinhá-Rola, perdida em sua dissertação, cheia de frases parasitárias, de circunlóquios, de detalhes ociosos, ..." ${ }^{\prime 9}$. Tendo em vista que tais características não se revelam nas falas da personagem e que temos uma narrativa abundante em detalhes, com períodos longos e frases intercaladas em que o narrador retoma temas e circunstâncias, podemos pensar que o autor estaria fazendo um comentário irônico sobre o modo como o texto pode ser lido.

A história é narrada por um narrador onisciente, supostamente objetivo, mas cuja precisão contraria a indefinição da narrativa, conforme será explicitado adiante.

Muito já se falou do deslocamento estético da obra do autor.

\footnotetext{
7 É o caso dos vocábulos "mironga", "muana", "malungo", "calundu" ou "banzo", usados entre os negros e cuja etimologia, conforme Novo Dicionário Banto do Brasil de Nei Lopes, tem origem no quimbundo ou no quicongo, ambas pertencentes ao tronco linguístico banto. LOPES, Nei. Novo Dicionário Banto do Brasil. Rio de Janeiro: Pallas, 2003. Reproduzidos exatamente de acordo com sua forma dicionarizada no português conforme Dicionário Houaiss, e incluídos em diálogos em que domina a língua culta, seu uso reforça a credibilidade da representação sem indicar, no entanto, qualquer preocupação de registro oral da linguagem.

${ }^{8}$ Para além da figura retórica, figura de ocultação, podemos pensar ainda na elipse como figura geométrica em
que coexistem dois focos: a História de um lado, e a transcendência, a espiritualidade, de outro.
} ${ }^{9}$ Penna, Cornélio. “A menina morta”. In: Romances completos. 1a.ed. Rio de Janeiro: José Aguilar. p.988. 
Para Tristão de Athayde a inatualidade consistiria em um dos méritos da obra, e se justificaria como desafio à "moda" então dominante ${ }^{10}$.

Para Mário de Andrade, além do ritmo "batido e monótono" dos romances que ele define como de um antiquário, Penna joga com o mal-estar, o sombrio e o insondável das vidas interiores, assim como com as fronteiras da loucura ao romper com a lógica da psicologia que predominava então na produção nacional. ${ }^{11}$

Luiz Costa Lima, por sua vez, defende que Cornélio Penna estaria fazendo em A menina morta um "romance do contramito", uma crítica ao mito do congraçamento proposto por Gilberto Freyre. Para o crítico, a "inatualidade" referida por Tristão de Ataíde não significaria uma recusa do autor ao experimentalismo contemporâneo, mas a indicação de incompatibilidade com quaisquer das formas já socializadas. O autor, segundo Costa Lima, teria optado por uma forma que permitisse objetivar a sensação permanente do mundo escravagista como pesadelo: o fantástico. Preso à realidade do passado e de seus antepassados, Penna se afastava "do véu de ilusão indispensável à ficção", configurando o passado nacional como matéria mítica e, portanto, intemporal, em uma moldura ficcional.

Ao dispensar as canalizações religiosa e literária, ao fugir do tempo de seus contemporâneos, o autor precisa inventar para si mesmo uma moldura ficcional que Ihe permitisse encarar a matéria bruta do mundo. Antes de consumá-la, dispunha apenas do fantástico. A configuração que afinal dá ao fantástico, lhe expõe a razão de seu pesadelo: o mundo da escravidão. ${ }^{12}$

\footnotetext{
${ }^{10}$ Quando do lançamento de Fronteira, seu primeiro romance, o crítico declara: "Ora, justo na hora em que toda a atenção se voltava para o romance social, que parecia tão de acordo com o novo estado de espírito em que a Revolução de 30 colocara a nova geração - aparece o romance do Sr. Cornélio Penna. - E aparece com a coragem de sua perfeita inatualidade, como um verdadeiro desafio à moda dominante. E nisto está o primeiro dos seus méritos". Cf.Ataíde, Tristão de. "Nota preliminar". In: Romances completos.1ạ.ed. Rio de Janeiro: José Aguilar. p.3.

${ }^{11}$ Mário de Andrade, em resenha do segundo romance do autor, publicado no Diário de Notícias do Rio de Janeiro em 1940, afirma: "Alma de colecionador, vivendo no convívio dos objetos velhos, Cornélio Pena sabe traduzir, como ninguém entre nós, o sabor de beleza misturado ao de segredo, de degeneração e mistério, que torna uma arca antiga, uma caixinha-de-música, um leque, tão evocativos, repletos de uma sobrevivência humana assombrada. Se sente que os seus romances são obras de um antiquário apaixonado, que em cada objeto antigo vê nascer uns dedos, uns braços, uma vida, todo um passado vivo, que a seu modo e em seu mistério ainda manda sobre nós. (...) No seu ritmo um pouco batido e monótono para o meu gosto da prosa, freqüentemente Cornélio Pena consegue páginas empolgantes em que joga com o mal-estar, o sombrio, 0 insondável das vidas interiores, e as fronteiras da loucura." ANDRADE, Mário de. "Romances de um antiquário". In: O empalhador de passarinho. Belo Horizonte: Itatiaia, 2002, p.128.
}

12 LIMA, Luiz Costa. O romance de Cornélio Penna. 2a.ed. revista e modificada. Belo Horizonte: UFMG, 2005, p.21. 
Em estudo mais recente, Simone Rufinoni revitaliza a discussão. Propondo uma reflexão sobre a questão do retorno à tradição como opção estética na obra de Penna, assim como o uso de uma forma híbrida de realismo e introspecção que marca seus romances, a crítica problematiza o conceito de realismo, sugerindo que a presença do realismo formal na narrativa se vincularia não apenas à realidade da qual trata, mas à necessidade estética de representar o atraso.

Em A menina morta, o retorno provém da natureza do objeto representado e da representação - olhar moderno que lança por sobre o passado os entraves e paradoxos da modernização conservadora, que se fazem estéticos. Ao lado disso, esse viés da fatura pode também condizer com certa inclinação ao viés classicizante oriundo da geração de 45 . A busca do realismo em A menina morta se faz pois em duas vias: como dado de 'estilo', a forma oitocentista articulada à introspecção moderna; e como 'verdade social', no sentido de apreensão artística do sentido de uma era. ${ }^{13}$

Em ensaio sobre A menina morta denominado "Autópsia da casa-grande", Roberto Vecchi indica também um duplo sentido para a dissonância da obra em relação à produção literária de então: um "descaso da modernidade como moda dominante" e a opção por uma "inactualidade que é a matéria constitutiva do seu discurso", ou seja, a história condiz com a matéria que a entretece". ${ }^{14}$ Para Vecchi, o deslocamento estético do romance, as figuras retóricas de contraste que marcam a narrativa (como inversões e quiasmos) e a ambivalência na representação - com descrições detalhadas ao lado de uma deliberada estratégia de omissões que provocam o leitor - inscreveriam a obra no Modernismo em uma condição de exceção, uma vez que, nas palavras do crítico, "o autor faz da desmontagem crítica seu princípio de construção latente"15. Proporcionar ao leitor uma experiência daquilo que é narrado estendendo-Ihe os sentimentos vivenciados pelos personagens seria um traço pós-moderno por excelência.

\begin{abstract}
Se quisermos então sintetizar com uma figura o mal-estar que se conjuga com a leitura - e que se prorroga também após a leitura - poderíamos dizer que se trataria de algo bem barroco, modernamente barroco. Sem Modernismo, não haveria $A$ menina morta, ainda que o romance, com um gesto ciente, se subtraia aos clichés modernistas. É uma relação de exceção que une, como figura extrema, o romance corneliano ao Modernismo: incluí-lo através da sua exclusão. Uma definição, esta, congruente no plano da filosofia política com o estado de exceção, justamente.
\end{abstract}

\footnotetext{
${ }^{13}$ RUFINONI, Simone Rossinetti. "Realismo e introspecção no romance de Cornélio Penna”. In: Literatura e Sociedade: Departamento de Teoria Literária e Literatura Comparada/USP, São Paulo, n. 14(2), 2010, p. 121.

${ }^{14}$ VECCHI, Roberto. “Autópsia da casa-grande”. In: PENNA, Cornélio. A menina morta. Posfácio. Lisboa: Cotovia, 2006. p.533.

${ }^{15}$ Idem. Ibidem. p.533.
} 
Figura barroca e também trágica, que deixa exposto um conflito: A menina morta coloca-se além - ou atrás - do Modernismo, mas através dum pensamento crítico que o próprio Modernismo funda. Forma e conteúdo combinam-se numa amálgama tão densa que agita fantasmas, exibe fraturas, desencadeia mal-estares. ${ }^{16}$

Mas para além do deslocamento estético do romance, um aspecto importante que se evidencia na obra é que ele não se alinha a qualquer registro formal, sendo a convergência de diferentes linhas ficcionais uma de suas características.

A atmosfera de angústia, reforçada por uma narrativa sombria e pelos jogos de luz e sombra, assim como os enigmas presentes na trama já foram motivo de aproximação com o romance gótico por parte da crítica.

Em estudo de 1976 sobre a obra de Cornélio Penna, Luiz Costa Lima ${ }^{17}$ sugere esta aproximação ao analisar o fantasma e o vampiro como figuras cujos traços remeteriam a alguns personagens de $A$ menina morta, de acordo com a interpretação que faz calcada nos dois eixos sobre os quais se estruturaria o romance, quais sejam, o caminho masculino que leva à Corte e, portanto, à civilização, e o feminino que leva à clareira da mata, ou seja, à natureza. Embora em edição posterior da obra ${ }^{18}$ a referida passagem tenha sido suprimida, mantém-se a análise das figuras fantasmais que a acompanha.

José Guilherme Merquior também menciona de passagem a filiação do autor ao gótico, referindo-se ao seu primeiro romance: "Na novelística de Cornélio Penna (Fronteira 1936), a atmosfera 'gótica' à Julien Green se apoia numa técnica e numa linguagem lacônica cuja alta poesia nada cede ao despojamento do lirismo" dos primeiros modernistas no Brasil $^{19}$.

\footnotetext{
${ }^{16}$ Idem. Ibidem. p.533.

17 LIMA, Luiz Costa. A perversão do trapezista. Rio de Janeiro: Imago, 1976. p. 56.

Para ele, "Pensar que A menina morta é de 1954 é de difícil entendimento, pela absoluta falta de contato que o romance mostra com a produção imediatamente anterior. Se formos então adeptos da teoria do desvio, atualmente difundida pelo conhecimento retardado dos formalistas russos, deveremos tomar Cornélio como o raro epígono de alguma corrente precedente - do romance gótico, talvez, misturado a Camilo Castelo Branco".

18 Idem. O romance de Cornélio Penna. 2ạ.ed. revista e modificada. Belo Horizonte: UFMG, 2005.

${ }^{19}$ MERQUIOR, José Guilherme. O modernismo brasileiro (esquema). Trad. Hilda Merquior. In: O Fantasma romântico e outros ensaios. Petrópolis:Vozes, 1980.p.129.
} 
Já Josalba Fabiana dos Santos defende que o romance de 1954 encena uma paródia do gótico que, como duplo ou fantasma de outro texto, em uma narrativa fantasmal ${ }^{20}$, reproduziria na forma elementos de seu conteúdo. "A paródia é um duplo ou um fantasma de outro texto; a paródia é de um texto que já "morreu" ou que está esquecido e que revive por meio do seu duplo ou fantasma"21.

Se tomarmos a definição primeira de paródia, temos que esta seria uma imitação estilística de um texto literário, autor ou tradição com efeito cômico²2.

O conceito tem sido objeto de ampla discussão e enquanto "citação crítica da linguagem literária performada com efeito cômico" ${ }^{23}$, ou como "recurso estilístico que deforma o discurso com o qual dialoga colocando em situação de cômico o texto que parodia", tem sido contestado por autores como Linda Hutcheon, que serve de parâmetro ao estudo da pesquisadora. Esta define paródia como uma relação formal ou estrutural entre dois textos, desconsiderando o cômico, mas admitindo a ironia como um aspecto da sua caracterização: “A paródia é pois, na sua irônica 'transcontextualização' e inversão, repetição com diferença. Está implícita uma distanciação crítica entre o texto em fundo a ser parodiado e a nova obra que incorpora, distância geralmente assinalada pela ironia."24

Haroldo de Campos ao conceber a paródia como "canto paralelo" aproxima-se do conceito de Hutcheon, e defende "um conceito amplo de paródia, também etimológico, despido de intencionalidade cômico-burlesca e armado, antes, de um distanciamento crítico-

\footnotetext{
${ }^{20}$ Termo atribuído por Luiz Costa Lima à narrativa, e incorporado ao texto "O Romance Gótico e a Obra de Cornélio Penna" também de SANTOS, Josalba Fabiana dos. XI Congresso Internacional da ABRALIC. 13 a 17 de julho de 2008. p.6.

${ }^{21}$ Cf. SANTOS, Josalba Fabiana dos. "A paródia como fantasma". In: Revista Brasileira de Literatura Comparada, n.14, 2009. p.237. Disponível em: <http://revista.abralic.org.br/index.php/revista/article/view/222/226>. Acesso: 10/10/2017.

22 Cf. E-dicionário de termos literários de Carlos Ceia. Disponível em: <http://edtl.fcsh.unl.pt/businessdirectory/6494/parodia/> Acesso: 27/03/2017. “Em definição simples, a paródia, enquanto termo literário, refere-se ao processo de imitação textual com intenção de produzir um efeito de cómico. A forma como se processa essa imitação, a motivação para o acto imitativo e as consequências esperadas para esse acto determinam a natureza literária da paródia."

${ }^{23}$ ROSE, Margareth. Apud HUTCHEON, Linda. "Uma Teoria da Paródia”. In: Ensinamento das formas de arte do século XX. Tradução Teresa Louro Pérez. Lisboa: Edições 70, 1989.

${ }^{24}$ HUTCHEON, Linda. “Uma Teoria da Paródia”. In: Ensinamento das formas de arte do século XX. Tradução Teresa Louro Pérez. Lisboa: Edições 70, 1989. p.48.
} 
irônico" 25 . No entanto, embora a obra estabeleça um diálogo com essa forma literária, não me parece que este se dê através da paródia, até por não ser esse recurso da natureza do texto.

Além da paródia, que Santos aponta ter sido uma das conquistas das vanguardas ${ }^{26}$, a autora defende ainda que, ao parodiar um gênero da cultura de massa, Cornélio Penna estaria problematizando a ideia de tradição literária, constituindo-se assim em um escritor do seu tempo ou até além do seu tempo.

Importante observar que a preocupação em sustentar a modernidade do romance transparece não apenas no ensaio acima referido, como em grande parte da crítica de Cornélio Penna, e parece indicar um modo de fazer frente ao desconforto com as obras que fogem aos procedimentos modernistas. ${ }^{27}$

Por outro lado, a retomada de formas tradicionais de que o autor faz uso é muitas vezes atribuída a um anacronismo da obra associado ao simples desejo de volta ao passado e, nesse sentido, uma manifestação necessariamente regressiva.

$\mathrm{Na}$ tentativa de dissolver a polaridade reducionista que opõe vanguarda e contravanguarda (ou retaguarda, no sentido próprio de oposição à vanguarda) segundo os termos de William Marx, ou modernos e antimodernos nos de Compagnon, se impôs uma reflexão por parte da crítica mais recente sobre os retrocessos e as continuidades da tradição que se inscrevem nas margens da teleologia geralmente aceita.

William Marx, ao propor uma reavaliação das contravanguardas das primeiras décadas do século XX na França, chama atenção para o risco de se negligenciarem obras que se desenvolvem em paralelo às das vanguardas, e que se caracterizam pela continuidade, ou

\footnotetext{
${ }^{25}$ Haroldo de Campos discute o conceito de paródia na introdução crítica a Oswald de Andrade - Trechos escolhidos. Rio de Janeiro: Agir, "Nossos Clássicos", 1967 que retoma no ensaio A Escritura Mefistotélica. In: Deus e o Diabo no Fausto de Goethe. São Paulo: Perspectiva, 2005. p.73 a 75.

${ }^{26}$ Cf. SANTOS, Josalba Fabiana dos. Ibidem. p. 236

27 Já na apresentação, a autora afirma: A menina morta, de Cornélio Penna, é um romance que sempre desnorteou a crítica brasileira pelo seu aspecto aparentemente anacrônico. No entanto, um estudo mais cuidadoso demonstrará que esse livro publicado em 1954 dialoga sobremaneira com o seu momento histórico e estético, pois se apresenta como uma paródia do tradicional romance gótico inglês. Vale lembrar também que a paródia foi um recurso utilizado à exaustão pelo modernismo."
}

Cf. SANTOS, Josalba Fabiana dos. Ibidem. pp. 227-245. 
mesmo retorno a formas passadas. Para ele, considerar tais obras anacrônicas por não aderirem às propostas vanguardistas, não apenas colocaria na sombra obras de relevo, como criaria pontos cegos na história das ideias e das artes. ${ }^{28}$

A análise do professor e crítico Vagner Camillo sobre a retomada de formas prémodernistas que configurou uma tendência da Lírica no período que se estende da Segunda Guerra mundial a meados dos anos 50, parece iluminar essa discussão, no sentido de provocar a indagação sobre o sentido do recuo estético da obra. Ao examinar as linhas gerais dessa tendência, que se verificou tanto em poetas modernistas já consagrados como nos poetas que surgiam então, e que resultou em obras com níveis de realização estética desiguais, ele investiga as motivações e os sentidos dessa retomada. A partir dos poemas mais significativas dos autores e sem perder de vista a especificidade de cada um deles, aponta como esse movimento que, se em alguns casos se justificou por um projeto restaurador e regressivo, em outros refletiu, por exemplo, uma reação à rotinização das experimentações das vanguardas, seja pelo desencanto com a dissolução dos ideais que elas sustentavam, seja por uma problematização da questão do envelhecimento do moderno. ${ }^{29}$

A meu ver, a recusa deliberada de Penna em aderir a certos procedimentos do movimento modernista suscita questões, em um momento em que esse projeto já havia inclusive se esgotado e suas formas assimiladas. Apesar de remeter ao romance oitocentista, não se constitui como tal, apresentando um hibridismo na forma e sugerindo um sentido na obra que deve ser, na medida do possível, decifrado.

Mas retomando a discussão do gótico, e se considerarmos, de acordo com a pesquisadora Sandra Vasconcelos, que o movimento literário que se convencionou chamar de gótico constitui-se como uma forma híbrida desde a sua concepção ${ }^{30}$ e se manifesta de maneira diferenciada mesmo entre autores que produziram em um determinado contexto ou época, a maior ou menor proximidade ao real, as explicações mais ou menos racionais, os

\footnotetext{
${ }^{28}$ Cf. MARX, William. "Penser les arrière-gardes". In: (org,). Les arrière-gardes au XXe siècle. pp. 5 -19.

${ }^{29}$ CAMILO, Vagner. A modernidade entre tapumes: da lírica social à conversão neoclássica na poesia brasileira moderna. São Paulo; USP (2017).

${ }^{30}$ VASCONCELOS, Sandra Guardini. Dez lições sobre o romance inglês. São Paulo: Boitempo, 2000. p.128.
} 
detalhes macabros ou a explicitação de cenas de violência e atmosferas de terror podem apresentar-se em diferentes graus, e muitas vezes serem apenas sugeridos.

A história literária tendeu a obliterar a heterogeneidade e a diversidade e a tratar os romances góticos como um corpo homogêneo de textos, reduzindo-os na prática a um conjunto de características comuns: a ênfase na representação do terrível, a insistência nos cenários arcaicos, o uso do sobrenatural, as personagens estereotipadas, o uso da técnica de suspense ${ }^{31}$.

Assim é que, se o romance se aproxima do Gótico ao retroceder a narrativa no tempo, ao colocar em cena temas característicos do movimento como a morte real e simbólica, e ao utilizar procedimentos próprios deste, tais como a atmosfera nebulosa, as imagens fantasmáticas ou o sentimento de ameaça constante que acomete os personagens, o faz em chave diversa da literatura gótica. A violência e a crueldade não estão a serviço da virtude, mas se realizam através da instituição da escravidão, determinante na forma como se consolidam as relações sociais no Brasil. Não cria o suspense, nem se pretende como literatura do medo, com fim moralizante ou exemplar, já que não recompensa as virtudes ou devolve o leitor "são e salvo, ao mundo da razão, da moralidade e da felicidade doméstica que caracterizava grande parte da ficção realista do século XVIII"32. Ao identificar as personagens a fantasmas ou espectros, não recorre ao irracional ou sobrenatural, mas projeta no mundo objetivo os medos e culpas destes, indicando como eles inexistem como indivíduos autônomos. O terror que retrata é o terror em que vivem os personagens, presos à estrutura patriarcal, e ensimesmados em seus próprios dramas. A atmosfera ameaçadora, os ruídos que sobressaltam, a percepção distorcida dos objetos, concretizam os sentimentos dos personagens, seus medos e angústias, e não é algo que lhes é exterior. Diferentemente do que acontece com o romance gótico, o romance tampouco representa as tensões que a sociedade de então produziu de si mesma desafiando o racionalismo e afirmando-se como literatura da "desrazão". No entanto, e do mesmo modo que no gótico, o espaço ocupa posição de destaque, e tanto a casa como a geografia da região com suas montanhas e matas, ao mesmo tempo ecoam e reforçam a hostilidade do ambiente.

\footnotetext{
${ }^{31}$ VASCONCELOS, Sandra Guardini. Ibidem. p.125. Não apenas a citação, mas grande parte da exposição do tema baseou-se no ensaio referido.

32 Idem Ibidem. p.131.
} 
Considerando a definição de Todorov, podemos pensar também nas relações que o romance estabelece com a narrativa fantástica, uma vez que para ele, "o fantástico é a hesitação experimentada por um ser que não conhece senão as leis naturais, diante de um acontecimento aparentemente sobrenatural" ${ }^{33}$. O conceito, que se define ainda segundo o teórico russo, no limite entre o estranho e o maravilhoso, condiciona-se à hesitação do leitor, pois implica uma integração deste ao mundo dos personagens ${ }^{34}$.

Algumas passagens poderiam ser ilustrativas desse procedimento, como quando Celestina vai visitar Dadade, antiga ama do Comendador, já que provocam essa hesitação ao sugerir a presença de forças demoníacas na fazenda. A narrativa deixa em suspenso o limite entre o real e o irreal, pois em meio a uma longa história, a velha escrava de repente diz:

Eu já disse muitas vezes Nhangana, que não pusessem cabras amarradas no poste aí na varanda em frente de meu quarto, mas esses negros não me obedecem! A senhora não quer fazer essa caridade para o sossego da negra velha, de falar com o meu Senhor que mande tirar esse bode preto que botam sempre aí? Olhe como ele bate com os pés no chão e funga tão alto. Eu chego a ter medo... ${ }^{35}$

Celestina levanta-se, e embora não veja nenhum animal, pede às escravas que não permitam mais amarrar qualquer bicho naquela coluna, pois incomoda a doente. Ao repetir o que ouvira à Dadade, que não era permitido que as cabras entrassem no quadrado, ela lhe responde:

“- Perdoe, Nhanhã... não é cabra não ... a negra velha sabe que é outra coisa!"36

Quatro capítulos adiante, depois que Carlota ouve gemidos e vê escravos no tronco, tomando contato pela primeira vez com os suplícios a que eram submetidos, ela corre para casa.

\footnotetext{
33 « Le fantastique, c'est l'hésitation éprouvée par un être qui ne connaît que les lois naturelles, face à un événement en apparence surnaturel.» TODOROV, Tzvetan. Introduction à la littérature fantastique. Paris : Éditions du Seuil. S/D. p. 29

34 « Le fantastique implique donc une intégration du lecteur au monde des personnages :il se définit par la perception ambiguë qu'a le lecteur même des événements rapportés. (...) L’hésitation du lecteur est donc la première condition du fantastique. » Idem Ibidem. p.35/36

35 PENNA, Cornélio. Ibidem. p.1208

${ }^{36}$ PENNA, Cornélio. Ibidem. p.1209
} 
Mas ao passar junto das colunas sustentantes da varanda, espantou o animal deitado junto a uma delas, e ele se levantou espavorido, tentando romper a corda que o prendia. Carlota ainda teve tempo de distinguir grande bode preto, inexplicavelmente deixado prisioneiro ali... ${ }^{37}$

A narrativa não esclarece, portanto, a existência ou não do animal, referido anteriormente como presença maléfica a perturbar a paz da fazenda, e provoca a ambiguidade própria ao fantástico.

Há ainda uma alusão direta ao poema O Corvo de Edgar Allan Poe cuja obra, na sua maioria ligada ao estranho, segundo a tipologia proposta por Todorov, inclui alguns contos fantásticos. Refiro-me à passagem em que Carlota sonha que a chamam insistentemente, e então ouve batidas na janela. Ao aproximar-se, vê apenas uma tênue neblina que tornava tudo irreal até perceber que as batidas são das bicadas de um pássaro que sacode as asas agitado, ansioso por transmitir alguma mensagem. Ela se lembra da angústia sentida com o chamado durante o sono "e estremece ao lembrar-se das histórias velhas de Joviana onde os presságios, os sinais do além precediam sempre a morte de suas heroínas". O sentimento de ameaça de algo indefinido, terrível e iminente, assim como o tom sombrio, melancólico está presente em ambos os textos. No entanto, diferentemente do protagonista do poema, que vence o medo e abre a janela para o visitante enfrentando a indagação sobre a morte, ela fica paralisada, tomada de angústia e pavor. ${ }^{38}$

Importante lembrar que E. A. Poe, embora influenciado pelo gótico, pela força de invocação e sugestão das imagens produz uma obra de fundamental importância na história do Simbolismo, movimento com o qual o romance estabelece estreita ligação.

A relação da obra com a matriz simbolista que, inclusive, atravessa o Modernismo, também já foi apontada por parte da crítica. Andrade Muricy identifica tendências simbolistas na forma com que o autor afirma a dor da existência, o interesse pelo mistério e a transcendência espiritual através de uma prosa de contorno subjetivo, intimista. Luciana

\footnotetext{
37 PENNA, Cornélio. Ibidem. p.1226

${ }^{38}$ A intertextualidade da passagem acima com o poema de Poe já foi feita por Irene Jeanete Gilberto Simões em Oficina de artista - a linguagem dos romances de Cornélio Penna, 1990, 237 fl. Tese (Doutorado em Teoria Literária e Literatura Comparada), FFLCH, Universidade de São Paulo, São Paulo, 1990, em que a pesquisadora identifica "imagens do bestiário" recorrentes na obra de Cornélio Penna, que se desdobram continuamente, como signos representativos dos personagens e da representação do mundo. Ao tratar do pássaro, uma das figuras dominantes desse bestiário, aponta como essa evoca uma pluralidade de sentidos, e está presente em toda a obra do autor. p. $85-106$.
} 
Stegagno Picchio, no mesmo sentido, faz uma aproximação da obra a alguns simbolistas, com quem identifica "o estudo sutil de estados de alma; o clima de inefabilidade, de impasse existencial e de perplexidade angustiosa" ${ }^{39}$.

A mistura de imagens, as comparações incomuns, o uso da sinestesia para traduzir sensações, uma objetividade que se funde à subjetividade ${ }^{40}$, uma ação esvaziada que sugere mais do que diz, tudo somado a uma linguagem que recorre a elementos pictóricos sem, contudo, abrir mão da representação da realidade, apontam para alguns dos procedimentos que caracterizam essa aproximação, conforme a cena dos doces que são levados à mesa.

A cozinheira fora buscar as escumadeiras para apanhar os detritos que subiam dançando à superfície da calda, onde já se desenhavam largas borbulhas escuras muito reluzentes, opalizadas com as cambiantes da luz e cortadas de centelhas de prata viva. (...) Ainda apanhavam com as grossas colheres a escuma vinda à superfície, e as negrinhas da copa, que tinham já levado as grandes travessas azuis de louça da Índia com as iguarias suculentas que deviam constituir o almoço dos senhores, carregavam agora para a sala grandes bandejas, com as tigelas de porcelana inglesa em desenhos multicolores representando cenas do campo, repletas até a borda dos doces em calda, onde os marmelos sanguíneos nadavam no açúcar denso, os figos sombrios como peixes das grandes profundidades estremeciam amontoados no centro envoltos em seu xarope de mel e as ameixas negras nacaradas vindas da França pareciam de veludo de seda... queijos-do-reino e de Holanda completavam a riqueza do bodo uns em fatias com suas cores vivas, de amarelo oriental, cercadas pela fímbria rubra, outros em verdadeiras montanhas no centro dos pratos flamengos, ralados cuidadosamente, a fim de serem com eles aproveitadas as caldas diversas ${ }^{41}$

Além de flertar com uma multiplicidade de linhagens, como o romance realista, o neobarroco, o gótico, o fantástico, e o Simbolismo, o autor parece também problematizar, neste romance de 1954, através da fusão de realismo e introversão, a polarização proposta pela historiografia da chamada literatura de 30 , que divide a produção da época em obras marcadas por preocupações de ordem social e outras de tendência intimista ou psicológica e que refletiam, de certa forma, a polarização ideológica que tinha lugar então.

Por um lado, representa de modo fiel os aspectos sociais e culturais das fazendas de café do vale do Paraíba e a estrutura patriarcal então vigente, evidenciando inclusive suas formas de sociabilidade, sugerindo que o horizonte da obra é histórico-social. Por outro,

\footnotetext{
39 PICCHIO, Luciana Stegagno. História da literatura brasileira. Rio de Janeiro: Nova Aguilar.1997. pp.430-431.

${ }^{40}$ WILSON, Edmund. O Castelo de Axel - Estudo sobre a literatura imaginativa de 1870 a 1930. Trad. José Paulo Paes. 2.ed. São Paulo: Companhia das Letras, 2004.
}

41 PENNA, Cornélio. Ibidem. p.921 
constrói uma narrativa marcada pela sondagem interior dos personagens e pela subjetivação de seus conflitos. O mundo que aprisiona e a dor que caracteriza os personagens parecem ultrapassar, no entanto, as questões objetivas que os envolvem.

O romance, portanto, rompe com a classificação que distingue romance social e romance psicológico, opera com categorias deslocadas da crítica e ainda dialoga com diferentes vertentes da literatura, como a tradição regionalista da literatura brasileira ${ }^{42}$.

Se partirmos do ponto de vista de José Maurício Gomes de Almeida para quem "para ser regional uma obra de arte não somente tem que ser localizada numa região, senão também deve tirar sua substância desse local" ${ }^{43}$, podemos considerar que $A$ menina morta integra, em parte, essa vertente da literatura. ${ }^{44}$

O autor elege a região fronteiriça entre as então províncias do Rio de Janeiro e Minas Gerais não apenas como palco para a ambientação da narrativa, mas também como tema do romance, em que tanto os personagens estão em profunda relação com a realidade socioeconômica da região, como a natureza e a própria geografia da região com suas montanhas e matas, compõem a narrativa.

Enquanto os engenhos de açúcar e as fazendas de cacau foram amplamente retratados pela literatura regionalista do Nordeste, que entre 1930 e 1945 se afirma como denúncia das desigualdades e das contradições de um país que de um lado se industrializava e se pretendia urbano e moderno, e de outro guardava traços arcaicos, as fazendas de café do Sul não tiveram a mesma representação.

Gilda de Mello e Souza, em ensaio de 1956 em que analisa como o teatro no Sul se antecipava aos estudos sociais e se encarregava da tarefa que havia sido realizada pelo

\footnotetext{
${ }^{42}$ RUFINONI, Simone R. (assim como Luís Bueno - verificar), questionam a oposição entre romance social e romance intimista proposta por parte da crítica.

${ }^{43}$ ALMEIDA, José Maurício Gomes de. A Tradição Regionalista no Romance Brasileiro. ..... p.177

${ }^{44}$ José Aderaldo Castello chega a identificar a obra de Penna como uma das vertentes da ficção "regionalista" que, distribuída em regiões naturais e culturais definidas, esboçam uma visão heterogênea do país. "Incluindoa no que ele denomina ciclo do Sul, em que se destacam São Paulo - compreendido aí o Triângulo Mineiro e especificamente o Vale do Paraíba da cultura do café - e o Rio Grande do Sul", ela comporia um regionalismo não mais documental, mas voltado para a análise das estruturas da sociedade rural brasileira. "Um regionalismo cultural que deixa de ser restritivo, particularizador e descritivo, para desnudar o sentido mais profundo da "unidade na diversidade". CASTELLO, José Aderaldo. A literatura brasileira: Origens e Unidade. Vol. II. São Paulo: Edusp 1a reimpressão 2004.p.369.
} 
romance no Nordeste, formula alguns motivos que poderiam explicar esse fenômeno. Para além do fato de talvez o romance não ser o gênero adequado para refletir uma realidade de tal modo facetada, pois ligado a uma tradição linear e assim pouco habilitado a uma sondagem mais complexa, ela busca na forma como se operou a crise da sociedade patriarcal nas respectivas regiões a razão da diversidade da sua representação. Nesse sentido, o processo de urbanização e de industrialização do Sul do país, que se deu simultaneamente à decadência da economia rural exportadora, teria dificultado a própria representação da memória, diferentemente do que havia ocorrido no Nordeste.

\begin{abstract}
A perda de prestígio do fazendeiro se cruzava com a ascensão econômica e social do imigrante. Presenciava-se, sem fôlego, uma substituição simétrica de estilos de vida e não o lento desaparecimento de um mundo cuja agonia se pudesse acompanhar com lucidez. Por outro lado, a competição que logo se estabeleceu não poupava ninguém. Dilacerado entre as imposições do presente e a saudade do passado, o sobrevivente nostálgico escorregava sem sentir para o emprego modesto da grande cidade. (...) Agentes do correio, funcionários de banco, escriturários subalternos, chefes de seção, todos guardavam no anonimato da grande cidade a lembrança viva da ascendência ilustre, formando a numerosa galeria dos vencidos. Do naufrágio iriam salvar-se apenas os "viajantes sem bagagem", isto é, aqueles que perdendo a memória do grupo puderam acomodar-se às oportunidades novas das profissões liberais e da técnica. E assim, o equilíbrio social do Sul e o seu progresso econômico se deram em detrimento da literatura. ${ }^{45}$
\end{abstract}

Embora esteja tratando da representação de outro momento, ou seja, da crise do café que se verifica em 1929, me parece que a análise pode ser ampliada para a reduzida representação que se observa na literatura das fazendas de café.

José Maurício Gomes de Almeida aponta ainda outros fatores que ajudam a explicar a preponderância na representação da decadência das fazendas de cacau e nos engenhos de cana de açúcar sobre as propriedades do Sul na ficção regionalista, como o breve período que estas ocuparam a região do vale do Paraíba e sua proximidade com a Corte, que teriam tornado ainda mais difícil a criação de "formas originais de cultura".

Alencar já havia observado certas particularidades na região do vale do Paraíba, em que se cristaliza uma determinada cultura influenciada pelos padrões de consumo da Corte. No entanto, trata da influência da nova cidade no ambiente rural ${ }^{46} \mathrm{com}$ a preocupação

\footnotetext{
${ }^{45}$ SOUZA, Gilda de Mello e. Teatro ao Sul. In: Exercícios de Leitura - $\mathrm{O}$ baile das quatro artes. São Paulo: Duas Cidades, 1980.pp. 109-116.

${ }^{46}$ Ao refletir sobre o conjunto da sua obra dentro do panorama da literatura brasileira, Alencar afirma: "Onde não se propaga com rapidez a luz da civilização, que de repente cambia a cor local, encontra-se ainda em sua pureza original, sem mescla, esse viver singelo de nossos pais, tradições, costumes e linguagem, com um
} 
voltada para a destruição de valores tradicionais, tendo em vista, como exemplo, o contraste entre as personagens Adélia e Alice em $O$ tronco do ipê. A superioridade desta "menina da roça", "a menina brasileira, a moça criada no seio da família, des de muito cedo habituada à lida doméstica e preparada para ser uma perfeita dona de casa", que restabelece os costumes da fazenda como na comemoração da festa de Natal, faz um contraponto à primeira, menina citadina, nas palavras do narrador, "tipo raro então, e hoje muito comum, de certos costumes de importação; era a mocinha de arrebicadas à francesa, cuidando unicamente de modas e do toucador" 47 .

Esta "tensão entre o espírito conterrâneo e a invasão estrangeira" ${ }^{48}$ presente nas obras de Alencar tanto em seus romances de fazenda como nos romances urbanos não constitui, no entanto, o foco de $A$ menina morta. Penna orienta suas preocupações para aspectos de ordem mais existencial e de origem da sociabilidade brasileira através da recriação do mundo da fazenda, em que parece indicar a formação da elite a partir das famílias cujas riquezas são oriundas do café.

Sabemos que, se a cana-de-açúcar foi a base de sustentação da economia da Colônia, o café foi o sustentáculo da economia do Império. As lavouras do Vale do Paraíba constituíram-se na mais importante área de produção cafeeira do país até 1880 , apesar do avanço em direção ao chamado Oeste paulista desde a década anterior. A riqueza oriunda das exportações foi transformando aos poucos a região.

A região identificou-se, no período monárquico, com o símbolo de grandeza social e econômica, à base da prosperidade cafeeira.(...)

Nessa área assumiu contornos próprios em sua primeira expressão a paisagem típica das fazendas de café. De início, próxima à corrente fluvial, a sede tosca, simples rancho coberto de sapé, não distante dos abrigos dos negros. (...) Depois de alguns anos o pomar, a horta e, mais tarde, a residência senhorial com seus jardins, os salões imensos e as diminutas alcovas, sempre pródiga em hospitalidade. Ela se orna com o decorrer dos

sainête todo brasileiro. Há, não somente no país, como nas grandes cidades, até mesmo na corte, desses recantos, que guardam intacto, ou quase, o passado. O Tronco do Ipê, o Til e o Gaúcho, vieram dali; embora, no primeiro sobretudo, se note já, devido à proximidade da corte e à data mais recente, a influência da nova cidade, que de dia em dia se modifica e se repassa do espírito forasteiro". In: José de Alencar. Benção paterna Prefácio a Sonhos d'ouro.

${ }^{47}$ ALENCAR, José de. O tronco do ipê. 12ª ed. São Paulo: Melhoramentos, 1965, p.148.

${ }^{48}$ ALENCAR, José. "Bênção paterna". In: Obra completa. Rio de Janeiro: Aguilar, 1959. Vol..I. p.699. 
anos, com os espelhos de moldura dourada, os lustres de cristal, os serviços de porcelana e as camas francesas com cortinado, a prataria fina, os móveis pesados de madeira de lei. Por volta de 1860, a figura do fazendeiro de café que provinha sobretudo de mineradores decadentes, pequenos comerciantes e donos de terras, havia se definido como um novo tipo social. Desenvolvia-se o patriarcado do café, como sucedera com os senhores de engenho; projetava-se nos quadros políticos da Monarquia e afidalgava-se com os títulos nobiliárquicos derramados em profusão pelo Imperador sobre as grandes fortunas alicerçadas pela economia cafeeira. A hierarquia conferiu-lhe refinamento de trato, maneiras aristocráticas condignas. Ao se incorporarem à nobreza do Império, os fazendeiros paulistas mantinham uma tradição já firmada quanto à hierarquia social do grande fazendeiro do cafét9.

Conforme Luiz Felipe de Alencastro, soma-se ao rápido e intenso processo de acumulação dos cafeicultores o aumento no fluxo de comércio externo brasileiro a partir de 1850.

A corte, as embaixadas estrangeiras, o comércio marítimo, as escalas contínuas de viajantes que cruzam o Atlântico Sul, a chegada de profissionais europeus, engendram no Rio de Janeiro um mercado de hábitos de consumo relativamente europeizados. (...). Além do mais, há uma particularidade da economia brasileira que deve ser explicada para se entender o afluxo de importados - bens de consumo e supérfluos - que transforma a vida social da corte e do Império em meados do século. (...) Cessado o tráfico, ocorre um retorno das divisas obtidas nas vendas de produtos de exportação e até então reservadas para financiar a compra de africanos ${ }^{50}$.

A inauguração de uma linha regular de navio a vapor entre a Inglaterra e o Rio de Janeiro em 1851 intensifica ainda este comércio, cujo reflexo é bem retratado no romance, através dos produtos consumidos pelos moradores tais como joias, sabonetes e rendas franceses, sedas da China, serviços de louça das Índias, garrafas de cristal, bandejas de prata ou alimentos como doces secos, toletes de chocolate, passas, ameixas, nozes, avelãs e amêndoas. Da mesma forma, a mobília escura de madeira de lei, o lampião de querosene, os cavalos árabes importados, os jornais ou os periódicos a que têm acesso como o Mode Illustrée entre outros, também indicam as pretensões aristocráticas dos chamados barões do café.

\footnotetext{
${ }^{49}$ CANABRAVA, Alice P. "A grande lavoura". In: História da Civilização Brasileira. Vol. 6. Declínio e queda do Império. pp. 109-110.

${ }^{50}$ ALENCASTRO, Luiz Felipe de. Vida Privada e Ordem Privada no Império. In: História da vida privada no BrasilImpério: a corte e a modernidade nacional. p.37.
} 
Alencastro aponta ainda como "o estabelecimento do Segundo Império na França (1852-70) dá ao Segundo Reinado um novo tom de modernidade e confirma o francesismo das elites brasileiras". Através de folhetins, operetas e romances difundia-se, para além da moda parisiense, "uma representação da sociedade rural francesa que aparecia como um paradigma de civilidade para a sociedade tropical e escravagista dos campos do Império". ${ }^{51}$ É interessante observar que a publicação que o pesquisador elenca como exemplo de articulação entre os costumes franceses e a moda local é uma das publicações recebidas e consultadas pelas personagens do Grotão: o Jornal das Famílias ${ }^{52}$.

Se esse consumo também marcou outras regiões do país, é junto aos fazendeiros da zona cafeeira em torno da Bacia do Rio Paraíba do Sul na província do Rio de Janeiro que, seja em função da proximidade da corte e do poder de compra oriundo da comercialização do café (cujo preço no mercado internacional controlava, por deter o controle sobre grande parte da oferta mundial do produto), seja pelo seu enriquecimento rápido e vertiginoso, se formou uma elite senhorial integrada na ordem econômica mundial, que buscava incorporar valores, hábitos e consumo compatíveis com sua trajetória ascensional, e que figuravam não apenas como sinal de riqueza, mas de distinção social.

Refinando seus hábitos, transformando suas moradias e recebendo títulos concedidos pelo Império, os proprietários atribuíam-se ares de nobreza, como bem representado no romance pelo comportamento e pelo modo como se apresentam o Comendador e Da. Mariana, com joias e roupas pesadas e impróprias para o campo. Não podemos esquecer que o patriarca do Grotão faz seus estudos na Europa, e é o responsável pela renovação e transformação da sede da fazenda.

\footnotetext{
${ }^{51}$ Idem. Ibidem. p.43

52 Publicado entre 1863 e 1878, o Jornal das Famílias com enfoque literário e voltado exclusivamente para o público feminino, teve como um de seus colaboradores Machado de Assis que ali publica muitos dos seus primeiros contos. Um trecho do editorial do primeiro número do periódico explicita o alcance do projeto: "Mais do que nunca dobraremos os nossos zelos na escolha dos artigos que havemos de publicar, preferindo sempre os que mais importarem ao país, à economia doméstica, à instrução moral e utilidade das famílias". Cf. Jornal das Famílias, tomo 1, jan. 1863, p. 02-03 apud Luiz Jaison Crestani. A colaboração de Machado de Assis no Jornal das Famílias: subordinações e subversões. p.149.
}

O pesquisador, que contraria uma linhagem crítica que aponta como os rearranjos em matéria e forma reconfiguraram a obra do autor a partir de Memórias Póstumas de Brás Cubas, atribui a amenidade das histórias e sua estrutura folhetinesca, característica das leituras de entretenimento que configuram os contos da chamada 1a fase da sua produção, às disposições imediatas da sua circulação. 
A presença da governanta alemã também pode ser pensada como representação deste processo de individuação do "Sul", que se pautava no comportamento das elites europeias. Muito menos comum nos engenhos do Nordeste, as governantas ou preceptoras estrangeiras eram contratadas pelas famílias mais abastadas para se ocuparem da educação das crianças até a idade em que eram enviados aos colégios, em regime de internato. Importante lembrar, embora em chave diversa, a figura da fräulein em Amar, verbo intransitivo, assim como o depoimento da alemã Ina von Binzer que, sob o pseudônimo de "Ulla von Eck" escreve, como num diário a uma amiga, sobre as suas experiências como governanta e preceptora de duas famílias da elite do café entre 1881 e 1884 . Suas cartas, reunidas no romance epistolar Alegrias e Tristezas de uma Educadora Alemã, lançado em 1897 na Alemanha e publicado no Brasil em 1956, foi resenhado e comentado por Cornélio Penna, com o título "As cartas de Ulla". ${ }^{53}$ Reafirmando a fidelidade da narrativa, embora em um tom bem-humorado que pode se justificar por estar se dirigindo a uma amiga, podemos observar vários pontos de contato entre as reflexões da autora e as declarações de Da. Frau, governanta do Grotão, como nos excertos abaixo:

Aliás, essa atitude de superioridade, assumida até pelas próprias crianças, devido à escravidão aqui existente, apresenta geralmente um aspecto humorístico. ${ }^{54}$

Todo trabalho aqui é realizado pelos pretos, toda a riqueza é adquirida por mãos negras, porque o brasileiro não trabalha, e quando é pobre prefere viver como parasita em casa dos parentes e de amigos ricos, em vez de procurar ocupação honesta.

Todo o serviço doméstico é feito por pretos: é um cocheiro preto que nos conduz, uma preta quem nos serve, junto ao fogão o cozinheiro é preto e a escrava amamenta a criança branca... ${ }^{55}$

\footnotetext{
${ }^{53}$ MESSEDER, Luciana. Por uma contextualização sócio-histórica de A menina morta, de Cornélio Penna, 2006, 94fl. Dissertação (Mestrado em Literatura Brasileira), Letras, Universidade Estadual do Rio de Janeiro, Rio de Janeiro, 2006. p.28. Disponível em: <http://livros01.livrosgratis.com.br/cp150784.pdf> Acesso em: 21/11/2017.

Ao exemplificar as raras aparições de Cornélio Penna na imprensa, aponta uma resenha do autor de 1957 (16/03/57) em periódico não identificado, encontrado nos arquivos da Fundação Casa de Rui Barbosa. Tendo localizado o artigo para esta pesquisa no Correio da Manhã, indico o link da Biblioteca Nacional e dados para localização:

http://memoria.bn.br/DocReader/docreader.aspx?bib=089842_06\&pasta=ano\%20195\&pesq=Cornelio\%20Pen

a. | Loc.: 1957 edição 19623 p.9

${ }^{54}$ BINZER, Ina Von. Os meus romanos - alegrias e tristezas de uma educadora alemã no Brasil. 5ạ. Ed. São

Paulo: Paz e Terra, 1991. p.22.

55 Op.cit, p.34.
} 
Para entendermos as particularidades dessa elite em formação, talvez caiba colocar ainda que neste período os fazendeiros escravistas das novas áreas de produção, juntamente com as elites agrárias de outras regiões, negociantes e burocratas não apenas detêm o poder econômico, mas vão se constituindo como classe senhorial de forma articulada com a construção do Estado imperial, conforme aponta Ilmar Rohloff de Mattos. ${ }^{56}$

Figurando apenas indiretamente no romance, a cidade do Rio de Janeiro se apresenta em íntima relação com a cultura agrária da região ${ }^{57}$, diferentemente do que acontecerá posteriormente em São Paulo, cidade marcada pelo desenvolvimento da indústria e em que a presença do imigrante cria outra relação com o passado e com suas tradições. Embora em segundo plano, temos no romance a representação tanto da vinculação dessa elite com o poder, como é o caso do pai do pretendente de Carlota, também fazendeiro da região que ocupava o cargo de ministro do Império, como o do mundo dos negócios, em que os comissários desempenhavam o papel de intermediários entre os fazendeiros e os exportadores, além de atuarem como agentes de crédito ${ }^{58}$, tendo em vista a inexistência de crédito agrícola no país. Vemos também o caráter pessoal e nitidamente patriarcal que se estabeleciam entre esses últimos e os fazendeiros, como quando hospeda em sua casa o Comendador e o filho doentes, indicando uma sobreposição de relações pessoais às profissionais que não se limitará aos tempos do Império. ${ }^{59}$

Mas ao admitirmos a hipótese que Cornélio Penna dialoga com o romance regionalista, temos que considerar que ele acrescenta à análise social preocupações

\footnotetext{
${ }^{56}$ MATTOS, IImar Rohloff. O tempo saquarema. $\mathrm{O}$ autor analisa como, entre os últimos anos do período regencial até o início dos anos de 1860, diante do fracasso do projeto dos liberais, os saquaremas se ocupam da construção do Estado e lhe impõem uma direção, promovendo a expansão da classe que representavam e buscavam consolidar, assegurando a Ordem e difundindo a Civilização. Seu núcleo de ação era a Corte, ponto a partir do qual as estratégias de controle político-social do governo central se irradiavam em direção às demais províncias do Império.

${ }^{57}$ Esta dependência das cidades em relação aos domínios agrários foi apontada inicialmente por Sergio Buarque de Holanda em Raízes do Brasil, que observa ainda "como na ausência de uma burguesia urbana independente, os candidatos às funções novamente criadas recrutam-se entre indivíduos da mesma massa dos antigos senhores rurais, portadores de mentalidade e tendência características dessa classe", e carregam consigo a mentalidade e os preconceitos senhoriais. P.57.

${ }^{58}$ Cf. CANABRAVA, Alice P. Ibid. p.158.

${ }^{59}$ Importante lembrar que é em Raízes do Brasil, que o autor especifica o conceito de cordialidade na construção da identidade nacional, ao identificar como a sobreposição de relações pessoais às profissionais ou públicas trazem distorções de racionalidade e, como a indistinção entre a esfera pública e o privado constituise como empecilho na formação de uma sociedade urbana moderna.
} 
metafísicas e universalistas, numa tendência mais próxima do regionalismo pós 1945, cuja maior expressão é a obra de Guimarães Rosa, embora com enfoque diferente, pois esta tende ao intemporal e se aproxima do mito.

Voltando a Alencar, parece-me ainda que $A$ menina morta dialoga com uma tradição que vem deste autor romântico: a do romance fazendeiro, denominação que Antonio Candido conferiu a uma das vertentes do que ele chamou de Alencar dos adultos. "O tronco do ipê e Til inauguram o romance fazendeiro, a descrição da vida rural já marcada pelas influências urbanas". 60

Estes romances, juntamente com alguns dos romances urbanos de Alencar, não têm como núcleo a ação heroica e altissonante ou a ação sentimental, mas a revelação de personagens de maior densidade, e as relações humanas que estabelecem em função do ambiente em que estão inseridos.

\begin{abstract}
Mais importantes, todavia, do que os ambientes, são as relações humanas que estuda em função deles. Como em quase todo romancista de certa envergadura, há em Alencar um sociólogo implícito. Na maioria dos seus livros, o movimento narrativo ganha força graças aos problemas de desnivelamento nas posições sociais, que vão afetar a própria afetividade dos personagens. As posições sociais, por sua vez, estão ligadas ao nível econômico, que constitui preocupação central nos seus romances da cidade e da fazenda (...) e o conflito da alma dos protagonistas com as possibilidades materiais é básico no encaminhamento da ação ${ }^{61}$.
\end{abstract}

Cabe lembrar que $O$ tronco do ipê, de 1871, é ambientado em uma fazenda às margens do Paraíba, entre 1850 e 1858, quando seus proprietários vão para a Corte, e a fazenda entra em decadência. A ação de Til, publicado no mesmo ano, passa-se em 1846, mas retrocede até 1826, e tem lugar às margens do Rio Piracicaba, no interior do Estado de São Paulo, às

\footnotetext{
${ }^{60}$ CANDIDO. Antonio. "Os Três Alencares". In: Formação da literatura brasileira. 9ạ. ed. 2o..Vol. Belo Horizonte, Rio de Janeiro: Itatiaia, 2000, p. 201.

61 Idem, Ibidem. p.204.
} 
voltas de uma fazenda também de café ${ }^{62}$. É interessante observar que Alencar representa, através destas duas regiões, a própria trajetória do cultivo do produto ${ }^{63}$.

Na análise de Paula Barbosa Maciel sobre Til, a pesquisadora examina os aspectos formais do romance e discute as continuidades e as diferenças desse em relação à obra anterior do romancista. Como contraponto, ela elenca além de $O$ tronco do ipê, outros dois romances fazendeiros: A mocidade de Trajano, primeiro romance do Visconde de Taunay, também publicado em 1871, ambientado em uma fazenda de café escravista, também na Província de São Paulo, agora na região de Campinas, e o livro de Joaquim Manuel de Macedo, As Vítimas-Algozes: quadros da escravidão lançado dois anos antes, em que duas das três novelas são ambientadas em fazendas, que não contam, no entanto, com uma caracterização mais precisa. ${ }^{64}$

Regina M. A. Machado, por sua vez, concentra seus estudos no romance fazendeiro como gênero, e elege três obras ambientadas no Vale do Paraíba na década de 1850 como base para sua pesquisa. O já citado $O$ tronco do ipê, A escrava Isaura, de Bernardo Guimarães, cuja fazenda se situa "nos primeiros anos do reinado do Sr. D. Pedro II. [...], à margem do Paraíba", e Rei Negro (1914) de Coelho Neto, que se desenrola na fazenda "Cachoeira, uma das fazendas mais ricas do vale do Paraíba" 65.

São muitos os pontos que podemos identificar para estabelecer o diálogo do romance de Cornélio Penna com esta linhagem do romance de Alencar. Como aquele, os romances registram, durante a época áurea do café, um ambiente dominado pela figura do patriarca rural com sua família, agregados, escravos e visitantes, e são permeados por uma

\footnotetext{
${ }^{62}$ Sabemos que a primeira fase da grande expansão da cultura cafeeira se dá no início do século XIX, com a instalação da Corte portuguesa no Rio de Janeiro, quando ela se alastra pelo litoral da Capitania, sobe pelas encostas da Serra do Mar atingindo o Vale do Paraíba, de onde se estende em direção a Minas. Na Província de São Paulo, embora as primeiras experiências no plantio do café já se fizessem desde 1817 nos arredores de Campinas, foi só a partir de 1850 que as lavouras substituíram os engenhos de açúcar nesta região, que passa a ser um novo polo de irradiação desta cultura que vai se dirigindo para o Oeste da Província. Cf. CANABRAVA, Alice P. "A grande lavoura". In: História Geral da Civilização Brasileira. tomo II O Brasil monárquico. Vol. 6 Declínio e queda do Império...

${ }^{63} \mathrm{Cf}$. já observado por MACHADO, Regina M. A. Fiction et café dans une vallée impériale. Trois romans de la fazenda esclavagiste au Brésil. Paris : Indigo, 2011, p.27.

${ }^{64}$ BARBOSA, Paula Maciel. O idílio degradado: um estudo do romance Til de José de Alencar, 2012. Tese (Doutorado em Literatura Brasileira), FFLCH, Universidade de São Paulo, São Paulo, 2012. pp.194 - 202.

${ }^{65}$ MACHADO, Regina M. A. Fiction et café dans une vallée impériale - Trois romans de la fazenda esclavagiste au Brésil. Paris: Indigo, 2011.
} 
dimensão fantasmática e por um clima de mistério e desconfiança que, no entanto, sempre se esclarece nos romances de Alencar. A reconstituição do ambiente da casa-grande com todo o seu requinte e conforto (sobretudo em $O$ tronco do ipê em que esta é mais focalizada), os costumes, as superstições, as discrepâncias em relação aos que vivem em torno desses grandes proprietários e os escravos, assim como estes últimos como fonte de memória, são alguns dos traços presentes nos três romances. Até mesmo o isolamento junto à natureza, como vestígio do tempo da criação, e assim como modo de aproximação com o criador, está presente nos romances, sobretudo em $\mathrm{O}$ tronco do ipê e em $A$ menina morta, se lembrarmos que Da Mariana também busca refúgio na clareira da mata: "Mário, desviando-se do caminho que seguira, penetrava na mata. Ele conservara de sua infância esse amor da floresta, que se parece com o amor do oceano. A alma do homem carece para expandir-se, do elemento de que se criou: salsugem do mar, ou aroma agreste" 66 . No entanto, e apesar das aproximações com o romance de Alencar, em A menina morta não há a idealização ou a atenuação de conflitos próprias dos românticos, e a opressão e a angústia se dissemina por todos os personagens, dominando-os.

Já com O Guarani, romance de 1857 construído sob perspectiva diversa, e ambientado na mesma região do Vale do Paraíba, $A$ menina morta apresenta afinidades tanto no fato de situar a ação no passado, e desta forma revelar a construção e consolidação do Brasil como nação, como no modo com que o autor se refere à natureza, associada à cultura.

Mas enquanto Alencar confere um tom mítico à história de formação do Brasil, em que há um ocultamento da violência e até mesmo sua justificação, tendo em vista que o índio, livre, teria se submetido por sua própria vontade ao branco, Cornélio Penna desvela a violência do processo de consolidação do país, norteado pelos interesses dos proprietários.

Ao descrever o cenário em que se passa a ação de $\mathrm{O}$ Guarani, o narrador vincula Natureza e Cultura, harmonizando os dois polos.

A vegetação nessas paragens ostentava outrora todo o seu luxo e vigor; florestas virgens se estendiam ao longo das margens do rio, que corria no meio das arcarias de verdura e dos capitéis formados pelos leques das palmeiras.

${ }^{66}$ ALENCAR, José de. O tronco do ipê. 12a ed. São Paulo: Melhoramentos, 1965, p. 243. 
Tudo era grande e pomposo cenário que a natureza, sublime artista, tinha decorado para os dramas majestosos dos elementos, em que o homem é apenas um simples comparsa. ${ }^{67}$

... o crepúsculo reinava nas profundas e sombrias abóbadas de verdura: a luz, coando entre a espessa folhagem, se descompunha inteiramente; nem uma réstia de sol penetrava nesse templo da criação, ao qual serviam de colunas os troncos seculares dos acaris e araribás.(...) Álvaro de Sá, (...) saindo de sua meditação, viu-se de repente no meio do claro-escuro da floresta. ${ }^{68}$

A floresta, onde se mistura o luxo, como traço cultural, e o vigor da natureza, é vista como templo natural e é descrita com termos próprios da arquitetura, da mesma forma que vemos em A menina morta. Esta, como sublime artista, decora o cenário do drama que vai ter lugar ali, e é metaforizada, no romance de Alencar, com elementos próprios ao teatro.

Alencar chega mesmo a historicizar a natureza em $O$ Guarani, pois ao hierarquizar seus elementos parece sugerir uma transposição da servidão medieval e a sujeição incondicional do colonizado, naturalizando-a e, assim, justificando-a. ${ }^{69}$

Dir-se-ia que, vassalo e tributário desse rei das águas, o pequeno rio, altivo e sobranceiro contra os rochedos, curva-se humildemente aos pés do suserano. Perde então a beleza selvática; suas ondas são calmas e serenas como as de um lago, e não se revoltam contra os barcos e as canoas que resvalam sobre elas: escravo submisso, sofre o látego do senhor.

Embora não haja a mesma harmonia em $A$ menina morta ali se observa também, nas referências à natureza, a aproximação entre Natureza e Cultura:

As árvores estavam tão pesadas de folhagens e de parasitas que se curvavam sobre a estrada, debruçando-se de tal forma que havia ali espesso caramanchão, interminável túnel verde opulentado de flores coloridas, e em todo ele reinava a meia luz roxa entremeada de amarelo do sol coado pelos galhos, emaranhados em gestos de braços amigos. (...) Os claros-escuros da abóbada assim formada, em claustro sem fim, apoiado nas colunas das árvores em dórico severo, davam qualquer coisa de irreal a tudo, naquela manhã muito clara, e o mundo esfumava-se em tons de arte $e$ de artifício, que só a natureza sabe dar, quando imita a si mesma, para disfarçar a sua verdade demasiado rica e forte.

Os troncos das árvores servem de pilares à abóbada formada pelos galhos, como colunas em dórico severo. O dórico, que se caracteriza por sua austeridade, é ainda severo, e forma não mera passagem para a entrada da casa, mas um claustro sem fim, o que nos remete

\footnotetext{
${ }^{67}$ Idem. O Guarani. 2a.ed. São Paulo: Ateliê, 2000. p. 51/52

68 idem, Ibidem, p. 66.

${ }^{69} \mathrm{Cf}$. BOSI, Alfredo. "Um mito sacrificial: o indianismo de Alencar". In: Dialética da colonização.4a.ed. 5a.reimpr.São Paulo: Companhia das Letras, 2006, p.187. O crítico aponta como, seguindo o esquema feudalizante de interpretação da história proposto por Alencar, não só a sujeição do índio ao branco, mas a própria natureza que cerca o solar dos Mariz estaria a serviço dos conquistadores.
} 
imediatamente à arquitetura de conventos e mosteiros, e sugere a casa como clausura, isolamento, espaço em que a vida é pautada por um código rígido de comportamento. Tudo isso, iluminado pelos claros-escuros que perpassam pelas árvores que ressaltam, ao mesmo tempo, seu aspecto pictórico e provocam uma sensação de falta de realidade.

Embora a descrição do cenário também aproxime natureza e arte, e contenha os mesmos elementos que em Alencar, o que sugere o diálogo entre as obras, esta aproximação se coloca de forma diversa da anterior, pois opõe o comportamento humano ao da natureza, como se este contrariasse as leis naturais, conforme será explicitado adiante.

Ao afirmar que "o mundo esfumava-se em tons de arte e artifício que só mesmo a natureza sabe dar, quando imita a si mesma, para disfarçar a sua verdade demasiado rica e forte...", introduz conceitos como imitação e disfarce, e chama atenção para o caráter de representação da obra fazendo uma alusão à própria arte. ${ }^{70}$

Mas essa natureza construída, que remete à criação artística, pode também ser vista como construção emblemática da ordem que ali prevalece, sobretudo quando mais próxima da casa-grande. Ao introduzir a imagem do proprietário do Grotão, inicia com uma descrição da paisagem que alude à sua posição, pois como as árvores, pesam sobre ele as folhagens e parasitas. No entanto, embora se curvem igualmente à sua passagem, os galhos emaranhados não se oferecem como braços amigos.

... já entre as árvores, agora tornadas mais espaçadas, abria-se a espessa cortina aqui e ali, e deixavam ver as copas de altas palmeiras, sacudidas pelos ventos da manhã, com suas palmas estendidas em longos estandartes verdes, murmurantes, em sinal da proximidade da casa senhorial, pois eram elas que guarneciam a fachada da fazenda do Grotão, em duas ordens, e lançavam para a altura dos céus, sem esforço, seus fustes robustos e esguios" ${ }^{71}$

As palmeiras, muito comuns durante o Império, e que se vinculam à imagem do poder monárquico ${ }^{72}$, à ideia de nobreza, distinção e classe, lançam seus fustes robustos aos céus

\footnotetext{
${ }^{70}$ Conforme observado pelo Prof. Vagner Camilo

71 PENNA, Cornélio. Ibidem. p.747

72 Cf. D’ELBOUX, Roseli Maria Martins. “Uma promenade nos trópicos: os barões do café sob as palmeiras imperiais, entre o Rio de Janeiro e São Paulo". In: Anais do Museu Paulista.v.14.n.2.jul-dez. 2006. p.202. Disponível em: https://www.revistas.usp.br/anaismp/article/view/5450/6980. Acesso em 02/11/2017.
} 
em duas ordens: a do poder patriarcal e outra que o narrador não nomeia, e que pode ser pensada como de natureza espiritual.

Como não há distanciamento no olhar desse autor que, para tratar da matéria histórica não só volta sua narrativa para quase um século antes, como também nos remete àquele momento e àquele espaço, não como memória, mas como se falasse dali, talvez possamos supor que haja ainda um diálogo com o romance histórico.

Nas palavras de Fredric Jameson, ${ }^{73}$

O romance histórico não deve mostrar nem existências individuais nem acontecimentos históricos, mas a interseção de ambos: o evento precisa trespassar e transfixar de um só golpe o tempo existencial dos indivíduos e seus destinos. (...) 0 romance histórico, portanto, não será a descrição dos costumes e valores de um povo em um determinado momento de sua história; não será a representação de eventos históricos grandiosos (como quer a visão popular); tampouco será a história das vidas de indivíduos comuns em situações de crises extremas; e seguramente não será a história privada das grandes figuras históricas. Ele pode incluir todos esses aspectos, mas tão-somente sob a condição de que eles tenham sido organizados em uma oposição entre um plano público ou histórico (definido seja por costumes, eventos, crises ou líderes) e um plano existencial ou individual representado por aquela categoria narrativa que chamamos de personagens. Seu centro de gravidade, no entanto, não será constituído por tais personagens, ou por sua psicologia, suas vivências, suas observações, suas alegrias ou sofrimentos. Esse plano existencial pode incluir todos ou qualquer um desses aspectos, e o modo de ver do personagem pode variar do convencional ao disperso e pós-estrutural, do individualismo burguês ao descentramento esquizofrênico, do antropomórfico ao mais puramente actancial. A arte do romance histórico não consiste na vívida representação de nenhum desses aspectos em um ou outro plano, mas antes na habilidade e engenhosidade com que a sua interseção é configurada e exprimida...

Se o romance histórico se caracteriza pela presença de um evento histórico paradigmático que faz a mediação entre o plano existencial da vida individual dos personagens e o tempo histórico, me parece possível pensar que $A$ menina morta dialoga com essa forma narrativa. Afinal, a obra é construída como articulação entre o drama da escravidão, centro de nossa formação social cuja herança ainda está presente em nossas formas de sociabilidade, e aquele vivido pelos personagens, tendo em vista que essa relação social pressupõe, para além das relações de dependência, a não autonomia do sujeito em todos os níveis sociais: dos próprios escravos e dos homens brancos, pobres e livres. Indica também como ela distorce o comportamento dos proprietários, cuja prepotência e altivez desconhece os limites entre o eu e o outro.

${ }^{73}$ JAMESON, Fredric. "O romance histórico ainda é possível?". Trad. Hugo Mader. In: Revista Novos Estudos n77 - mar. 2007. pp.185-203. 
No entanto, e diferentemente do que propõe Jameson, o centro de gravidade da narrativa constitui-se pelas vivências dos personagens, suas reflexões e seu sofrimento. As personagens, dominadas pelo sentimento de uma emancipação impossível, parecem presas a um movimento circular, com esperanças que se fazem e se desfazem, num mundo condenado a se repetir.

Para Alfredo Bosi, Cornélio Penna se insere na linha do romance intimista ou introspectivo, afetado pelas angústias religiosas de seus autores. Esta tendência da ficção seria marcada por um "retorno das consciências religiosas às suas fontes pré e antiburguesas 174 , que através de um realismo subjetivo, criariam personagens norteados pelo conflito entre o mundo e a graça divina.

Subindo ao primeiro plano os conteúdos da consciência nos seus vários momentos de memória, fantasia ou reflexão, esbatem-se os contornos do ambiente, que passa a atmosfera; e desloca-se o eixo da trama do tempo "objetivo" ou cronológico para a duração psíquica do sujeito.

Com efeito, embora definidos os contornos do ambiente, e configurado um tempo "objetivo", os conflitos em Cornélio Penna são subjetivados e o enfrentamento com o mundo não se dá pela ação. A apreensão da realidade é atravessada por uma perspectiva subjetivista, e os conflitos interiores se evidenciam no contato com o outro. Os personagens se veem envolvidos em um ambiente de hostilidade e de mistério, mas não se confrontam, optando pelo isolamento e incomunicabilidade.

Os objetos, muitas vezes antropomorfizados, também são envolvidos nesta áurea soturna. Junto aos personagens, que por sua vez são coisificados, parecem compor o ambiente de angústia em que vivem. É ilustrativa, como exemplo, a descrição do lampião de querosene que, como a casa, evoca a memória daqueles que, mesmo ausentes, se perpetuam ali, e cuja presença ressoa na interioridade dos moradores da fazenda:

... vulto alto e imóvel cujos olhos sem brilho fixavam um ponto vago, indeciso, apesar de sua impressionante fixidez. Eles deviam ver alguma coisa que ninguém mais via e que desaparecera para sempre, mas cuja memória ficara marcada em todos os detalhes daquela sala enorme, esculpidos em cada móvel e nela vivendo como perfume distante e persistente. ${ }^{75}$

\footnotetext{
${ }^{74}$ BOSI, Alfredo. História concisa da Literatura Brasileira. São Paulo: Cultrix, 1994. p.390.

${ }^{75}$ PENNA, Cornélio. Ibidem. p.784
} 
O clima de mistério reforçado pelos relatos interrompidos, pelos enigmas e nãoditos, nos sugerem inicialmente uma leitura que se assemelharia à dos romances policiais, uma vez que buscamos seguir pistas para esclarecer o que o texto não diz. No entanto, nos damos conta que longe de formar um determinado sentido a partir das questões disseminadas no texto, não temos como buscar respostas. A atmosfera de angústia que o romance transmite figura um mundo que aprisiona e que contém mistérios que não têm como ser desvendados.

O autor dialoga, portanto, com diferentes formas romanescas, recusando-se à filiação a alguma delas. Todo o texto é permeado por ambiguidades, que vão dos acontecimentos do mundo narrado à própria caracterização do romance. 


\section{Particularidades no tratamento da matéria histórica}

Embora a perspectiva da narrativa seja a da intimidade e do cotidiano de uma família patriarcal no Vale do Paraíba no século XIX, ela se articula com a estrutura social e política do Segundo Reinado. O romancista trabalha com questões históricas pontuais, citadas como que de passagem, assim como com indicações geográficas, o que nos permite situar a narrativa tanto no tempo quanto no espaço.

Chama a atenção, entretanto, o tratamento dado pelo autor à matéria histórica, que constitui uma das particularidades do romance. De um lado, as referências aparecem diluídas e são apresentadas como algo episódico; de outro, são precisas e cuidadosamente inseridas na narrativa.

Algumas passagens ilustram bem esse procedimento de oscilação entre a indefinição e a precisão dos elementos históricos, de modo análogo ao aparente paradoxo, apontado anteriormente, entre o excesso de pormenores e os não ditos do texto.

A construção de estradas e ferrovias que ligavam o Vale do Paraíba ao Rio de Janeiro constituem uma das principais indicações do período em que transcorre a narrativa ${ }^{76}$. A partir da declaração do Comendador de receber a filha que chega da Corte "no ponto terminal da Estrada de Ferro D.Pedro II, em Entre Rios", inferimos que a ação se passa entre 1867 e 1871, uma vez que a estação de Entre Rios, hoje Três Rios, foi inaugurada em 13 de outubro de 1867 e foi estação final da linha até 1871, quando inaugurada a estação de Porto Novo, hoje Além Paraíba, na divisa da Província de Minas Gerais com a do Rio de Janeiro77, mais próxima da fazenda do Grotão.

\footnotetext{
76 Esse aspecto, já foi apontado por Costa Lima em $\mathbf{O}$ Romance em Cornélio Penna. 2a edição revista e modificada. Belo Horizonte: Editora UFMG, 2005, p.102. No entanto, ali as referências das duas ferrovias parecem misturadas, conforme a explicação que se segue, e em acordo com a confusão que o texto parece intencionalmente criar.

77 Os trabalhos de construção da Estrada de Ferro D. Pedro II, hoje Central do Brasil, tiveram início em 1855 e visavam à ligação da Corte com as capitais das Províncias de Minas Gerais e São Paulo. A linha, que partia da Capital, transpunha a Serra do Mar, de onde se bifurcava em dois ramais: um que ia até a província de São Paulo, em Cachoeira (atual Cachoeira Paulista, então ponto final da navegação pelo Alto Paraíba), e o outro ao Porto Novo do Cunha, nos limites das províncias do Rio de Janeiro e Minas Gerais. Em 1864 a linha alcança Barra do Piraí e em 1867 Entre-Rios, chegando a Porto Novo do Cunha em 1871. Enquanto o ramal de São Paulo chega a Cachoeira em 1875, o de Minas segue por Juiz de Fora (1875), Barbacena (1880) até chegar a
} 
Em outra passagem, o patriarca faz referências à demora na execução do trecho de ferrovia entre a Serra da Estrela e Petrópolis, em função do quê manda vir animais de uma sesmaria de seu pai em Pindamonhangaba, para poder escoar a safra até os portos ${ }^{78}$.

Esperava na realidade a estrada de ferro, mas esta continua a ser um pequeno sonho... que decerto se tornará grande. Porém quando vi no mapa do Império o traçado de nosso único caminho de ferro parado diante da Serra da Estrela, tão pequenino, compreendi que as palavras, os discursos e os artigos que tenho lido eram apenas de entusiasmo eleitoral. Mandei vir agora bestas de São Paulo, da fazenda de meu pai, na sesmaria de Pindamonhangaba... ${ }^{79}$

O personagem fala em único caminho de ferro, embora não fosse o único, em função de se tratar aqui da Estrada de Ferro Mauá ${ }^{80}$ e haver também, nesse período, a Estrada de Ferro D. Pedro II. Além disso, é em 1856 que a ferrovia Mauá chega à raiz da serra, sendo inaugurado o trecho até Petrópolis só em 1883, enquanto a E.F.D.Pedro II atinge Barra do Piraí, no vale do Paraíba em 1864 e Entre-Rios em 1867.

Dạ Virgínia, em outro trecho, também se refere ao caminho de ferro da raiz da serra, mas desta vez nomeando a ferrovia:

... vieram-lhe à mente os perigos que iria correr, levada através dos montes e das matas em sua liteira, tão sozinha, acompanhada apenas por um velho inteiramente indiferente, e sobretudo quando tivesse de embarcar no caminho de ferro lá na raiz da serra (...). Há tantos anos estivera na Corte que não se lembrava mais... Agora, pelas cartas do primo José e também pelos jornais do primo Comendador lidos com insatisfeita curiosidade todos os dias, compreendia ter mudado muita coisa e já não

Ouro Preto (1888). Cf. Odilon Nogueira de Matos. "Vias de comunicação". In: História Geral da Civilização Brasileira, Tomo II - O Brasil Monárquico. Vol. 6 Declínio e queda do Império, p. 58 a 67.

78 Sabemos que os tropeiros levavam as mercadorias até os portos de Paraty e Angra dos Reis, de onde eram embarcadas para a Capital. Ao se referir à propriedade do pai como uma sesmaria, o Comendador reafirma a política de concessões suspensa em 1822, que havia transformado antigos sesmeiros em grandes proprietários.

79 PENNA, Cornélio. A Menina Morta. In: Cornélio Penna Romances Completos. Rio de Janeiro, José Aguilar, 1958, pp. 899-900.

${ }^{80}$ A Estrada de Ferro Mauá, devia ligar o Rio de Janeiro ao Vale do Paraíba e, mais tarde, a Minas, por um trajeto misto: por mar, do Rio até o porto Mauá, na Baía da Guanabara; por estrada de ferro, de Mauá até a Serra da Estrela; por estrada de rodagem, daí até Petrópolis - em função das dificuldades técnicas para que se transpusesse a serra naquela direção - e novamente por estrada de ferro de Petrópolis em diante. Em 1854 é inaugurado o primeiro trecho da ferrovia que, dois anos depois, chega à raiz da serra de Petrópolis e contava com a estrada até Petrópolis e com a Rodovia União e Indústria para o transporte de mercadorias do interior. Cf. MATOS, Odilon Nogueira de. "Vias de comunicação". In: HOLANDA, Sérgio Buarque de. (Dir.). O Brasil monárquico. Declínio e queda do Império. Tomo II vol. 6. História geral da civilização brasileira. Rio de Janeiro: Bertrand do Brasil, 2004, p. 64-65.

O trecho até Petrópolis, no entanto, só será inaugurado quase 30 anos mais tarde, em 1883 pela E. F. Príncipe do Grão Pará, que acabou por comprar a E. F. Mauá em 1888. 
era tão longe a grande cidade, pois o caminho pela Estrada de Ferro Mauá e pelas barcas encurtara as distâncias ${ }^{81}$.

Como leitor não nos damos conta de imediato que se trata de dois caminhos distintos, ou que a Estrada de Ferro Mauá não é caminho complementar ao da Estrada de Ferro D. Pedro II, como parece figurar na narrativa à primeira vista. Tendo em vista estarmos falando de um romance, esta poderia ser entendida como simples imprecisão, própria da construção de uma narrativa ficcional.

No entanto, ao atentarmos para o texto, podemos observar que em passagem posterior, uma das parentas comenta que não sabe como Da. Virgínia, que tem uma ação da Estrada de Ferro Mauá, não fez com que viajassem por ela, mostrando que a distinção entre os dois caminhos está colocada e indicando que, ao mesmo tempo em que o autor cria a ambiguidade, constrói uma narrativa fiel à matéria narrada.

A mesma questão surge com relação à Companhia do Mucuri, o que aumenta a suspeita de que há no texto um embaçamento das indicações históricas e portanto temporais, quando Manuel Procópio comenta ter lido no Jornal do Comércio sobre as condições vantajosas obtidas pela Companhia, que "conseguiu obter do governo maiores privilégios além dos de navegação do rio, do porto de S. José até os da Bahia e do Rio de Janeiro, o de marcar fretes sem limitação, o de cobrar os impostos de todas as obras dentro de cinquenta anos, além do mais..." , mas não conclui porque é interrompido pelo Comendador.

É curioso observar que os privilégios a que o agregado faz referência são extremamente precisos e em acordo com o que ficou estabelecido entre o governo imperial e a Companhia de Navegação e Comércio do Mucuri, fundada pelos irmãos Teófilo e Honório Ottoni.

O empreendimento tinha como objetivo principal estabelecer uma ligação da região centro-oeste da província de Minas Gerais ao litoral, o que seria viabilizado por meio da navegação do rio Mucuri. Mais precisamente, ligar as comarcas de Serro Frio (atual município de Serro) e Jequitinhonha no Nordeste de Minas com o litoral sul da província da

\footnotetext{
${ }^{81}$ PENNA, Cornélio. A Menina Morta. In: Cornélio Penna Romances Completos. Rio de Janeiro, José Aguilar,
} 1958, p. 873. 
Bahia pelo rio Mucuri e, a partir daí, pela costa até o Rio de Janeiro. Seria criada assim uma nova rota comercial entre o Norte de Minas Gerais e a capital do Império. Pelo acordo, caberia à empresa também abrir estradas e povoar a região, distribuindo terras ao longo da malha viária e fluvial que se propunha a construir, de forma a satisfazer, ao mesmo tempo, os objetivos de exploração econômica da rede de transportes e a política do Império de colonização e de interligação entre as regiões.

Constituída como sociedade por ações em 1847, a Companhia só inicia seus trabalhos em 1851. São muitos os incentivos que recebe, tanto do governo imperial como da província de Minas Gerais, e daí os privilégios a que se refere o Sr. Manuel Procópio. Pelo contrato com o governo geral os empresários contariam com:

- O direito exclusivo de navegação a vapor entre o porto de S. José de PortoAlegre (atual Mucuri) no litoral sul da Bahia com o Rio de Janeiro, por um período de quarenta anos.

- O direito exclusivo de navegação a vapor, ou qualquer outro meio, por todo o rio Mucuri e seus confluentes, até o ponto em que, oito anos depois de começado o prazo do privilégio, a companhia tivesse conseguido fazer chegar periodicamente os seus barcos. Só seriam permitidas embarcações a vela nos trechos em que estas já operavam anteriormente, canoas de pescaria, e as de um só madeiro quando conduzissem gêneros da lavoura de seus donos.

- O direito de marcar os fretes, ou seja, fixar o preço dos fretes praticamente sem restrições.

- A isenção de quaisquer impostos sobre os produtos, exportados ou importados, transportados pelo Rio Mucuri em barcos da companhia, ou pelas estradas que ela construísse enquanto durassem os seus privilégios, de forma exclusiva.

- O direito no fim de quarenta anos de receber do governo indenização pelas obras que tivessem construído, tais como armazéns, canais, comportas, diques e cais, no estado em que se achassem. Caso não houvesse interesse por parte do Governo, o contrato ficaria prorrogado por mais quarenta anos, 
findo os quais deveriam ser cedidas gratuitamente todas as mencionadas obras. $^{82}$

Sem dar muita atenção ao velho agregado, o Comendador critica o projeto como coisa de "luzias", aludindo ao seu autor, cuja atuação política esteve sempre ligada ao Partido Liberal ${ }^{83}$, e reafirma sua posição conservadora, partidário dos "saquaremas". Ao mesmo tempo, declara-se contrário à intervenção do Estado na política de imigração, já que como contrapartida dos benefícios recebidos do Governo a empresa se comprometia a introduzir no vale do Mucuri pelo menos 3.000 colonos até o fim de 1859.

-É mesmo coisa de 'luzia', e eu sempre fui pelos 'saquaremas' - disse o Comendador com desdém. Em tudo isso há muita coisa romanceada, como a história das cem léguas de linha de navegação que afinal eram só trinta e a companhia passou a ser de estrada em vez de ser de navegação... é preciso muita boa vontade e imaginativa para se acreditar nesses planos fantásticos. Para mim, a colonização do interior do Brasil terá que ser feita individualmente. Cada homem deve abrir a sua fazenda e depois reunir-se em grupos de onde surgirão as cidades. Está aí Porto Novo como prova do que digo. O resto é coisa de gabinete, feito sobre tapetes de pelúcia, com penas de pato bem aparadas!... ${ }^{84}$

Como a navegabilidade do rio se mostrava precária, tornou-se necessária a construção de estradas paralelas a alguns desses trechos. Assim foi construída a primeira estrada de rodagem do interior do Brasil ${ }^{85}$ : a Estrada de Santa Clara inaugurada em 1857, que ligava as imediações da cachoeira de Santa Clara (atual Nanuque) no litoral, à freguesia que se formou então na região, e à que se deu o nome de Filadélfia (atual cidade de Teófilo Ottoni).

\footnotetext{
82 Estabeleciam ainda os respectivos contratos que:
}

. O governo cederia à companhia, para a fundação de colônias agrícolas e industriais, dez léguas de terras de testada com uma de fundo das terras devolutas à margem do rio Mucuri em território da província de Minas para que as cultivasse e povoasse no período de até dez anos;

. A empresa teria ainda o direito exclusivo na abertura das estradas das comarcas ao norte das margens do Mucuri, o que resultava no monopólio de todas as comunicações das comarcas do norte de Minas pelo espaço de oitenta anos, assim como a garantia, sem ônus de sua parte, de um destacamento de 30 praças ao longo do rio em local que a Companhia achasse conveniente.

83 Teófilo Ottoni foi, além de deputado provincial na Assembleia de Minas, deputado na Assembleia Geral no Rio de Janeiro e senador, um dos líderes da Revolução Liberal de 1842 em Minas.

84 PENNA, Cornélio. A Menina Morta. In: Cornélio Penna Romances Completos. Rio de Janeiro, José Aguilar, 1958, p.818.

85 MATOS, Odilon Nogueira de. "Vias de comunicação". In: HOLANDA, Sérgio Buarque de. (Dir.). O Brasil monárquico. Declínio e queda do Império. Tomo II vol. 6. História geral da civilização brasileira. Rio de Janeiro: Bertrand do Brasil, 2004, p.58. 
Com pouco mais de 180 quilômetros de extensão, e responsável pela ocupação da região, a obra parece justificar o comentário do fazendeiro de que a Companhia do Mucuri se transformara de companhia de navegação em companhia de construção de estrada, e de que de 100 léguas de navegação foram apenas trinta, uma vez que após assinatura da criação da Cia do Mucuri constatou-se que o trecho navegável do rio Mucuri era menor do que o anteriormente previsto.

A companhia acaba sendo encampada pelo Governo em 1860 e posteriormente é decretada a sua falência. O período, portanto, de sua história é anterior ao do tempo narrado. Embora possamos supor que a menção à Companhia pode estar relacionada à morte de Teófilo Ottoni em 1869, ou a qualquer outro acontecimento relativo ao empreendimento, me parece curiosa a referência, em função de seu deslocamento temporal. Mais que isso, chama a atenção o nível de detalhamento do comentário, sobretudo se considerarmos que não se trata de um acontecimento nuclear na história, e que há o intervalo de quase um século entre o tempo da narrativa e o tempo da narração.

O diálogo reproduzido abaixo também parece reforçar o procedimento utilizado pelo autor, conforme referido anteriormente. Trata-se de uma conversa entre o Comendador e um visitante que comenta o arrefecimento das repercussões da crise.

- Parece-me terem sido cinco anos bastantes para se ter esgotado o assunto que, aliás, não nos interessou muito de perto. Já vimos que os norte-americanos, seus autores manifestos, pagam agora bem caro a sua imprudência - disse com sorriso afável o fazendeiro.

- Mas, meu senhor, a repercussão no Brasil foi muito grande, e ainda perdura - murmurou, com timidez, o outro convidado...

- O Brasil é muito vasto - respondeu-lhe, ainda a sorrir, o Comendador e pousou o garfo, ... e o nosso império é um colosso formado de pequenos pedaços mal ligados que deixam inúmeras fendas entre eles. Qualquer gota d'água, qualquer sopro, se infiltra nessas fissuras e dificilmente depois se evaporam... Assim é que o ouro da Califórnia com sua aparição súbita veio até nós perturbar os nossos mercados, e a alta de certos artigos, como a baixa de outros, nos trouxe um desequilibrio que ainda nos prejudica.

... Entretanto, - continuava, agora, serenamente, o fazendeiro - tenho esperança de que a minha colheita se escoe perfeitamente para o exterior pois a procura começa a ser grande, e o mercado de Hamburgo entrou em plena atividade completamente restabelecido.

As referências são alusivas a uma crise em que os Estados Unidos figuram como seus autores manifestos. Embora o personagem não a nomeie, os comentários permitem entrever que se trata da crise provocada pela Guerra Civil Americana que promoveu a 
libertação dos escravos em 1865, e cujos reveses na economia dos estados confederados do Sul, em função da diminuição da produção de algodão e de açúcar, serviam de argumento contra as iniciativas para a libertação dos escravos. Apesar da recuperação da produção algodoeira que foi gradativamente aumentando, mas que até então se mantinha abaixo dos níveis anteriores à guerra ${ }^{86}$, a da indústria açucareira foi ainda mais difícil, pois além da queda da produção houve um significativo aumento no consumo interno, tornando o país inteiramente dependente das importações.

O discurso do deputado saquarema João de Almeida Pereira Filho, pronunciado em 02 de agosto de 1871 durante as discussões para aprovação da Lei do Ventre-Livre, parece ilustrar a questão:

Todos os espaços tropicais americanos que se viram forçados a abdicar do braço escravo regrediram economicamente, inclusive o Sul: Os Estados Unidos que exportaram um ano antes da Guerra cerca de cinco milhões de balas [i.é, bales RBM] de algodão, ainda hoje, apesar de terem concentrado a atenção especialmente sobre esta cultura, que consideram mais fácil e vantajosa, a produção não chegou a três milhões de balas, notando-se que isto é agora, já muitos anos depois da Guerra. (...) Se lá nos Estados Unidos onde há canais, extensas redes de caminhos de ferro, onde há uma navegação cuidada, uma indústria fabril rival da Europa, onde há instrução profissional, acontece isso; o que deve acontecer a este infeliz país? ${ }^{87}$

Embora minimizadas pelo Comendador as repercussões no Brasil do que se passava nos Estados Unidos, em acordo com a defesa dos seus interesses escravocratas, elas são reafirmadas pelo seu interlocutor, que alega que mesmo passados cinco anos, elas ainda reverberavam por aqui. Se pensarmos no que se deu historicamente, a libertação dos escravos no maior país escravista da América acendeu o debate político e as deliberações parlamentares sobre a escravidão no Brasil que culminaram com a Lei do Ventre-Livre, citada também posteriormente.

Mas é curioso que ao mesmo tempo que o autor fala de uma questão da época, ele cita a descoberta do ouro na Califórnia, ocorrida em 1848, portanto 20 anos antes, e do

\footnotetext{
${ }^{86}$ Os estados do Sul dos Estados Unidos só atingem os níveis de produção de algodão anteriores à guerra em 1879 , período portanto posterior ao tempo da narrativa, quando inclusive os ultrapassam.

${ }^{87}$ Cf. MARQUESE, Rafael de Bivar. "A Guerra Civil dos Estados Unidos e a crise da escravidão no Brasil" ， em que analisa as articulações entre o fim da escravidão nos Estados Unidos e a crise da escravidão brasileira, sobretudo no período entre 1861-1871, p.19 Originalmente apresentado na Conferência Internacional American Civil Wars: The Crisis of the 1860s in the US, Latin America, and Europe, realizada na Universidade da Carolina do Sul, março de 2014.
}

Disponível em: http://www.usp.br/iri/documentos/paper_rafael_marquese.pdf Acesso em: 09/10/2017. 
restabelecimento do mercado de Hamburgo, que não sabemos se diz respeito à crise que havia afetado o mercado europeu, ou ao porto de Hamburgo, um dos principais portos pelos quais os produtos brasileiros entravam na Europa, atingido pelo grande incêndio que destruiu um quarto da cidade em 1842. E imediatamente redireciona o diálogo para aquilo que está ligado aos seus interesses particulares: o escoamento da produção das suas propriedades. O autor localiza a discussão, embaça as referências e reafirma o papel social do proprietário que se preocupa basicamente com o que afeta seus negócios, indicando sua altivez ao tratar de um assunto que não Ihe interessa discutir. Sabemos que, cessado o tráfico negreiro em 1850, a impossibilidade de reprodução natural da escravaria com a lei que libertava as crianças filhas de mães escravas condenava o sistema escravista.

Quanto à descoberta de jazidas de ouro na Califórnia, esta havia exigido investimentos em infraestrutura em uma economia ainda incipiente, como era a economia americana de então ${ }^{88}$, implicando o aumento das importações. As importações drenaram em grande parte as reservas em ouro do país e acabaram por levar a uma crise que culminou inclusive na falência de diversas instituições financeiras a partir de 1857.

Assim, ao afirmar os americanos como autores da crise, e ao se referir aos efeitos da descoberta do ouro na Califórnia ${ }^{89}$, podemos pensar que o Comendador estaria se referindo à crise de $1857 / 1858$, de caráter internacional com forte impacto na desvalorização cambial da moeda brasileira, cujos reflexos não chegaram a atingir a economia cafeeira ${ }^{90}$, e embaralhando ainda uma vez as indicações temporais.

É importante notar ainda com relação à descoberta do ouro na Califórnia, que o porto do Rio passa a integrar o comércio externo norte-americano a partir de então. Os navios americanos que saíam da costa leste dos Estados Unidos faziam escala na Bahia e no Rio antes de se dirigirem à Califórnia, uma vez que não havia a passagem pelo Canal do

\footnotetext{
${ }^{88}$ A Europa, por sua vez, passava por um momento favorável da economia, tanto em função dos juros e dividendos recebidos dos empréstimos internacionais efetuados, como do reaquecimento da economia após o fim do conflito entre a Prússia e a Áustria. (ver José Tadeu de Almeida)

89 Cf. ALENCASTRO, Luiz Felipe de. "Modelos da História e da Historiografia Imperial". In: História da vida privada no Brasil: Império: a corte e a modernidade nacional, pp. 40-42.

90 A desvalorização da moeda era compensada pelo aumento dos preços do café, e cujos custos de produção não sofriam o impacto da desvalorização cambial. Sergio Buarque de Holanda. Fartura e crise. In: História Geral da Civilização Brasileira - Tomo II - O Brasil monárquico, vol.7 Do Império à República.
} 
Panamá, trazendo produtos manufaturados que penetram em grande número no mercado brasileiro. O caminho alternativo exigia o desembarque no Atlântico, a passagem por terra pelo istmo do Panamá e novo embarque no Pacífico.

No entanto, e apesar do deslocamento que a descoberta do ouro insinua, a questão da escravidão é retomada. Desta vez é um deputado provincial, de passagem pelo Grotão, que menciona que as leis que vinham sendo tratadas nos bastidores do poder, ocupavam a questão mais importante do momento, e que parecem dizer respeito às discussões que precederam a Lei do Ventre Livre ${ }^{91}$.

Cabe observar aqui que as questões colocadas são objeto de comentários feitos sempre pelos homens da casa, e nos chegam a partir de fragmentos de conversas entre eles, confirmando o lugar ocupado pelas mulheres, assim como nos igualando, enquanto leitores, a elas. Apartadas da vida pública, a elas cabia ouvir mais do que falar, e delas, assim como dos filhos ou escravos, só se esperavam comentários quando solicitados.

Presente durante todo o período que vai de 1866 a 1871, o debate sobre a chamada Lei dos Nascituros se acirra a partir de 1869 até sua aprovação durante o governo de Rio Branco em setembro de 1871.

Embora enquanto propriedade seja do âmbito da ordem privada, a escravidão não apenas se vincula à ordem pública para legitimar-se como instituição, como se constitui em questão nacional, encaminhada pelo Estado imperial como forma de concretizar sua função ordenadora e reguladora. Conforme aponta Luiz Felipe de Alencastro,

Como na Colônia, a vida privada brasileira confunde-se, no Império, com a vida familiar. Resta que, no decorrer do processo de organização política e jurídica nacional, a vida privada escravista desdobra-se numa ordem privada prenhe de contradições com a ordem pública. Manifesta-se a dualidade que atravessa todo o Império: o escravo é um tipo de propriedade particular cuja posse e gestão demandam, reiteradamente, $\mathrm{o}$ aval da autoridade pública. ${ }^{92}$

Com o fim da Guerra Civil Americana a questão da escravidão é então retomada por iniciativa do próprio Imperador que, na fala do Trono em 1866, ou seja, ao abrir os trabalhos

\footnotetext{
${ }^{91}$ Cf. PENNA, Cornélio. A Menina Morta. In: Cornélio Penna Romances Completos. Rio de Janeiro, José Aguilar, 1958, p.1182.

92 ALENCASTRO, Luiz Felipe de. "Vida privada e ordem privada no Império". In: (Org.) História da vida privada no Brasil II - Império: a corte e a modernidade nacional. São Paulo: Companhia das Letras, 1997, p. 16.
} 
parlamentares, declara que o problema da escravidão não tinha mais como ser contornado, relatando a preocupação de que o Império do Brasil viesse a isolar-se internacionalmente caso não encaminhasse alguma solução. Disposta a mostrar suas intenções reformadoras ${ }^{93}$, principalmente no exterior, a Coroa redige uma resposta à Junta Francesa de Emancipação, que havia conclamado o Imperador a tomar medidas a favor da abolição ${ }^{94}$. Nesta carta ele afirma que a questão da emancipação seria tratada com prioridade assim que terminasse a guerra do Paraguai, e que a emancipação no Brasil era apenas uma questão de forma e de oportunidade.

No início de 1867 são encaminhados os projetos de Pimenta Bueno, futuro Visconde de São Vicente, ao Conselho de Estado, referentes à conveniência da abolição gradativa da escravidão até sua abolição total prevista para o fim de 1899. Embora os conselheiros, na sua maioria, se dissessem favoráveis ao projeto ${ }^{95}$, adiaram o debate para quando terminasse a guerra. ${ }^{96}$ É designada, no entanto, uma comissão para organizar um projeto que contemplasse as ideias que tivessem tido a aprovação da maioria no Conselho, com exceção da que fixava o prazo final para a extinção da escravatura. Esse projeto, que manteve os pontos mais importantes daquele apresentado por Pimenta Bueno, foi o texto que serviu de base à lei de 28 de setembro de 1871.

O gabinete Zacarias, favorável ao projeto da futura Lei do Ventre Livre, é substituído em 1868 pelo do Visconde de Itaboraí, avesso a qualquer medida emancipacionista, convocado por sua capacidade de intervir nos assuntos do Prata.

\footnotetext{
93 Em novembro do mesmo ano, com o mesmo objetivo, o governo baixa um decreto concedendo liberdade para os escravos designados para o serviço militar.

94 Depois de abolida em 1865 nos Estados Unidos, só o Brasil e Cuba, dentre os países ocidentais, ainda admitiam a escravidão. Essa se mantinha ainda nas colônias portuguesas, mas uma lei de 1858 estabelecera que, em vinte anos, seriam considerados livres todos os escravos pertencentes a súditos portugueses. "Começam a aparecer, então, manifestações internacionais hostis a estes últimos países que conservavam um regime social universalmente condenado". Cf. PRADO JR., Caio, História econômica do Brasil. São Paulo, Brasiliense, 17ạed., 1974. Pág. 176.

95 Com exceção do marquês de Olinda e do barão de Muritiba, todos os conselheiros se mostraram, em princípio, favoráveis à libertação dos nascituros.

${ }^{96}$ Sergio Buarque de Holanda. Fim do Segundo Quinquênio Liberal e A marcha da idéia da emancipação. In: História Geral da Civilização Brasileira - Tomo II O Brasil Monárquico - vol. 7 e José Murilo de Carvalho. $A$ política de abolição: o rei contra os barões. In: Teatro de Sombras. p. 278 a 290.
} 
Mas depois de um período em que se paralisam todas as negociações de emancipação, o Imperador começa a articular em 1870 a substituição de Visconde de Itaboraí, depois de comunicar-Ihe a necessidade de um novo Gabinete que levasse adiante a questão da emancipação dos filhos de mulheres escravas. Em meio a uma grave crise entre o Ministério e D. Pedro, assim como entre os próprios conservadores, o então chefe de governo renuncia ${ }^{97}$.

É, portanto, longo o processo de discussão da lei que tornava livres os filhos de escravos nascidos a partir da sua promulgação. O personagem chega mesmo a mencionar a crise do então Ministério Conservador sob ameaça de queda, reafirmando a fidelidade da narrativa aos acontecimentos históricos, em um momento de grande instabilidade política ${ }^{98}$.

Há ainda várias outras referências históricas na narrativa, como comentários sobre os acontecimentos da guerra, que supomos serem relativos à Guerra do Paraguai (1864-1870) então em curso, (apenas mencionados como "os acontecimentos guerreiros relatados pelos jornais"), sobre a expansão dos cafezais para o Oeste paulista, e sobre os imigrantes portugueses cujo canto se ouve ao longe. Embora grande a resistência ao trabalho livre, alguns proprietários de terras, até mesmo na região fluminense, experimentavam empregar trabalhadores livres em suas fazendas. Além desses, havia também colonos, vindos na sua grande maioria de Portugal, trabalhando na Estrada de Ferro D. Pedro II em virtude de uma das cláusulas de seu contrato ${ }^{99}$. A febre amarela que acomete o fazendeiro e seu filho mais novo também pode ser considerada como um indício temporal, pois depois de uma ausência relativamente prolongada durante a década de 60 , ela reaparece em 1868 , mantendo-se até a campanha de erradicação de Oswaldo Cruz.

\footnotetext{
97 Depois de um curto período com Pimenta Bueno, jurista de renome, mas pouco afeito às negociações políticas à frente do Gabinete, José Maria da Silva Paranhos, Visconde do Rio Branco, é chamado para substituílo e formar um novo ministério.

98 De 1868 a 1878 são nomeados sucessivamente quatro presidentes conservadores para o Conselho dos Ministros: Visconde de Itaboraí (1868), Visconde de S. Vicente (1870), Visconde do Rio Branco (1871) e Duque de Caxias (1875).

${ }^{99}$ Emília Viotti da Costa. Primeiras experiências de trabalho livre. In: Da senzala à colônia. p. 109 a 167.
} 
O narrador chega a citar, inclusive, um personagem histórico, o então Bispo do Rio de Janeiro Dom Manuel do Monte Rodrigues de Araújo ${ }^{100}$, bispo de Irajá, que teria autorizado tanto as celebrações de missa no oratório da capela como concedido licença de cemitério nas terras do Grotão, reforçando o procedimento que utiliza e que oscila entre a indefinição e a precisão.

Mas em meio a uma precisão que se combina com certo embaçamento dos fatos, e que provocam o leitor, o aspecto que mais chama atenção no romance é a questão da sobrevivência da fazenda que contraria o que se deu historicamente nas propriedades que dependiam exclusivamente da mão-de-obra escrava. Mesmo depois de alforriados os escravos, não se vê a decadência da fazenda, mas a retomada de suas atividades, conforme explicitado no texto. $\mathrm{O}$ autor não fala como os trabalhos são retomados depois de libertos os cativos, nem se o são com mão de obra negra ou não.

Os dias, os meses e os anos se escoaram em seu ritmo sempre igual, na ampulheta do silêncio, da renúncia e da serena tristeza sem remédio.... As armadilhas sutis do nada, do ausente e do real perdiam-se na corrida implacável do tempo, e a casa, na desordem estática de seus quartos numerosos, das salas em grandes espaços, os terreiros calcinados pelo sol, as senzalas silenciosas e indecifráveis, a floresta invasora e tenaz, com seu horror sombrio, onde as serpentes adormeciam agora em paz, livre das línguas abrasadoras e dos turbilhões acres das queimadas, dos machados desumanos que despedaçavam suas árvores seculares ainda intumescidas de seiva poderosa, tudo caminhava em atropelo, na cegueira de sua marcha.

O trabalho, depois do torpor do primeiro desânimo, surgira, a princípio escondido e tímido, mas logo outra vez invencível voltou a fecundar os campos e as colinas com suas plantações opulentas, com seus arbustos quase negros pejados de frutos sumarentos e rubros, e os bois já não soltavam mais seus longos mugidos de medo primitivo, deixados sozinhos nos pastos desertados pelos campeiros. ${ }^{101}$

Sabemos que o declínio da mineração em fins do século XVIII forçou os colonizadores a procurarem novos meios de subsistência. É então que o café passa a ser cultivado na região do Vale do Paraíba onde, por volta de 1875, depois de quase um século de expansão, entra em declínio.

100 “Era dia santo. (...) A fazenda tinha licença de cemitério e de missa em seu oratório, por provisão do Bispo do Rio de Janeiro, Dom Manuel do Monte Rodrigues de Araujo, com a obrigação de explicar a doutrina cristã pelo catecismo, e logo depois do ofício divino, antes de entrar para a sacristia, fazer os atos de fé, esperança e caridade". PENNA, Cornélio. A Menina Morta. In: Cornélio Penna Romances Completos. Rio de Janeiro, José Aguilar, 1958, p.998.

101 PENNA, Cornélio. A Menina Morta. In: Cornélio Penna Romances Completos. Rio de Janeiro, José Aguilar, 1958, p.1295. 
As técnicas de cultivo e o desmatamento intensivo através de queimadas reduziam a fertilidade das terras e provocaram mudanças climáticas que resultaram não apenas no esgotamento do solo, como na erosão do terreno. Importante observar que esse ciclo de derrubada das áreas virgens, com o objetivo de ampliar as extensões cultiváveis assim como substituir as terras cansadas e improdutivas, é bem retratado no excerto acima, em que o narrador coloca que, a par das senzalas agora silenciosas, a floresta se via livre do desmatamento pelo fogo e pelo machado.

Reduzidas as áreas de mata virgem, e com a queda na produtividade em função do esgotamento das terras de plantio, os cafezais foram migrando para o chamado Oeste paulista, deslocando o eixo da produção para as novas terras. Os cafeicultores da região do Vale já não conseguiam fazer frente à concorrência paulista que dispunha de uma terra vermelha de alta qualidade - chamada rossa pelos italianos e por isso conhecida como 'terra roxa' -, e que introduz a mão de obra livre assim como novas técnicas de cultivo que evitavam a exaustão do solo.

A cultura do café privilegiava as grandes propriedades, e foi responsável pelo emprego de grandes contingentes de escravos.

Poucos municípios das diferentes áreas cafeeiras chegaram a apresentar concentrações de escravos tão altas quanto as da região fluminense: a primeira em que se desenvolveram as plantações de café antes da cessação do tráfico, a primeira a atingir o máximo da produção e também a entrar em declínio. Em meados do século, na maioria dos municípios cafeeiros localizados nessa zona, o número de escravos superava em muito a população livre. ${ }^{102}$

Mesmo com o fim do tráfico em 1850, a mentalidade escravista e senhorial impedia que se considerasse a mão de obra livre enquanto havia escravos para fazer frente às necessidades da lavoura. Além disso, com a proibição de importação houve um aumento no preço dos escravos, e com isso do patrimônio desses fazendeiros que passaram a ter uma capacidade de endividamento maior em função das garantias patrimoniais. Um aumento no crédito possibilitava, portanto, novos financiamentos, novos investimentos e endividamento. "O escravo era, além de tudo, mercadoria: mercadoria que, em caso de necessidade, podia ser vendida ou alugada, possuindo, assim, um duplo valor: valia o que

102 COSTA, Emília Viotti da. Da Senzala à Colônia. São Paulo: UNESP 4ạed. 5aa reimpr, p.105. 
produzia e valia como mercadoria." ${ }^{103}$ Com o passar do tempo, ao lado do esgotamento das terras e da queda de produtividade, os fazendeiros do Vale, em sua grande maioria endividados, não tinham como substituir os escravos que morriam, nem condições de instalar novos colonos.

A Abolição agrava ainda mais a situação, pois a supressão do trabalho escravo sem a respectiva indenização pelo Estado reduziu significativamente o patrimônio dos proprietários da região ${ }^{104}$, diferentemente do que ocorreu em São Paulo onde, além dos imigrantes, utilizava-se mão de obra de trabalhadores livres nacionais. Somava-se a isso a alta produtividade desses cafezais, e sua capacidade de investimento.

A retomada das atividades produtivas da fazenda do Grotão, mesmo depois de libertados os escravos, e cuja cultura recupera a pujança anterior, indica que ela não apenas sobrevive, mas recupera seu ritmo e o vigor perdido. Reafirmo aqui a força do texto, contrariando uma leitura frequente que tende a ver no romance o registro da decadência, talvez por associação com certa vertente do romance do Nordeste:

O trabalho (...) voltou a fecundar os campos e as colinas com suas plantações opulentas, com seus arbustos quase negros pejados de frutos sumarentos e rubros.

Luiz Costa Lima que também identifica a sobrevivência do Grotão, o faz em perspectiva diversa da proposta nesse trabalho. Para o crítico,

\footnotetext{
A destruição da fazenda não atingirá o estatuto dela, a ordem que a possibilita e onde ela se inclui. Os personagens morrem, fogem, voltam enlouquecidos, os escravos são alforriados e vagam aterrorizados. Carlota permanece como uma viva-morta, mas todo esse movimento não afeta a existência mesma da fazenda, por assim dizer condenada a sobreviver. ${ }^{105}$
}

Ele fala da retomada das atividades da fazenda que, apesar de tudo, sobrevive, caracterizando o desenvolvimento de um capitalismo precário, que não se dá pela acumulação progressiva dos meios e conquistas, mas por sua destruição. Desse processo

\footnotetext{
103 Ibidem, p.72.

104 “Em Vassouras, a 20 de março de 1888, dois meses, portanto, antes da Abolição, houve uma assembleia de fazendeiros da região para discutir a ameaça de abolição que os últimos acontecimentos pareciam tornar iminente. (...) Reunidos os fazendeiros, todos concordaram que a abolição era necessária, divergindo apenas quanto ao modus faciendi. Sobre um ponto, entretanto, não havia discrepância, a saber, que ela deveria ser acompanhada de indenização". COSTA, Emília Viotti da. Da Senzala à Colônia. São Paulo: UNESP 4ạed. 5á reimpr. p.264.

105 Cf. LIMA, Luiz Costa O romance em Cornélio Penna. 2a.ed.revista e modificada. Belo Horizonte: UFMG, 2005, pp.31-32.
} 
resultaria, segundo o crítico uma "forma de exploração capitalista (...) que persiste além de sua degradação".

Na versão anterior do livro, Costa Lima acrescenta: “Em linguagem de José Lins do Rego, será um fogo morto que não deixa de queimar"106. A recuperação dessa menção justifica-se na medida que ajuda a esclarecer o enfoque do crítico, para quem a propriedade sobrevive apenas, em estado agônico, o que contraria a própria imagem do texto, que indica uma retomada ativa da produção.

Muito embora a negatividade e o tom lutuoso impregnem a narrativa - e ultrapassem em muito a morte da menina que dá início à trama - e que a desagregação da família, que poderia ser pensada como representação metonímica da sociedade, como em $A$ Crônica da Casa Assassinada ou em Fogo Morto contribuam para a identificação do romance como da decadência de um mundo então em transição, não é sob essa perspectiva que o romance se coloca.

Não se trata da representação de um modo de resistir a uma nova configuração política, econômica ou social, como acontece no romance maior de José Lins do Rêgo. Ali tudo fica estagnado por não se adequar à chegada das usinas e das novas tecnologias que se opõem à antiga estrutura dos engenhos, caracterizando uma sociedade que já não tem mais lugar, e em que os personagens, apegados àquelas estruturas em desaparecimento, se configuram como fantasmas de outra ordem social.

O Grotão, apesar da angústia que domina os personagens, não vive a dimensão de um tempo já passado. Não se apresenta a experiência de um mundo que se desagrega pela ação da história, pela crise do mundo patriarcal, mas a da recusa deliberada, no sentido de interrompê-lo pela morte e pela destruição ao qual, no entanto, resiste.

Parecia-lhe agora que em seu luto onde se reuniam tantas recordações mortais, lançava também irremediável maldição sobre a terra pisada e varrida por seus crepes. (...) Lá no alto, para trás, os corvos iniciavam longa e aérea dança fúnebre. $E$ à medida que se aproximavam do Grotão Carlota sentia aumentar a alegria de seu corpo (...) Olhava com triste prazer o caminho áspero e cheio de flôres mortas que se engolfava sob os seus pés e eram por êles esmagadas, e sentia bem que elas eram o sinal bem certo do abandono em que tudo caíra. $O$ atalho que encurtava o caminho

${ }^{106}$ Idem. A perversão do trapezista: O romance em Cornélio Penna. Rio de Janeiro: Imago, 1976, p.36. 
para o portão do quadrado devia estar sempre livre e varrido diàriamente, mas agora adquirira o aspecto de vereda conduzindo a taperas abandonadas ${ }^{107}$.

E apesar dos farrapos como que salpicados de sangue, das flores mortas, esmagadas pelos seus pés e dos corvos que se aproximam e que remetem à morte e à ruína, a fazenda ressurge. Carlota tenta pôr fim, portanto, àquela realidade, disseminando a destruição e a morte de uma estrutura que trazia em si valores que a seus olhos não se sustentavam, mas a vida da propriedade se refaz, lentamente no início, e acabando por exibir grande vigor, em um mundo que, mesmo transformado, parece se reproduzir.

Esse desacordo com a história e com a precisão com que outros acontecimentos históricos são representados, ao lado de um relato minucioso do cotidiano e da vida privada na fazenda provocam no leitor a indagação sobre a perspectiva sobre a qual o texto é construído. As questões existenciais, assim como as de ordem metafísica que se explicitam em diversos momentos, reforçam ainda esse questionamento. É o caso, por exemplo, quando o narrador fala do destino de Carlota:

Refugiada no silêncio como a única solidão possível, ela compreendia agora a linguagem de sua casa e dos objetos que a compunham, na impossível reconciliação consigo mesma, na transposição de seu eu diante da eternidade de Deus, protegida por sua vontade que aceitara as suas próprias dimensões.

Transformar o Grotão em um microcosmo da sociedade brasileira na época do Império, evidenciando as relações que se estabelecem entre proprietários, agregados e escravos, assim como dentro de cada um dos grupos sociais, com base em uma narrativa lacunar e desfocada, para além de reforçar a verossimilhança do mundo narrado, parece repor a relação entre história e literatura, sobretudo se pensarmos que o momento em que o autor escreve é um momento em que a adesão ou o distanciamento da literatura em relação à matéria histórica está na ordem do dia ${ }^{108}$.

De um lado, uma produção literária voltada à consideração de questões sociais e históricas, com o romance de 30 que se coloca como instrumento de descoberta e de interpretação do país; de outro, a busca de um rigor esteticista da chamada Geração de 45

\footnotetext{
107 PENNA, Cornélio. A Menina Morta. In: Cornélio Penna Romances Completos. Rio de Janeiro, José Aguilar, 1958, pp.1287-1288.

108 Cf. Antonio Candido. "Literatura e Cultura de 1900 a 1945”. In: Literatura e Sociedade: Estudos de teoria e história literária. 8.ed. São Paulo, T.A.Queiroz, 2002.
} 
que, se não visa à autonomia da forma, utiliza um conjunto de convenções clássicas com tendência a se afastar dos temas sociais.

Podemos pensar que, da mesma forma que a Lírica se volta a aspectos mais formais ao indagar sobre a natureza da Literatura e sua especificidade, em um momento em que a divisão do trabalho intelectual provoca um deslocamento da posição central até então ocupada pela Literatura na vida intelectual brasileira ${ }^{109}$, o autor esteja propondo redefinir sua especificidade, inclusive na sua relação com a História. Nesse sentido, e nos moldes propostos por Aristóteles ${ }^{110}$, estaria não só reafirmando a distinção entre os dois campos, como a superioridade da Literatura em relação à História, extraindo do evento particular uma universalidade de forma verossímil e em acordo com a realidade criada pelo texto, sem se ater ao evento histórico propriamente dito.

As relações sociais, no entanto, ocupam um lugar distinto das outras questões históricas. O relato sobre a escravidão tanto na intensidade com que é referida, como na importância que assume como um dos eixos que estruturam a narrativa, pode ser entendido não só por constituir a base econômica e social de então, como pelos seus reflexos e desdobramentos, que marcam nossa sociedade atual.

Presente tanto nas atividades produtivas da fazenda como na esfera doméstica, a escravidão é representada no romance de forma contundente, assim como as relações que ela engendra. O narrador explicita tanto o controle a que os escravos eram submetidos, a violência com que eram punidos e ameaçados, a heterogeneidade da composição da escravatura, o desenraizamento que lhes era imposto, o preconceito com que eram vistos, a religião que tinham que seguir, os casamentos e as separações a que eram obrigados, como os hábitos alimentares, a forma como se vestiam e, principalmente, o arbítrio do proprietário, a quem cabia não só a decisão de recompensar ou punir, como a de vida e morte. Ao mesmo tempo, problematiza as relações de favor do ponto de vista dos que são acolhidos, as questões com que se deparam no cotidiano, seu não-lugar, a situação de absoluta subserviência a que são submetidos, e a assimilação dos valores daqueles que os

\footnotetext{
${ }^{109}$ Ainda de acordo com o ensaio acima citado.

${ }^{110}$ Cf. Aristóteles. Poética. Trad. Eudoro de Sousa. Imprensa Nacional - Casa da Moeda F.C.S.H. da Universidade Nova de Lisboa, [s.d.], pp.115/116.
} 
acolhem, assim como o comportamento e as relações da família nuclear e do próprio patriarca, já que para além das questões de classe, haveria ainda a da dominação da mulher, de quem se esperava um comportamento submisso, conforme análise posterior.

Focalizando a vida do interior da casa-grande, temos a representação do comportamento dos moradores, de seus costumes, da forma como se relacionam e dos produtos que consomem, o que faz com que o leitor se aproxime do dia a dia das grandes propriedades na época do Império, e da sociabilidade que ali se estabelece. Mas é ao revelar a interioridade dos personagens, que se evidencia como a história se conjuga aos dilemas pessoais dos moradores.

Este olhar, não apenas rico em pormenores mas um olhar de dentro, em alguns momentos parece mesmo apresentar aquele modo de vida sob uma perspectiva etnográfica, como no caso da descrição de alguns processos de fabricação importantes na economia doméstica, como o da preparação da tinta para tecidos, o do azeite de mamona para os candeeiros, do doce de goiabas em calda e mesmo do caixão para enterrar a menina, indicando a autossuficiência de um núcleo isolado.

Mesmo quando se apresentam objetivamente os acontecimentos, estes aparecem subordinados à percepção que os personagens têm da realidade em que se encontram. Ao descrever a fabricação do azeite para as lamparinas da casa, por exemplo, o narrador começa dizendo que a cozinha "lembrava a sala subterrânea de convento antigo" e o teto parecia imensa abóbada negra. Compara ainda o som da fervura das sementes de mamona a um murmúrio, igual à conversa misteriosa de muitos negros lá na senzala quando tramavam alguma coisa má e depois "à conversa dos diabinhos escondidos embaixo daquelas águas revoltas (cuja) agitação bem demonstrava como deviam se digladiar os coitados que estavam lá no fundo", remetendo claramente à imagem do inferno como um caldeirão de óleo fervente, impressão que poderia ser atribuída a qualquer dos personagens, tendo em vista a apreensão permanente em que vivem, seja com relação aos outros moradores, seja de forças transcendentes. 
Embora se trate de um tempo que o autor não viveu, e que só experimentou indiretamente pelas histórias que ouvia, ele recria o ambiente como se quisesse adentrar a vida de seus antepassados ${ }^{111}$, num jogo de memória e invenção.

Mas o que provoca o leitor é o fato de não existir distanciamento nesse olhar que, em meados do século $X X$ se volta para um século antes, nos remetendo àquele momento $e$ àquele espaço como se falasse dali, e não como memória, fazendo com que o tempo da narrativa se colasse ao tempo narrado.

111 Parece esclarecedora a declaração que o autor faz a João Condé, ao falar do processo de criação de Repouso. "Repouso viveu sempre dentro de mim, escondido, guardado, mas latente e bem doloroso e vivo, pois, desde que me conheço, ouvia as histórias de Itabira, de Pindamonhangaba e das fazendas de meus avós e tios, contadas de forma interrompida, desconexa, cercadas pela mais suave discrição que já me foi dado encontrar, contadas por minha mãe. Eu guardava tudo com avidez, sem demonstrar como era funda a emoção que me provocavam aqueles episódios sem uma ligação aparente entre eles, que eu recolhia e depois ligava com um fio inventado por mim. (...) Depois, uma parenta de Itabira veio de novo para me contar as mesmas velhas histórias, mas já agora com vida, com sangue, no tumulto de sentimentos que se agitavam de todo aquele silêncio, de toda aquela serenidade endolorida das conversas tão misteriosamente doces do regaço materno. Para me livrar dela, para desabafar a compreensão devoradora que me fazia perder noites inteiras, pensando no que tudo aquilo representava de verdadeiro Brasil, de humanidade muito nossa e palpitante, eu comecei, por minha vez, a contar aos meus amigos o que sabia e os sentimentos que me provocavam, e lhes pedia que escrevessem sobre a alma de Itabira, que resumia a do Brasil, que tão ferozmente se destrói a si mesma, deixando perder-se um tesouro preciosíssimo. Mas... era ouvido com espanto, ou então com o desdém que vi uma vez nos olhos e na boca de Raul Bopp, ou, o que era pior, com incompreensão e outras interpretações, que transformavam minhas pobres histórias em anedotas de pequena cidade. Foi então que resolvi deixar de lado o desenho, que não me satisfazia e me levava a crer que era um literato que pintava, e tentar escrever o que vivia em mim com tanta intensidade, com os problemas e os caminhos que se apresentavam à minha frente." FILHO, Adonias. "Os romances da humildade". In: Cornélio Penna Romances Completos. Rio de Janeiro, José Aguilar, 1958, p.XXXIX/XL. 


\section{Sobre a construção da narrativa}

A narrativa começa em meio à ação, com os preparativos do enterro da filha mais nova dos proprietários da fazenda. Diferentemente de grande parte das narrativas que começam in media res, em A menina morta não há retrospectivas que possibilitam ao leitor compreender as causas e circunstâncias de tal evento.

Há comentários sobre acontecimentos passados, mas estes parecem ter antes como função adensar a narrativa do que esclarecer as motivações dos personagens. Assim, os relatos de fragmentos do passado de alguns deles, sobretudo dos escravos e agregados antes de sua chegada à fazenda, remetem a dramas pessoais que ajudam a compor a realidade social e econômica a que estão ligados, assim como ilustram a lógica da escravidão, mas deixam lacunas na trama que constitui a obra. Sobre o passado da fazenda ou dos seus proprietários, as poucas referências são permeadas de não ditos que criam um ambiente de mistério e deixam o leitor à margem dos acontecimentos, como o que acontece com relação à história da família da Senhora e a um suposto crime em que alguns de seus membros estiveram envolvidos.

Mas os vazios do texto não se limitam ao que precede os acontecimentos que dão início ao romance, e estendem-se àqueles em curso no tempo da narrativa, como é o caso da partida de D. Mariana da fazenda, ou o que se passa enquanto ela está fora, de onde retorna insana.

Sobre as circunstâncias da morte da menina também nada se sabe, assim como da sua idade ou nome. Importante observar que os únicos personagens apresentados pelo nome são D. Mariana e seus filhos, com exceção da menina, os agregados, os escravos de dentro e os que prestam serviço na casa-grande. Aqueles que representam o poder são conhecidos apenas por seus títulos, o que Ihes confere distinção social e indica que o que os designa é a posição de poder que ocupam: Comendador, seu irmão Visconde, ou a prima Condessa. Importante lembrar que, embora os títulos não tenham tido no Brasil nenhum estatuto jurídico próprio, serviam como forma de distinção social e legitimação de poder local. 
"O Segundo Reinado não se compreenderia sem os barões, coronéis, comendadores e conselheiros. A imensa rede de títulos, comendas e patentes doura a sociedade" ${ }^{112}$, tingindo de nobreza um rigoroso mecanismo de coesão de forças.

Com relação à menina, que como já dito não é referida por um nome, ela se constitui antes como função do que como personagem. Para Vecchi, que igualmente identifica a questão da designação dos personagens ${ }^{113}$, ela estaria no centro da construção do "contramito" da democracia racial proposta por Freyre. O crítico italiano considera que há uma "contranarrativa" subjacente à obra que se opõe ao mito da confraternização entre as raças de Casa-grande e senzala, que expõe o trágico do movimento de formação do país.

Ao remitificar a obra de Freyre, que inaugura em 1933 os grandes ensaios de interpretação dos dilemas da formação nacional brasileira e que exprimem, no campo da investigação histórico-sociológica, as tendências do Modernismo traduzindo sua busca de redescoberta do país, Cornélio Penna estaria fazendo com que

A menina morta se inscrevesse em relação ao Modernismo numa condição de exceção, sendo ao mesmo tempo dentro e fora, incluindo e excluindo os contributos fundamentais decorrentes da articulação de autoconsciência moderna do país semiperiférico ${ }^{114}$.

Luiz Costa Lima também contrapõe as duas obras em função do sentido contrário com que configuram a experiência da escravidão, e levanta a ressalva referente às dificuldades que advêm da comparação de obras inscritas em formações discursivas tão diversas, como um tratado de história social e um romance, considerações compartilhadas por Vecchi. Na versão em que revisa a primeira edição de seus estudos sobre o autor, Costa Lima propõe que essas dificuldades podem ser superadas ao serem "comparadas a partir de um terceiro termo: o mito, que em feições opostas, as duas configuram". Enquanto Casa-

\footnotetext{
${ }^{112}$ Cf. FAORO, Raimundo. in: Machado de Assis; a pirâmide e o trapézio. 4ạed. rev, 1a reimpressão. São Paulo: Globo, p.40. "As antigas ordens portuguesas, nacionalizadas e transformadas, e as ordens novas brasileiras provocaram uma derrama de condecorações. No mesmo pé dos conselheiros, proliferavam os comendadores, superiores em grau aos oficiais e cavaleiros, (...). Honrarias (que) premiavam serviços prestados ao Estado", p.47.

${ }^{113}$ Cf. Posfácio. Autópsia da casa-grande, p.537.

${ }^{114}$ Cf. Posfácio. Autópsia da casa-grande, p.550-553.
} 
grande contribuiria para o mito do congraçamento das raças no Brasil, Cornélio Penna faria com que a matéria mítica assumisse "a feição contrária à do mito constituído". ${ }^{115}$

Não podemos deixar de considerar que ao lado da crítica à visão idílica do nosso passado colonial e de um quadro mistificador do processo de miscigenação subjacentes à leitura de Casa-grande e Senzala, desenvolve-se outra linhagem que tem proposto uma reavaliação da visão edulcorada da colonização, e que tem como expoente a obra de Ricardo Benzaquen de Araújo na análise das obras de Freyre produzidas na década de 30.

Para o crítico, o mito da democracia racial não desconsidera a violência entre casagrande e senzala, e defende que o intenso convívio entre brancos e negros apontado na obra de Freyre teria criado um ambiente que envolveria heterogeneidade, proximidade, despotismo e confraternização.

Da mesma maneira que encontramos em CGS um vigoroso elogio da confraternização entre negros e brancos, também é perfeitamente possível descobrirmos lá numerosas passagens que tornam explícito o gigantesco grau de violência inerente ao sistema escravocrata, violência que chega a alcançar os parentes do senhor, mas que é majoritária e regularmente endereçada aos escravos. Assim, desde o prefácio, (...) podemos perceber que, apesar da mestiçagem, da tolerância e da flexibilidade, o inferno parecia conviver bem com o paraíso em nossa experiência colonial. ${ }^{116}$

Baseando-se no conceito de "antagonismos em equilíbrio", Benzaquen defende como ponto central da sua reflexão um argumento fundado na ambiguidade e na particularidade, afirmando que:

assim como as distintas influências étnicas e culturais conseguiam combinar-se separadamente no português, a violência e a proximidade sexual, o despotismo e a confraternização familiar parecem também ter condições de conviver lado a lado, em um amálgama tenso, mas equilibrado. ${ }^{117}$

O modo como se configuram esses antagonismos desvendaria ainda a noção de Cultura em Gilberto Freyre que combinaria, de maneira plástica e híbrida, sem qualquer desejo de síntese, as mais diferentes tradições e indicaria que a miscigenação não dissolveria as particularidades.

\footnotetext{
${ }^{115}$ Cf. LIMA, Luiz Costa. O romance em Cornélio Penna, pp.16-21.

${ }^{116}$ Cf. ARAUJO, Ricardo Benzaquen de. Guerra e Paz - Casa-grande \& senzala e a obra de Gilberto Freyre nos anos 30, pp.45-46.

117 Ibidem, p.54
} 
Mas para além da discussão das considerações da crítica sobre as posições da obra de Freyre que esse trabalho não pretende explorar, e sem desconsiderar a importância do testemunho histórico que $A$ menina morta transfigura, assim como a impossibilidade que a narrativa atesta da conciliação do mundo da casa-grande e o da senzala, me parece importante destacar algumas formulações presentes no texto que remetem a teorias raciais de meados do século XIX às quais Freyre já se opunha.

Em meio a uma narração contundente da escravidão, transparece no discurso do narrador uma perspectiva racial que denota a "inferioridade" do negro, colocando-o como uma espécie de sub-raça que retoma teses do determinismo naturalista.

\begin{abstract}
O cocheiro, ao ouvir aquela voz imperiosa, não considerou que partia da prima sem importância, que via sempre andar como uma sombra sem sol pelos cantos da casa, sem que ninguém a visse ou ouvisse, sem que sequer interceptasse a vista dos que conversavam, e se dirigiam uns aos outros sem olhá-la. Pôs o chapéu na cabeça e subiu agilmente para o banco da direção, como um macaco ensinado, e sua japona flutuou por instantes, sacudida pelas brisas do vale do grande rio.

(...) Celestina seguiu (o trintanário) com o olhar, que se tornara límpido, pois as palavras de $\mathrm{D}$ a.Virgínia a tinham chamado a si mesma, à sua condição de protegida, $\mathrm{e}$ viu-o aproximar-se de cada caleça, chamar o ajudante de cocheiro de cada uma, e dizer-lhe alguma coisa, com o primitivo gesticular dos de sua raça ${ }^{118}$.
\end{abstract}

Em outra passagem ele comenta como reage Ângela, a mucama da Senhora, ao perceber ser do cavalo o barulho do que lhe pareceu a princípio uma gargalhada louca e sobre-humana: "A mulata riu-se do medo que a fizera vibrar com a intensidade dos de sua raça" ${ }^{119}$. Ou ainda quando fala da velha negra encarregada da costura, nascida entre "selvagens antropófagos", cujo coração era, entretanto, o mesmo que batia "naqueles outros peitos suavizados pela mistura de sangue branco"120, o que remete não só à barbárie, à situação primitiva e incivilizada do negro africano, como ao abrandamento da sua rudeza quando fruto do cruzamento com o branco, que implica uma perspectiva evolucionista da mistura de raças.

Ao aprimoramento e depuração associados à tese de branqueamento, e vinculados à ideia de superioridade racial, há ainda outras indicações que remetem a certa herança

\footnotetext{
118 PENNA, Cornélio. A Menina Morta. In: Cornélio Penna Romances Completos. Rio de Janeiro, José Aguilar, 1958, pp.771-772.

119 Ibidem, p.890.

120 Ibidem, p.822.
} 
naturalista, como quando compara a fazenda ora a "grande colméia rural" ${ }^{121}$, ora a grande animal adormecido, assim como os gestos do fazendeiro à "poderosa agilidade de animal sadio" 122 .

Importante observar ainda nos excertos acima a posição do narrador, problemática ou problematizada, pois embora onisciente, cria ambiguidades narrativas, parecendo se ocultar na fala dos personagens, conforme apontado adiante.

Ao proibirem a celebração de qualquer homenagem fúnebre ou manifestação de pesar pela morte da filha, os senhores impedem a elaboração do luto e fazem com que a esperança que ela evoca em vida se transforme em símbolo. Nesse sentido, o retrato encomendado pelo Comendador parece ter menos o objetivo de imortalizá-la na memória do grupo do que instaurar seu culto, de modo a confluir para a sua figura a projeção das frustrações e dos sentimentos de falta de todos. Em outras palavras, a imagem de sua morte legitima um meio dos personagens canalizarem suas dores, pois impede que eles tenham a consciência do objeto da perda e o nomeiem, de forma a circunscrevê-lo ${ }^{123}$. Importante lembrar que quando se acerta o casamento de Carlota, como se já tivesse cumprido seu propósito, o quadro é retirado.

Marcado por silêncios e por um relato fragmentado que omite deliberadamente passagens importantes da trama, o texto traduz a interdição e as relações de poder e de hierarquia ali engendradas. É, portanto, um silêncio que fala. Inúmeras reticências, insinuações e subentendidos exprimem as frases inacabadas e os gestos incompletos daquele grupo de moradores, marcado pela incomunicabilidade e pelo medo, em um mundo sem lugar para qualquer manifestação de espontaneidade ou qualquer confidência que denote intimidade ou cumplicidade. O autoritarismo que impera na fazenda faz com que cada um aja de acordo com o que julga mais adequado ao seu papel social, e se feche na sua própria interioridade.

\footnotetext{
121 Ibidem, p.944

122 Ibidem, p.748

${ }^{123}$ Cf.. Freud, S. Trad. Marilena Carone. Cebrap - Ver. Novos Estudos, n. 32 - março de 1992. Esse comentário baseia-se na leitura do texto "Luto e Melancolia" em que Freud faz considerações a respeito da natureza da melancolia comparando-a com o estado de luto, em que há perda do objeto amado.
} 
Mas o autoritarismo não domina apenas os personagens. Ele atinge também o leitor, submetido a uma narrativa que sugere sem explicitar. Aos acontecimentos interpõemse cenas e personagens que não retomam os acontecimentos anteriores, e assim vai sendo tecida a trama da narrativa, que não é clara em relação ao que se passa. O leitor é como que igualado aos personagens que só têm conhecimento de fragmentos do que ocorre à sua volta. Cabe a ele, então, fazer conjecturas, apreender aos poucos a situação, ou ignorá-la por completo, o que reforça o efeito de abafamento criado pelo texto.

Vecchi sintetiza, com propriedade, que "a retenção da comunicação que experimenta o leitor é de certo modo metonímica em relação ao regime de interdição que reina no Grotão, como se a própria narrativa tivesse internalizado o jogo de poder dominante"124. Daí a importância de se atentar para as diferentes formas de representação do texto, que se desdobram não só no que é dito, mas no modo como é dito.

Se pensarmos que uma das questões colocadas no romance é a da anulação do Outro, seja pela coisificação, seja pelo regime de favor ou pela sujeição das mulheres e filhos ao poder patriarcal, transformar o leitor em duplo dos personagens seria uma forma de submeter o leitor, o Outro do texto, a uma experiência que mimetiza a interdição.

No mesmo sentido, o controle da narrativa, a contenção com que o narrador apresenta os acontecimentos, traduzem o controle e a austeridade do ambiente narrado. Não há paixões, envolvimento ou adesão, e o próprio relato da escravidão exige atenção do leitor para desvendar o grau de crueldade que ele abrange. Por mais violenta que seja a cena, por mais ilustrativo ou sórdido o comportamento de algum personagem, ele aparece sem a devida força, e faz com que o texto exija um leitor atento aos detalhes. É o que vemos, por exemplo, quando as negras solteiras esperam alguém vir abrir o portão para que elas possam ir até a igreja rezar pela menina. Em meio à plasticidade da cena que opõe as roupas brancas das escravas aos seus braços negros, um grupo de mulheres de idades e nações diversas alinhadas às trouxas de roupa em um canto, observa o narrador:

O feitor devia ainda estar deitado e elas contavam sair com a licença do administrador que uma delas tinha obtido, pois queriam visitar a igreja onde a menina fôra enterrada...

\footnotetext{
${ }^{124}$ Cf. Posfácio. Autópsia da casa-grande. p.539.
} 
Mas não tinham sido até aquela hora abertas as portas do quadrado e estavam prisioneiras. Alguém dissera que viria abri-las bem cedo e cobrara de antemão o preço dessa promessa, porém tardava, e nenhuma delas ousava reclamar $^{125}$.

O mesmo se dá na passagem em que o Comendador, na noite mesma do enterro da menina e depois de todos terem se recolhido, sai silenciosamente pelo alpendre em direção à senzala das mucamas e desaparece na escuridão, conforme apontado adiante.

Até o que é evidenciado, algumas vezes não é explicitado com clareza e suscita em quem lê um sentimento de indefinição com relação ao que está sendo dito. É o que ocorre, por exemplo, em uma passagem em que a Senhora retorna para casa:

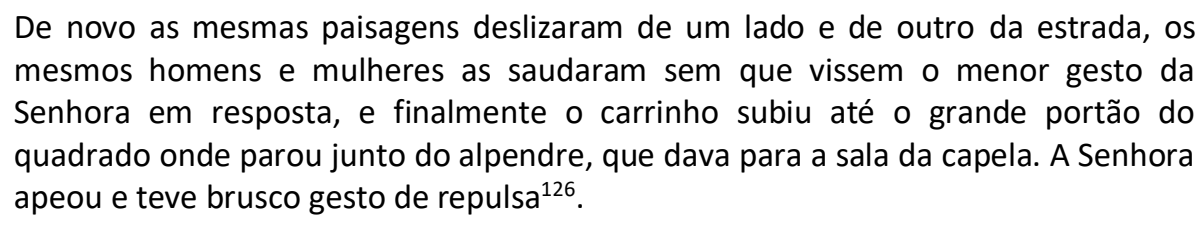
De início supomos que sua repulsa se refere à realidade cotidiana da fazenda, tendo em vista que ela se recusa a passar pelas plantações, e faz com que o cocheiro desvie o caminho quando os escravos estão trabalhando. No entanto, quando introduzido o detalhe da capela, parece que se abre outra possibilidade. Ela poderia estar recusando uma religião institucionalizada que não reconhece como legítima, um santuário forjado que se opõe ao verdadeiro santuário que fica na clareira da mata, justamente de onde ela está vindo, e que levanta outra questão para a qual o romance aponta: a inobservância de práticas religiosas e de culto, sobretudo por parte dos proprietários, como se na ausência do sagrado vigorasse a violência e os interesses pessoais.

Mas dentre as inquietações que o texto provoca, está também o fato de o narrador ser onisciente e ao mesmo tempo omitir acontecimentos e motivações dos personagens. Se ele é onisciente e, assim sendo, em princípio não desconhece nada, porque omite fatos ou motivos? A suposição do caráter funcional dos silêncios e da indefinição que permeiam a narrativa aumenta ainda quando observamos a representação minuciosa com que o autor "inventaria" a vida social da fazenda, conforme apontado anteriormente. Importante observar que essa representação não constitui apenas a moldura, o ambiente em que se

\footnotetext{
${ }^{125}$ PENNA, Cornélio. A Menina Morta. In: Cornélio Penna Romances Completos. Rio de Janeiro, José Aguilar, 1958, p.799

126 Ibidem, p.891
} 
desenvolvem os dramas íntimos dos personagens, pois a "realidade" em que estão inseridos está intimamente ligada às relações humanas que se estabelecem entre eles e à sua caracterização social e individual.

Além disso, e conforme observado anteriormente, a presença do narrador entre o leitor e a história nem sempre se evidencia de forma clara. A história apresenta-se, em grande parte, a partir de situações dramatizadas diretamente pelos personagens e por suas impressões, que ele media sem qualquer interferência ou comentário. Não se trata, no entanto, de uma onisciência neutra ${ }^{127}$, já que essa se caracterizaria em função de uma objetividade que não tem lugar no texto. Os acontecimentos, e mesmo as descrições, apresentam-se a nós, leitores, de forma subjetivada. Em meio à monotonia da vida dos moradores da casa-grande, os poucos acontecimentos não figuram de forma a dar andamento à ação. Eles importam apenas pelo modo como ressoam na consciência dos personagens. Em outras palavras, o narrador controla a narrativa, atendo-se a circunstâncias cotidianas que pouco fazem com que a ação avance, e opondo à escrita longa e abundante uma ação reduzida. A escrita incorpora assim o ritmo tedioso da vida no Grotão, fazendo com que uma das linhas de força do romance seja a incorporação do conteúdo na forma.

Se atentarmos para algumas das descrições do romance, observamos que ao lado daquelas mais objetivas, que constroem uma representação minuciosa das relações sociais e dos costumes de então, há outras que interferem subjetivamente na percepção do leitor, indicando não só o que ver, mas como ver.

Não podemos negar também que há uma relação entre linguagem literária e imagem pictórica que permeia o texto, e que supomos ser reforçada pela própria trajetória do autor, em função do olhar que desenvolve com a pintura e o desenho. Sabemos que só em 1928 Cornélio Penna passa a dedicar-se à literatura, pois não se considerava "nem pintor, nem desenhista, nem ilustrador e via em seus trabalhos literatura desenhada". Ao atentarmos, mesmo que rapidamente, a sua produção como desenhista e pintor, podemos observar o que ele mesmo declara ao subordinar as formas plásticas à literariedade, dada a força de mensagem que elas contêm.

\footnotetext{
${ }^{127}$ Seguindo a tipologia de Norman Friedman, apresentada em $O$ foco narrativo (ou a polêmica em torno da ilusão), de Lígia Chiappini Moraes Leite. 6ªed. São Paulo: Ática, 1993, que serviu de base para a caracterização do narrador na qual se baseia esse trabalho.
} 
No entanto, algumas descrições parecem ir além do efeito pictórico que criam, e provocam o leitor, ampliando o impacto da cena ao evocar essas imagens mentais. As cenas da ida do senhor à senzala, e da tentativa das escravas de visitarem a igreja após o enterro da menina foram as que me pareceram as mais emblemáticas desse procedimento. No entanto, privilegiarei aqui a primeira delas, tendo em vista que a cena do cortejo das escravas, descrito através da imagem fabulosa da marcha determinada de um dragão que se dissolve diante da aproximação dos feitores, será contemplada ao tratar da representação dos escravos.

A saída do Comendador da casa na noite do enterro da menina quando todos já estavam recolhidos traduz ao mesmo tempo a legitimação da transgressão e autoritarismo do senhor, e o movimento sutil daquelas mulheres anônimas e indefesas diante da aproximação de um caçador implacável.

... ergueu o busto com energia e caminhou para a porta que dava saída para o quadrado da fazenda com passagem pelo alpendre. Depois de apagar a vela e colocar o castiçal no chão fêz fogo com grande isqueiro tirado da algibeira do casaco que ainda vestia e apanhou rapidamente uma lanterna de furta-fogo ${ }^{128}$, habitualmente guardada debaixo do banco de ferro que ali havia, decerto para essas ocasiões, e com ela oculta pela própria roupa desapareceu na escuridão.

Apesar do silêncio e da paz profunda que reinava no terreiro calçado de grandes lajes branquicentas, apesar da noite espessa que por ele se estendia, vultos tão negros como ela movimentaram-se sutilmente e espreitaram escondidos pelas grandes colunas de madeira feitas de tronco de árvores enormes apenas desbastadas pela enxó dos carpinteiros cativos e que formavam a varanda do lado da senzala das mucamas. Parecia soturno bailado muito leve, em que as aves noturnas tomassem parte, ou seus protagonistas estivessem fantasiados de veludo preto, com sandálias de lã e fugissem de um lado para outro em corridas ágeis e silenciosas. Muito de longe, vindo da mata próxima, a subir o espigão perdido da serra do Mar que formava o fundo do altiplano onde estava a fazenda, veio então, trazido pelas lufadas de vento morno do início da noite, o bater surdo dos tambores, talvez de algum quilombo, onde os negros sentissem necessidade de desafiar os capitães do mato, indicando assim a sua presença nos longínquos grotões. Imediatamente todo o movimento cessou e o negrume das trevas fez-se unido, imóvel, como se tudo estivesse à escuta de algum sinal indecifrável para os brancos, transmitido assim por aquelas batidas abafadas. ${ }^{129}$

Depois de apontar o cuidado para não ser visto, e a habitualidade do senhor que pega uma lanterna dotada de um mecanismo que ocultava a luz sem apagá-la, deixada sempre debaixo

\footnotetext{
128 Segundo Dicionário Houaiss, diz-se de lanterna portátil munida de dispositivo, ger. placa corrediça, que permite ocultar a luz sem a apagar.

129 PENNA, Cornélio. A Menina Morta. In: Cornélio Penna Romances Completos. Rio de Janeiro, José Aguilar, 1958, pp.787-788
} 
do banco "decerto para essas ocasiões", o narrador coloca em cena a aproximação do Comendador da senzala e o movimento que ele provoca junto às mucamas. Tudo se passa como na apresentação de um teatro de sombras ${ }^{130}$, em que as imagens não se mostram de modo claro, e em que as figuras ficam à espreita ou correm, ágil e silenciosamente, de um lado para o outro. Mais que de figuras, trata-se de vultos anônimos que, como diz o narrador, parecem bailar contracenando com aves noturnas, o que por si já remete à ideia de animais de rapina, caçadores silenciosos e eficientes, de cuja aproximação as escravas parecem tentar se esquivar. O narrador qualifica a cena, portanto, remetendo a imagens que dizem sem dizer. Intercala ainda na sua descrição comentários que reforçam o trabalho dos escravos como pilar daquele sistema, pois são eles os responsáveis pela construção das colunas que sustentam a varanda. Interessante observar como, imediatamente depois, e ainda no mesmo parágrafo, o narrador desloca o olhar para o som dos tambores trazido pelos ventos de algum quilombo da redondeza. Esse som, associado a um sinal indecifrável pelos brancos, anuncia uma das formas de resistência dos negros, parecendo relembrar sua única resposta possível. Mas apesar da relevância da questão, o discurso do narrador não denuncia a importância do tema, que apenas cita de passagem em meio à cena do assédio do senhor junto às escravas, utilizando-se de um recurso de "esfriamento" da narrativa, já mencionado e que procuro desenvolver logo adiante.

Pelo modo como é 'dramatizada' essa descrição, pelos efeitos que a composição da imagem provoca no leitor, levantamos a hipótese do uso da ekphrasis, entendida aqui como procedimento que amplifica a descrição, e não como representação verbal de representações visuais ${ }^{131}$. Um enunciado que cria uma imagem que provoca efeitos

\footnotetext{
${ }^{130}$ Simone Rossinetti Rufinoni também aponta para a analogia da cena com um teatro de sombras, embora o faça em outra chave, pois enfoca os escravos como espectros, sombras sem corpo e sem voz, que ecoam a presença oculta do trabalho. Favor e Melancolia: Uma leitura de A menina morta de Cornélio Pena, p.105.

${ }^{131}$ Não há, na crítica contemporânea, um consenso quanto ao conceito de ekphrasis. Para alguns, o termo remete à representação verbal de uma representação visual, enquanto outros consideram que ela não se limita a denominar a descrição literária de um objeto das artes plásticas. A etimologia da palavra (de phrazô, "fazer entender", e ek, "até o fim") indica seu significado como "exposição" ou "descrição", associada a técnicas de amplificação de tópicas narrativas. Utilizada na Antiguidade como artifício retórico, consistia em uma descrição virtuosa com o intuito de evocar uma imagem mental no ouvinte tão intensa como se o objeto real descrito estivesse perante seus olhos. O termo também nomeia um gênero de discurso epidítico praticado como exercício de eloqüência ou declamação por filósofos e oradores da chamada "segunda sofística" do século II d.C.. (...), evidenciando a habilidade do orador ao descrever quadros ficcionais com vivacidade e atribuindo qualidades à imagem descrita, de modo a expor a coisa por meio da opinião sobre a coisa. Cf. João Adolfo
} 
sensoriais no leitor, que faz com que ele sinta e veja algo que não está diante dele, e que modela de certa forma o ponto de vista desse leitor. Como se a palavra procurasse um complemento que a reafirmasse, a imagem evidencia a prepotência do senhor, o domínio da sua vontade sobre as escravas, meras sombras sem identidade, vulneráveis ao seu arbítrio. Chama atenção aqui ainda outro elemento na caracterização desta figura retórica, que é a adequação da matéria tratada à representação, no caso o teatro de sombras, com sua movimentação dramática e silenciosa.

Em A menina morta, a antinomia entre uma narrativa realista com abundância de pormenores descritivos e omissões deliberadas ou informações incompletas ${ }^{132}$, ao mesmo tempo que contradiz a objetividade característica do Realismo, mimetiza o ambiente narrado, reproduzindo junto ao leitor a interdição a que estão submetidos os personagens, assim como aponta para a ambivalência da representação, um dos traços constitutivos da obra, conforme vem sendo apontado.

Ao analisar, no ensaio "Realidade e Realismo", a função dos pormenores que integram uma descrição ou uma narrativa, tomando a obra de Proust como referência a essa indagação, Antonio Candido destaca sua dupla função: a referencial e a estrutural. Enquanto a primeira dá credibilidade à existência do objeto ficcional, cria um "efeito de real" nos termos de Barthes, ${ }^{133}$ a segunda resulta do arranjo e qualificação dos elementos particulares

Hansen. Categorias epidíticas da ekphrasis. In: Revista USP, São Paulo, n.71, p.85-105, setembro-novembro 2006.

Em meados do século XX, uma parte da crítica generaliza uma acepção particular do termo, restringindo-o à descrição literária de um objeto das artes plásticas, ou como define Heffernan, "à representação verbal de uma representação visual". Seria nesse caso, portanto, um artifício de representação da representação, que permitiria a relação directa entre um medium artístico com outro, i.e., funcionaria como um género de "ponte" entre duas esferas artísticas, definindo e descrevendo as respectivas essências e formas de maneira a ilustrar um objecto artístico de forma vívida através de um medium distinto. Cf. Carlos Ceia. E-Dicionário de Termos Literários (EDTL), coord. de Carlos Ceia, s.v. 'Ekphrasis . Disponível http/edtl.fcsh.unl.pt/businessdirectory/7085/ecphrasis-/[consult. 20/04/2017]

132 Roberto Vecchi atribui a esta ambivalência uma das maiores causas do estranhamento e mal-estar que a obra provoca no leitor. Autópsia da casa-grande (a que vulgarmente chamamos Brasil). Posfácio A menina morta Cotovia, Lisboa, 2006

133 BARTHES, Roland. "O efeito de real”. In: O rumor da língua. Trad. Mário Laranjeira. São Paulo: Brasiliense, 1988. 
que, no texto, garantem a formação do seu sentido específico e a adequação recíproca das partes (coerência). ${ }^{134}$

O pormenor estabelece, portanto, ao mesmo tempo a particularidade dos elementos e a generalidade do seu significado, ou seja, revela na sua articulação uma reflexão mais profunda, um princípio integrador que vai além da sua função referencial.

Ao tomarmos o romance de Penna, em que há uma desmedida no uso dos pormenores, percebemos que ao mesmo tempo que remetem à representação de uma realidade concreta, eles conferem ao texto um sentido específico, ainda mais se considerarmos as indefinições narrativas e suspensões de sentido do texto.

Parece plausível indagar então, se o autor está evidenciando a construção do narrador como estratégia discursiva e, como tal, sujeito a manipulações mesmo quando se mostra aparentemente neutro e objetivo. Ou se está pondo em questão a onisciência, enquanto impossibilidade de se ter uma percepção totalizante ou absoluta do que quer que seja.

Mas podemos pensar também que ele esteja propondo, nas lacunas da trama, que as possibilidades ficcionais tanto do romance realista do século XIX como as do romance neorrealista são insuficientes para a compreensão daquilo que realmente importa. Nesse sentido, ao prescindir do que é contingente, ele estaria privilegiando os aspectos essenciais e atemporais que dariam sentido à obra, e que remeteriam a questões inerentes à existência, como a angústia, o sentimento de incompletude dos personagens, e as preocupações metafísicas.

Assim, se o romance não aceita o que é episódico, uma vez que não valoriza os pequenos acontecimentos, os dramas circunstanciais e particulares vividos pelos personagens, faz sentido que os acontecimentos históricos não tenham função estrutural e sejam tratados de forma ambígua.

A perspectiva do narrador, a dos que estão submetidos à opressão do sistema patriarcal, cujos pensamentos e sentimentos ele adentra, evidencia-se desde os primeiros

\footnotetext{
${ }^{134}$ CANDIDO, Antonio. "Realidade e Realismo (via Marcel Proust)". In: Recortes. 1ạ.reimpressão. São Paulo: Companhia das Letras, 1996. pp.123-129.
} 
capítulos. A caracterização dos moradores, assim como a da casa, vai sendo feita aos poucos, conforme o desenrolar da ação, através de cenas protagonizadas por diferentes personagens, o que permite ao leitor não apenas ver a estrutura de dentro, mas sob diversos ângulos.

O autor introduz a narrativa através de quadros simultâneos, que vão apresentando os personagens, e revelando como eles veem os outros e se percebem naquela estrutura de dominação, e através dos quais vai sendo criada toda a ambiência ${ }^{135}$ do romance. É como se a construção do texto fosse guiada pelo olhar.

Só a partir do capítulo $V$, quando se dá a apresentação do Comendador, proprietário da fazenda, a narrativa passa a seguir de forma linear. É bastante significativo que justamente quando ele entra em cena se opere essa mudança, pois sua dominação até então difusa se materializa, como se ordenasse também a narrativa.

Marcado por forte negatividade, o romance começa com um "Não" que uma velha escrava diz à governante, ao discordar da inadequação de um detalhe da roupa que a menina iria usar como mortalha. Chama a atenção do leitor ele ter início pela voz de uma cativa, haja vista que os negros praticamente não têm voz no desenrolar da narrativa. No entanto, e apesar do silêncio que lhes é imposto, as grandes narrativas vêm das histórias que os negros contam. São seus relatos que iluminam o pouco que sabemos sobre o passado daquela família. Assim é que Libânia rememora algumas passagens da vida da menina morta, Joviana fala da chegada de D.Mariana com a família no Grotão ainda criança, ou que Dadade, ama-de-leite da sinhá velha, denuncia o passado de violência sofrida pelos negros na fazenda dos pais do Comendador, transfigurando a história através de sua narrativa fantástica da escrava sem rosto.

Mas sem ser como testemunhos da memória da família, no dia-a-dia suas falas são descritas pelos moradores como "meia-língua" ou como sons indecifráveis, fazendo alusão a sua herança africana e a palavras de feitiçaria que assombram os brancos.

\footnotetext{
${ }^{135}$ Ambiência no sentido de conjunto de procedimentos destinados a provocar, na narrativa, a noção de um determinado ambiente, e que conferem ao espaço uma dimensão simbólica. Conforme referido em Espaço e Romance de Antonio Dimas (p.20).
} 
Contrariando o que se esperava, ao sugerir um detalhe na confeç̧ão do vestido da menina a mucama surpreende a governanta que, embora admita o bom senso do comentário, não deixa transparecer a sua concordância.

Era perpétuo absurdo aquela criatura disforme, cor de chocolate, com enormes olhos coruscantes, ora acesos ora apagados, iguais aos das aves domésticas, ter critério e tato para saber o que ficava melhor e mais elegante nos trajes confeccionados por elas ${ }^{136}$.

Sentia-se envergonhada de seguir as indicações da velha negra, e além disso escrava. A escrava por sua vez, sabendo ter desrespeitado a hierarquia ao contestar a governanta, e temendo por qualquer punição ou feitiçaria que pudesse ser feita contra ela, recorre à reza e benze-se em silêncio. Tanto as histórias sobre o país de origem daquela mulher branca como a travessia que ela havia feito por semanas para chegar ali, lhe pareciam incompreensíveis. A imensidão do oceano, que compara ao rio Paraíba em dias de enchente, mas de onde não se veem as margens, Ihe parece inimaginável assim como as terras de onde ela vinha, indicando a impossibilidade dela se imaginar fora daquele universo, e de simbolicamente, tendo em vista uma autonomia que lhe é inconcebível, fazer uma travessia individual como sujeito.

É interessante observar que, apesar de viverem todos isolados em um espaço restrito, de tal forma a interdição determina o ambiente, e é rígida a estrutura hierárquica a que estão submetidos, que os moradores não só não têm intimidade, como se veem com absoluta estranheza e parecem pertencer a mundos distintos. Enquanto a governante considera a escrava uma "criatura disforme, cor de chocolate, com enormes olhos coruscantes, iguais aos das aves domésticas" e, assim, incapaz de formular um juízo adequado sobre algo, esta última tem medo dos poderes ocultos daquela mulher branca, de olhos azuis quase cinzentos, de que emanam "raios de luz mortiça de estranha fixidez".

Sentindo-se desconfortável com a superioridade da escrava, a governanta começa a questionar seu papel ali, que devia no seu entender, ser ocupado pela mãe da criança. Esta é, então, a primeira referência que temos da Senhora do Grotão. A de uma mulher insensível e frívola que the havia recomendado o vestido sem qualquer manifestação de tristeza, preocupando-se apenas em detalhar o modelo: "saia redonda, manguinhas de quitute e a

${ }^{136}$ PENNA, Cornélio. A Menina Morta. In: Cornélio Penna Romances Completos. Rio de Janeiro, José Aguilar, 1958, p. 730. 
saia curta". Pensa na sua arrogância e a imagina lendo o livro de capa de couro ou apenas revendo suas joias "realengas", como costumava fazer nos momentos de maior perturbação da casa.

A Senhora, todos diziam ter ela porte de rainha, e a governante verificava todos os dias que a sua figura e seus gestos eram muito mais imperiosos e altivos do que os das louras e adiposas princesas por ela entrevistas em sua cidade.

- Isto tudo é por causa dos escravos, ela está acostumada a viver entre eles... pensava a pobre Sr.. Luísa, quando se sentia esmagada, enterrada bem fundo pelo olhar verdadeiramente imperial da fazendeira, ou quando tremia e se curvava, ao vêla passar com seus passos pequenos e precipitados, sem fazer mover a fímbria de seus vestidos enormes, de cabeça erguida. Nunca olhava onde punha os pés, como se estivesse certa de que o mundo todo devia se aplainar, submisso e cheio de gratidão, à sua passagem, e o frufru de sedas espessas, muito puras, que a anunciava, era o sinal para que todas as portas se abrissem e todos se inclinassem, diante das ordens dadas mediante breves palavras, sibiladas entre os lábios muito finos e pálidos. (...) Tudo na fazenda fazia prever a senhora de rosto redondo, formas opulentas, a voz gritante, sempre boa e familiar, comum naqueles tempos, e, entretanto, quem nela vivia era aquela dama seca e altiva, sem a menor comunhão com os outros moradores... ${ }^{137}$.

Como outros personagens, ela observa com estranheza os hábitos da dona da fazenda. No entanto, só ela como estrangeira e, além disso assalariada, percebe a distorção do comportamento da elite senhorial provocada pela escravidão, de como a dominação direta sobre os homens, a existência legal e legítima do domínio privado de um ser humano sobre outro, imprime nos proprietários este sentimento de superioridade implicado na postura altiva e imperial.

Embora tenha consciência da situação que a cerca, e se ressinta da humilhação que sofre, sua consciência não a impede de agir do mesmo modo em relação à escrava. Ela a trata com o mesmo desprezo com que é tratada pela Senhora, com a mesma altivez que a humilha e a faz tremer e curvar-se.

O leitor é colocado, portanto sem mediações, diante de uma cena dramática cujo espaço também traduz a severidade, o peso e a opressão da estrutura de dominação que o caracteriza:

Estavam na sala de costura da fazenda de altas paredes caiadas onde se encostavam dois armários de jacarandá escuro, bojudos, e cujas portas entre colunas tinham sido escancaradas. Via-se bem o seu interior onde se amontoavam peças de linho, de seda, de merinó e de cassa da Índia, pousadas em prateleiras sucessivas até bem no alto e, lá em cima, as plumas e flores artificiais deixavam ver suas cores delicadas.

${ }^{137}$ Ibidem, pp.731-732. 
Todos os elementos se articulam de modo a introduzir o leitor em um ambiente opressivo. Cabe notar que, além das paredes altas e apenas caiadas, que denotam austeridade, não por acaso é nas prateleiras superiores, dada a sua pouca utilidade, que se guardam os ornamentos de trajes próprios a festas ou outras comemorações.

Retomando a questão colocada acima sobre a suposta neutralidade do narrador, parece-me importante destacar ainda, com a apresentação da governanta, um procedimento característico do seu discurso em grande parte do romance, que é o de parecer colar-se à perspectiva dos personagens, como se apenas reproduzisse seus pensamentos e percepções.

\footnotetext{
A senhora de meia idade a quem chamavam "dona Frau" devia ser alemã pela cor dos olhos e da pele, mas vestia-se tal como as fazendeiras brasileiras o faziam e trazia enfiada nos cabelos certa agulha muito grossa e longa.
}

Embora o sujeito da enunciação seja o narrador, o comentário parece ser mais da escrava do que deste, sobretudo se atentarmos ao modo como qualifica o adorno que segura seu cabelo. Depois de dizer que ela "parecia" alemã, ele afirma que ela já tinha trabalhado em casas nobres no Grão-Ducado de Baden. O autor parece fazer uso da ambiguidade própria do discurso narrativo, projetando ao mesmo tempo a perspectiva do narrador e a do personagem no registro da enunciação, e assim aproximando o leitor do universo do personagem e reforçando o efeito de objetividade que, no entanto, já está dado no uso do discurso indireto. A falta de intervenções ou comentários, assim como o fato de dar andamento à ação menos através de sumários narrativos do que através de cenas, ou o de restringir, com frequência, sua perspectiva à dos personagens, reforçam esta suposta objetividade.

Podemos pensar ainda que a forma como se apresenta a história se assemelha à do teatro. De um lado apresenta-se o teatro do mundo, com máscaras e papéis a representar; de outro, coloca-se o leitor diante de um drama em que todos se debatem uns contra os outros e consigo mesmos. Só conhecemos as atitudes, palavras e pensamentos dos personagens quando estes estão em cena embora, paradoxalmente, estes sejam mediados por um narrador onisciente. Ele parece apenas sentir o que eles sentem e ver o que eles veem, provocando a impressão de que sua voz se confunde com a deles, o que aumenta as 
dificuldades do leitor em compreender esse narrador que parece se ocultar, de certa forma, por trás dos personagens.

Depois de Frau Luísa e da velha mucama, é a vez de José Carapina, um velho carpinteiro que se apresenta através da expressão de sua interioridade.

\begin{abstract}
$\mathrm{Na}$ alma do velho carpinteiro cativo enovelavam-se pequenos e confusos problemas, que se formavam e desapareciam sem que ele pudesse perceber onde estava a verdade e até onde ia a tentação do demônio, pois parecia-lhe grande crime estar a fazer o caixão onde seria aprisionada a Sinhazinha. (...) Nunca sentira tristeza tão grande e tão estranha, nem mesmo quando fora vendido pelos seus antigos senhores, pois não nascera ali, e sim muito abaixo do rio, na humilde "situação" onde os donos morenos e pobres quase se confundiam com os escravos. Viera de lá com a respiração cortada de soluços, e às vezes parecia ter sido essa uma irremediável desgraça sem fim e sem medida que Ihe acontecera, mas o coração lhe doía ao lembrar-se que, no caminho, o tinham assaltado as esperanças de comer bem e tornar-se "negro importante" da fazenda do novo Sinhô muito rico, que ia sempre à Corte e conhecia o Imperador. Nos dias seguintes à sua chegada à fazenda, tivera vontade de fazer como os negros novos, arribados de pouco, que não falavam e comiam terra escondido, no desejo de morrer. Primeiro ficavam com a pele escura e sem brilho, depois quase cinzenta, com laivos amarelos sob os olhos e o pescoço, para depois muito lentamente vir a morte, entre grandes sofrimentos, que os levaria de volta para a Benguela distante, para a Guiné selvagem e livre. ${ }^{138}$
\end{abstract}

A partir da dor pela morte da criança e da angústia de estar construindo um caixão para encerrar o corpo dela, o escravo rememora seu passado e encontra espaço para chorar suas próprias dores, embora pareça não se dar conta disso. Sem qualquer revolta, ainda se sente agradecido e acredita ter sido contemplado pela sorte porque, mesmo sem ter tido mais notícias de sua gente e sabendo nem mesmo poder reconhecer mais os pais, se imagina em melhores condições que eles.

Hoje a mulher que o Senhor Ihe tinha dado, os filhos que tinham nascido, andavam todos de camisa branca e calça de zuarte, e a negra Almerinda tinha coragem de usar colar vermelho sobre o vestido de chita de tundá... Mas, tudo isso, apesar da bondade severa do Sinhô e da caridade distante e rica da Sinhá... ${ }^{139}$

Toda a reflexão de José Carapina, cujo nome vem do seu ofício de carpinteiro, traduz o drama da escravidão, retratada de forma realista. Sabemos que negociados como simples mercadoria, e apartados de suas famílias sem quaisquer direitos, ficavam à mercê do arbítrio dos proprietários, submetidos a um poder irrestrito que estes Ihes impunham, aí incluídos casamentos arranjados segundo as conveniências do senhorio, e até mesmo interferências nas desavenças dos casais, que podiam resultar em punição. Ao lembrar que se envergonha,

\footnotetext{
138 Ibidem, p.734

139 Ibidem, p.735
} 
assim que chega à fazenda, de poder comer o que os antigos senhores só dispunham em dias de festa, e de não ter tido coragem de fazer como muitos recém-chegados que comiam terra escondido, faz referência a uma prática que, entre outras, era utilizada como forma de resistência, e que objetivava a morte como única possibilidade de reencontrar a liberdade. Através das recordações do carpinteiro, temos acesso também às condições precárias a que eram submetidos os escravos nas pequenas propriedades, assim como às compensações imaginárias de se distinguirem em função da posição ocupada pelos senhores. O medo que sente enquanto levado por seus novos proprietários se mistura à esperança "de comer bem e tornar-se "negro importante" da fazenda do novo Sinhô muito rico, que ia sempre à Corte e conhecia o Imperador." 140

A referência à bondade severa do antigo Senhor e a caridade distante e rica da Sinhá, assim como o profundo respeito com o luto, que o leva a amortecer as batidas do martelo de modo a poupar os senhores do barulho, denotam o respeito e a humildade do escravo, cujo comportamento reflete a ideologia dominante: a da autoridade benevolente, a da atitude paternal, severa mas justa, que legitimava a violência e o poder dos proprietários de escravos, e à qual estes deviam corresponder com humildade, obediência e fidelidade ${ }^{141}$.

Bruno, o cocheiro, é apresentado a seguir, ele também em ação, preparando o carro para ir à cidade. Repreendido pelo barulho que faz ao tentar acalmar os cavalos, confere de quem parte a observação antes de acatá-la. Excepcionalmente, em função das circunstâncias, não sem antes mostrar sua contrariedade, admite receber a recomendação de uma mulata moça.

Assim como o velho carpinteiro, também o cocheiro num momento de tristeza legitimada, lembra-se de quando estivera no Rio de Janeiro como pajem do Sinhozinho. É de forma sempre indireta, portanto, que temos acesso aos fragmentos dos acontecimentos passados que vão compondo a história da fazenda e dos moradores. Ele relembra momentos de convívio com a menina quando levava a Senhora até a mata, onde ela ficava "mergulhada em reflexões sem fim" revelando, por exemplo, que a Sinhá não gostava de ver os negros no trabalho, nem de ouvir seu canto, o que o obrigava a desviar dos eitos, ou que, enquanto

\footnotetext{
140 Ibidem, p.734

${ }^{141}$ Emília Viotti da Costa. Da Monarquia à República. p.292.
} 
aguardavam por ela, a menina se divertia batendo nele com uma varinha de bambu, usada normalmente para chicotear os animais, que ele mesmo providenciava para ela. Mais uma vez destaca-se a posição da alemã que desaprova a brincadeira e "trejeitava visagens de repugnância". É interessante observar a diferença do nível de consciência de ambos. Mesmo guardando distância e não querendo se confundir com a escravatura e por isso se calando, Da. Frau mostra desconforto com a pretensa brincadeira que percebe inadequada. $\mathrm{O}$ cocheiro, que se alegra em provocá-la, percebe sua repugnância mas não o motivo, denotando a introjeção da ideologia dominante, julgando que o que a teria contrariado era a aproximação que ele havia estabelecido com a criança e não o fato de estimulá-la a uma prática abjeta.

Mas as brincadeiras e provocações só têm lugar durante a ausência da Senhora, já que ninguém se atreveria a fazer qualquer movimento de interação diante dela.

Como nas mágicas vistas na Corte, tudo cessava em segundos, e quando a figura alta, emergindo do grande balão que parecia caminhar sozinho, soerguido pelas mãos cobertas de rendas, sem tocar no chão, sem despedaçar a cassa que o cobria nas pedras e nos espinhos secos, surgia, tudo se tinha transformado. ${ }^{142}$

A altivez de Dạ. Mariana e sua atitude senhoril são pontuadas pelo escravo, assim como já haviam sido pela governanta e ainda serão pelos outros personagens. É interessante observar que ela é vista pelo cocheiro quase sem materialidade, como um espectro, pois a semelhança das personagens a fantasmas é referida com frequência ao longo do romance. Não são, no entanto, fantasmas que assombram, mas seres de existência fantasmal, que existem como sombras, sem vida própria.

No capítulo subsequente é focalizado novamente o interior da casa, onde duas senhoras lavam o corpo da menina. Se no primeiro capítulo tínhamos a governanta e uma escrava, temos agora duas agregadas da família que, embora compartilhem, a princípio, uma mesma posição não têm qualquer identificação entre si. Durante o ritual, minuciosamente descrito, o narrador já dá indicações do caráter de cada uma das personagens, destacando a mais velha, prima do Comendador, que domina a cena.

\footnotetext{
142 PENNA, Cornélio. A Menina Morta. In: Cornélio Penna Romances Completos. Rio de Janeiro, José Aguilar, 1958, p.739
} 
Era bem velha, e os cabelos brancos prateavam os cachos preguiçosos, que formavam contraste com o seu rosto fino e alongado, de perfil agudo, ainda mais acentuado pela boca rasgada, de lábios sinuosos e rasos. Os olhos à flor da pele, muito negros, examinavam constantemente tudo que se passava diante deles. ${ }^{143}$

Inconformada por não ocupar o lugar da Senhora, refere-se a ela como coração de monstro e a recrimina por sua incapacidade de cuidar da criança: Ainda se vê ser menina destinada a ser mulher robusta, capaz de ter muitos filhos e fundar outra fazenda maior que esta! Não há justiça neste mundo... não... Mas a injustiça a que se refere denota grande inveja da posição ocupada pela senhora, sob a pretensa desculpa de que cumpriria melhor do que ela o papel de mãe e o de esposa, em um momento em que eram comuns os casamentos entre parentes:

Da. Virgínia arrastava as sílabas, de forma chocarreira e misteriosa, quando se referia à origem da Senhora, e acentuava bem as reticências, com afetação, para deixar em suspenso, a fim de que se formassem à vontade toda a sorte de suspeitas em torno dessa gente altiva, intratável e maldizente, que tanto ocupava posições de destaque como surgiam com cara de fome e roupas no fio, sem deixar nunca de exigir respeito e acatamento. Nunca pudera perdoar a alguns deles a indiferença fingida com que a tratavam quando vinham visitar a Sinhá, nivelando-a a essa "alemã" invejosa, ignorante e bajuladora, que agora servia de criada grave ou governante, sabia-se lá! Nunca pudera saber ao certo qual era a situação social dessa família, tão diferente da do Comendador, unida e igual, apesar de algumas ruínas e desastres, porém honrosos e discretos.

Controladora, ressentida e maledicente, a personagem incorpora a ideologia patriarcal e reafirma todos os seus valores e preconceitos, agindo com superioridade em relação aos outros personagens. Inconformada de ter perdido prestígio social e financeiro, preocupa-se em destacar-se das outras agregadas e não admite nem mesmo ser chamada prima pela outra, baseando-se em critérios de distinção que visam a atenuar sua posição de dependente. O comportamento de D. Virgínia ilustra a falta de solidariedade que marca sua atuação, competindo sempre por uma superioridade, ainda que momentânea, com relação aos outros. Trata-se das compensações imaginárias de que fala Roberto Schwarz sobre estas figuras que Machado era mestre em explorar ${ }^{144}$.

Já a mais jovem figura como mera coadjuvante, e é apresentada como parente pobre e ainda por cima da Senhora. Filha de ex-criadores de gado, empobrecidos com a chegada do café na região, havia sido "recolhida" no Grotão depois da morte de seus pais.

\footnotetext{
${ }^{143}$ Ibidem, p.741.

${ }^{144}$ Roberto Schwarz. Um mestre na periferia do capitalismo. São Paulo: Duas Cidades, Ed.34, 2000. p. 30-31 e 65.
} 
Seus olhos fundos sob as sobrancelhas negras, única referência ao seu aspecto físico, já indicam seu pendor romântico, que se explicitará no decorrer da narrativa.

Em meio à apresentação do ambiente e da estrutura que vai ter lugar no romance, um aspecto que chama a atenção nesses primeiros capítulos são as indicações de certo misticismo, reforçado pelas comparações feitas com imagens religiosas de forma aparentemente gratuita, e que parecem remeter à indefinição entre o discurso do narrador e dos personagens, referido anteriormente. Já no primeiro parágrafo do romance, a escrava segurando o vestido da menina ergue as mãos "no gesto das Verônicas das procissões", assim como se benze para afastar qualquer possível influência maléfica da governanta. ${ }^{145}$ Antes de terminarem o vestido, ele deveria ser experimentado no corpo da menina, pois com ele ela "subiria ao céu onde iria comparecer diante de Deus, e Êle tudo vê..."146 O carpinteiro, ao rememorar fatos e sentimentos antigos teme estar sendo tentado pelo demônio e, depois de terminar o caixão coloca-o "sobre os ombros, como se fosse uma cruz, e (atravessa) o grande quadrado, muito curvo, penosamente, esmagado pelo seu peso enorme, acima de suas forças..." ${ }^{147}$.

É a partir da descrição da entrada da fazenda que o narrador põe em cena o patriarca e dá início à narrativa:

\begin{abstract}
Assim, parecia grande desenho em sombra chinesa, adoçada pela penumbra, que os animasse de repente, a figura do cavaleiro que a percorria, levado pelo trote muito ritmado do cavalo meio-sangue árabe, vindo das coudelarias da Corte, em cuja cor castanha brilhavam reflexos de ouro fulvo, lembrança persistente dos animais de sangue real de sua ascendência. Sacudido pelo balanço regular da montada, o Senhor deixava-se conduzir e se não fosse o movimento que lhe imprimia essa marcha, dirse-ia uma estátua, tal como as das procissões das cidades velhas, tamanha era a imobilidade de seus traços fisionômicos, de seus braços e de suas pernas, mantida sempre na posição clássica do ginete, sem demonstrar vida por qualquer desvio ou sinal de cansaço e impaciência.
\end{abstract}

\footnotetext{
${ }^{145}$ É interessante observar que o episódio em que Verônica enxuga o rosto de Cristo a caminho da crucificação, com um pano em que fica estampado o seu rosto, e que constitui objeto de culto nas procissões que celebram a Paixão de Cristo, não figura nos Evangelhos, mas em textos posteriores e apócrifos. Além disso, Verônica significa etimologicamente "verdadeiro ícone", o que remete a representação, e estabelece com o objeto representado uma relação de semelhança que poderia, nesse sentido, ser pensada como uma analogia que o autor estabelece com a Literatura, tendo em vista que esta cria um mundo que se coloca no lugar da realidade, tem nela seu referente, sem com ela se confundir.

${ }^{146}$ PENNA, Cornélio. A Menina Morta. In: Cornélio Penna Romances Completos. Rio de Janeiro, José Aguilar, 1958, p.731.

${ }^{147}$ Ibidem, p.736.
} 
Caminhava... caminhava... e os raios oblíquos de luz, ora dourados, ora vermelhos, ora violeta, o iluminavam alternadamente e coloriam o seu longo jaquetão, cujas abas cobriam a calça alvíssima, escondida em parte pelas botas de couro envernizado, em vez de lhe darem vida, tornavam ainda mais fantástica a indiferença por tudo que desfilava rapidamente ao seu lado, pois deixava para trás sem olhar, sem que sua cabeça erguida duramente se desviasse uma linha, os mais belos pontos de vista, alguns deles já fixados em tela pela fazendeira, discípula de artistas de fama, muitos deles vindos à fazenda para retratar as pessoas da família. ${ }^{148}$

A imagem da aproximação do fazendeiro é extremamente pictórica, e se compõe num jogo de cores, luz e sombras, através da qual o narrador ao mesmo tempo descreve a ronda cotidiana do Comendador pela fazenda e introduz elementos que permitem que o leitor componha sua caracterização. A figura impassível, indiferente e majestosa do cavaleiro de contornos não nítidos, parece revelar antes a postura própria ao papel que representa do que sobre aquele que o desempenha. Através, portanto, da descrição ele introduz os elementos da narração, projetando aspectos que ultrapassam a visualidade do quadro: visto de longe, inabalável e incomunicável, reafirma sua autoridade olhando tudo e todos, sem responder nem mesmo com um aceno aos que se curvam diante dele, como um monarca que não se digna a manifestar sua satisfação ou desagrado. A luz, que incide sobre pontos específicos, amplifica a dramaticidade da cena e se ajusta à figura que se mostra e se oculta.

Ao mesmo tempo que a figura do Comendador se mistura à natureza, com ela faz um contraponto. Isolado na sua posição de mando, a imobilidade dos seus traços transmite austeridade e imponência, e a solenidade com que se impõe faz com que seja comparado às estátuas das procissões. Sua imagem, portanto, o desumaniza e impregna-se de um poder simbólico que o transfigura em essência de poder a ser respeitado e, talvez mais do que isso, reverenciado. Dele emana toda a força, que se concentra nas suas mãos. Como patriarca, era dono de terras, dono dos homens, donos das mulheres ${ }^{149}$. Até 0 animal percebe sua potência, o que de certa forma naturaliza o seu mando:

Era de novo o pulso forte que o guiava, e sentia outra vez sobre os seus flancos as coxas possantes que sabiam orientar por meio de simples pressão, fazendo com que ele se tornasse o prolongamento de sua vontade, formando um só todo com o cavaleiro.

Quando reproduz o efeito da postura do cavaleiro no animal, o narrador não apenas generaliza o sentimento deste a todos os moradores, como reafirma uma atitude viril e de

\footnotetext{
148 Ibidem, p.745

${ }^{149}$ Gilberto Freyre. Casa-grande e senzala. 2000... p..50
} 
poder patriarcal. Esta representação é ainda reforçada por posterior descrição, que retoma os termos da apresentação inicial:

\begin{abstract}
O sol batia em cheio na sua figura rude e ele parecia a estátua de proa da grande nave constituída pela fazenda enorme, pesadamente espalhada, com os mastros erguidos das palmeiras a agitar suas flâmulas aos ventos. Aquela presença masculina, poderosa, fonte e origem em potência de muitas vidas, que viriam ao mundo ricas de seiva e se prolongariam e multiplicariam pelos séculos, era bem a do patriarca dominador de todo aquele grupo de homens e mulheres, era o tronco da árvore sem medida cujos galhos se reproduziam sem cessar ${ }^{150}$.
\end{abstract}

A imagem da estátua é retomada, reforçando a sua impassibilidade de um lado, ou seja, alguém imperturbável, que não deixa transparecer qualquer emoção ou sentimento e, por outro, uma representação, sem vida.

É, portanto, ao se aproximar do pátio da casa-grande, elemento representativo de todo um sistema econômico, social e político ${ }^{151}$, que há uma mudança na atitude do Comendador. Ele não mais se deixa levar pelo cavalo enquanto percorre os campos, mas assume seu domínio sobre o animal com a postura que o caracteriza, vigoroso e grave, cheio de vida e seguro de sua vontade.

Imediatamente depois de descrever essa figura imponente e imperturbável, comparada a um desenho em sombra, o narrador reafirma o "paternalismo" do fazendeiro, que manda vir "tonéis cheios de refresco feito com a fruta da época", e afirma:

Era a atenção solícita do Senhor, a presença paternal que os mantinha sempre em saúde, a fim de ser conseguido o rude vigor que se esperava deles. Mas a terra respondia generosamente aos seus esforços, e abria-se sempre em riquezas inesgotáveis, na fartura que os irmanava no total sentimento de pujança. ${ }^{152}$

Novamente se coloca a questão de quem fala. De que perspectiva fala o narrador? Quem o vê como presença paternal, os escravos? Parece ambígua sua posição. É à falta de consciência dos escravos que o autor está se referindo? Ao afirmar que a fartura irmana dominados e dominantes num sentimento de pujança ele estaria traduzindo o sentimento

\footnotetext{
150 PENNA, Cornélio. A Menina Morta. In: Cornélio Penna Romances Completos. Rio de Janeiro, José Aguilar, 1958, p.1058.

${ }^{151}$ Gilberto Freyre. Idem p.49

152 PENNA, Cornélio. A Menina Morta. In: Cornélio Penna Romances Completos. Rio de Janeiro, José Aguilar, 1958, p. 746.
} 
do patriarca ou dos escravos que, imbuídos da ideologia patriarcal, e mesmo sem usufruírem dessa pujança, se sentiriam gratificados pela riqueza que criam? Ou ele está apenas reafirmando o valor da terra como fonte de riqueza e poder? Ou ainda, estaria ele usando de ironia?

Mas o fazendeiro não é apenas o senhor de terras, o senhor feudal, conforme formulado por uma das parentas ao manifestar a insegurança e a vulnerabilidade implicada na posição de agregada, e que remete às interpretações feudalizantes equivocadas de nossa formação.

A fazenda era enorme e rústico palácio, fortaleza sertaneja de senhor feudal sulamericano, e tudo ali era grande e austero, de luxo sóbrio e magnífico, mas era preciso viver naquelas salas amplas, de tetos muito altos e mobiliadas com móveis que pareciam destinados a criaturas gigantescas, sem contar com coisa alguma de certo nem no presente nem no futuro ${ }^{153}$.

É também o capitalista associado a comissários e agentes financeiros da cidade que defende seu capital de forma objetiva e que tem em vista o mercado internacional. Se ele alimenta os escravos é para manter uma condição mínima para que estes suportem o trabalho e sejam produtivos, além de garantir o investimento que representam.

Não por acaso, a observação parte de Celestina, uma das parentas, enquanto indaga sobre os limites da sua liberdade naquele mundo sem direitos. O seu mundo é o mundo do favor, do arbítrio, do mando pessoal direto, do trabalho escravo. É, pois, nas relações que se estabelecem entre proprietários e dependentes que se caracteriza este mundo não burguês, paradoxal a um mundo inserido na lógica do capital.

Finalmente o Comendador adentra a sala em que está sendo velada a filha, em completo desacordo com a atmosfera de consternação que o momento impunha. Temos, neste momento, a única revelação de sua interioridade:

Deu alguns passos, e o ruído martelado de suas botas, o tilintar das esporas, pareceram-lhe sacrílegos. Sentia, confusamente, ter trazido lá de fora a lama e a podridão dos brejos e das terras frementes de seiva presas aos seus sapatos e reconheceu não serem suas mãos dignas de tocarem naquela figurinha de cera.

Nas pontas dos pés, com o chapéu seguro junto ao peito, repetiu maquinalmente o mesmo sinal de respeito de seus escravos diante das imagens do oratório, que passavam à frente dele medrosos, fazendo-se pequenos, para que Deus não visse

153 Ibidem, p.856 
toda a extensão de sua miséria, tão grande que a julgavam indigna de seus divinos olhos...

Foi então para junto da Senhora, mas já sabia que não encontraria ao seu lado apoio para o seu coração vacilante. Era sozinho que devia atravessar as longas horas que o esperavam...154

A objetividade, a impessoalidade e o pragmatismo com que age o impedem de mostrar seu abatimento. Mesmo num momento de dor não deixa transparecer seus sentimentos, em nome do papel que representa e da autoridade que não quer ver questionada.

Enquanto temos acesso à interioridade dos agregados e de alguns dos escravos, assim como de Carlota, a filha do casal que ocupa um espaço intermediário específico e em quem parece se plasmar o olhar do narrador a partir de um determinado momento, sabemos muito pouco dos pensamentos da Senhora e nada dos do Comendador. Além da referência acima, temos conhecimento apenas do constrangimento do patriarca diante da porta do quarto quando, ao reparar na maçaneta se detém impactado pelo simbolismo da decoração piegas que estampa a figura de Cupido, imaginando a possibilidade de a senhora perceber sua hesitação. Figura que se impõe pela posição que ocupa e referido sempre pelo título que ostenta, se deixa conhecer apenas pelo olhar dos outros personagens e do narrador, que não adentra sua interioridade.

Tanto ele quanto a mulher recusam-se a receber as condolências dos parentes e conhecidos que haviam ido prestar sua solidariedade, evitando, assim, qualquer socialização que dissolvesse, mesmo que temporariamente, suas diferenças em relação àqueles. Nem a morte da filha perturba a rotina de vistoriar os trabalhos do campo ou a preocupação da mãe com o modelo do vestido que a menina deve usar e com a arrumação da casa que, como pontuado pelo narrador, pareciam relativos a alguma comemoração de pompa.

Os primeiros capítulos, portanto, indicam não só que a construção da imagem social é feita por dentro, e pela voz dos que são submetidos à opressão, como também parecem condensar a atmosfera da narrativa e introduzir os elementos que nela predominam: uma elite com pretensões nobiliárquicas em um ambiente dominado pela hierarquia, protocolos, interdito, enigmas, medo, angústia e misticismo.

154 Ibidem, p.748 


\section{Um olhar sobre a representação feminina}

Se o romance já foi considerado por Augusto Frederico Schmidt um dos grandes relatos que se fez sobre a escravidão ${ }^{155}$, podemos pensar que o mesmo se dá em relação à vida dos dependentes que, junto com o núcleo familiar e, todos sob a autoridade do patriarca, compunham as famílias de então, conforme analisado por Simone R. Rufinoni ${ }^{156}$.

Sem contrariar as referidas posições, uma vez que o romance faz um relato contundente da escravidão e das relações sociais que se engendram a partir dela, chama atenção o fato dele se estruturar a partir das personagens femininas.

Tendo em vista que o interior da casa é a perspectiva sob a qual se constrói a narrativa, e sendo este o lugar em que a mulher não escrava experimenta a principal função social que lhe cabe no sistema patriarcal, elas não apenas predominam na cena juntamente com as escravas 'de dentro', como é pela voz ou pelos pensamentos dessas mulheres que se apresenta uma pluralidade de pontos de vista que levam o leitor a perceber, por diferentes ângulos, as questões e os sentimentos que ressoam nos personagens. Através dos seus impasses íntimos, única forma possível de representação naquele universo em que domina o interdito, o que se evidencia são os conflitos, sejam sociais sejam da posição subordinada da mulher na ordem patriarcal.

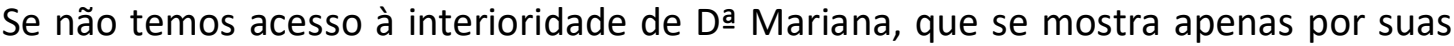
atitudes, pelo olhar que os outros moradores têm dela e por referências sutis entremeadas no texto, adentramos a interioridade das agregadas e da filha do fazendeiro. Temos acesso ainda aos pensamentos e percepções da governanta, que se destaca do grupo por ter uma relação de trabalho clara e remunerada, opondo-se ao que acontece com o administrador, também livre, assalariado e estrangeiro, sobre quem não temos qualquer informação. Quanto às escravas que participam da intimidade da família, há um ou outro pensamento

${ }^{155}$ SCHMIDT, Augusto Frederico. “Nota preliminar". In: A menina morta. In: Romances Completos. Rio de Janeiro: Nova Aguilar, 1958, p.724.

156 Este aspecto foi introduzido e amplamente discutido por Simone Rossinetti Rufinoni em Favor e Melancolia - Uma leitura de A menina morta, de Cornelio Penna. Tese de Doutorado. São Paulo: Faculdade de Filosofia, Letras e Ciências Humanas, Universidade de São Paulo, 2005. 
traduzido por suas falas ou pelas do narrador, mas muito acanhadas em função do interdito que domina sua situação.

Ao colocar a mulher no centro, privilegiando sua representação, e articulando-a com as questões de raça e posição social, o autor mapeia na década de 50 o que vai ser uma questão do discurso histórico a partir dos anos 70, quando a história das mulheres surge como objeto de análise, e a introdução dos estudos de gênero ampliam as críticas feministas. ${ }^{157}$

Muito embora não se esteja considerando neste estudo a mulher como categoria de análise, como grupo reunido sob uma única identidade, ela se configura como diferença em relação ao homem e, portanto, como Outro. Relacionado à questão do poder, o ponto de vista que identifica o feminino como discurso do Outro já foi apontado por Luís Bueno, cujos estudos analisam a importância da figuração do Outro realizada pelo romance de 30, e como ela assumiu diferentes soluções ideológicas e estéticas. ${ }^{158}$

O romance caracteriza a sociedade escravista em que, sem quaisquer direitos políticos, econômicos e sociais, as mulheres ficavam submetidas ao patriarca a quem deviam obediência. A predominância desse modelo nos grandes latifúndios exportadores não significa, no entanto, que a experiência da mulher não tenha apresentado variações, numa sociedade tão diversa e desigual, ou que já não ocorressem mudanças na vida dessas mulheres na segunda metade do século XIX.

Depois dos primeiros estudos e teorias formuladas no início do século XX acerca da organização e estrutura da família brasileira segundo o modelo patriarcal, há uma primeira revisão nas análises das décadas de 50 e 60 que inclui não apenas as diferenças regionais e

\footnotetext{
${ }^{157}$ SOHIET, Rachel e PEDRO, Joana Maria. "A emergência da pesquisa da História das Mulheres e das Relações de Gênero". In: Revista Brasileira de História [online]. Dez.2007, vol.27, n. 54.p;281-300. Disponível em <http://www.scielo.br/scielo.php?pid=S0102-01882007000200015\&script=sci_abstract\&tlng=pt $\geq$ Acesso: 22/05/2017.

${ }^{158}$ Luís Bueno centra-se na análise da figuração do outro feita pelo romance de 30, e elege Cornélio Penna como um dos quatro autores a quem dedica uma análise mais pormenorizada, justificando-a não apenas por ele ter sintetizado na sua obra os grandes problemas do seu tempo, como por ter sido um dos autores cuja permanência se sente na ficção brasileira posterior e, sobretudo, por ter sugerido "o fracasso humano - e religioso - da opção pela submissão do outro". Cf. BUENO, Luís. Uma história do romance de 30. São Paulo: Edusp; Campinas: Editora Unicamp, 2006, p.548.
} 
de classes sociais, como o papel das mulheres na formação desses núcleos familiares e sua atuação no conjunto da sociedade ${ }^{159}$.

Mas é nos anos 70 que a família volta a ser objeto de análise. Os estudos, baseados agora em fontes documentais históricas, indicaram como as transformações ocorridas ao longo do século XIX implicaram grande diversidade de modelos familiares e de um sistema patriarcal modificado ${ }^{160}$, inclusive tendo muitas vezes a mulher no comando dos domicílios, principalmente nas áreas urbanas a partir do final do período colonial. Daí a crítica à generalização da família patriarcal como hegemônica, em que outras formas de organização familiar apareceriam como extensões desse núcleo. Contrariando a visão histórica dos estudos de Gilberto Freyre e do ensaio de 1951 de Antonio Candido sobre a família brasileira $^{161}$, e a partir de um levantamento da ocupação do espaço social e da distribuição do trabalho em diferentes regiões, Mariza Corrêa fala do risco de uma "homogeneização histórica" em

que uma situação bem localizada no tempo e no espaço - a economia açucareira pernambucana dos séculos XVI e XVII ou a plantação de café dos séculos XVIII e XIX transforma-se em matriz, em denominador comum, da sociedade colonial inteira, do século $X V I$ ao século $X I X^{162}$.

No entanto, assumir a diversidade nas formas de organização familiar relativizando a imagem dominante da família patriarcal no processo de formação da sociedade brasileira não implica desconsiderar sua existência na constituição das unidades domésticas das elites, sobretudo nas grandes propriedades latifundiárias em que ela persiste até fins do século XIX, nem no padrão cultural a que deram origem.

\footnotetext{
${ }^{159}$ Eni de Mesquita Samara cita como obras fundadoras na formulação do modelo patriarcal a obra de Gilberto Freyre, assim como os trabalhos de Oliveira Vianna Populações Meridionais do Brasil, Luís de Aguiar Costa Pinto Lutas de famílias no Brasil: era colonial e Alcântara Machado com Vida e morte do bandeirante, assim como o ensaio de Antonio Candido de 1951 marcando esse primeiro momento de revisão. Cf. SAMARA, Eni de Mesquita. "A família no Brasil: História e Historiografia no século XX". In: Francisco Chacón Jiménez... et al. Sin distancias: Família e tendencias historiográficas em el siglo XX. Universidad de Murcia - Universidad Externado de Colombia, 2002, pp.99-115.

${ }^{160}$ Essa análise segue de perto o ensaio mencionado na nota acima.

${ }^{161}$ CANDIDO, Antonio. "The Brazilian Family" (Extraído de Smith, T. L. e Marchant, A. (Eds). Brazil, portrait of a continent. N. Y.: The Dryden Press, 1951)
}

162 Mariza Corrêa ... et al. "Repensando a família patriarcal brasileira”. In: Colcha de Retalhos:

Estudos sobre a família no Brasil. Campinas: Editora da Unicamp, 1993, p.19. 
Enquanto representação de um grupo social hierarquizado, essa estrutura patriarcal é bem caracterizada no romance, evidenciando a dominação do homem, a submissão da mulher e o casamento entre parentes como forma de fortalecer e consolidar laços de solidariedade, preservando as fortunas e garantindo a linhagem dentro do grupo familiar. Geralmente acertado pelos pais, o casamento representava o destino das mulheres brancas, cuja honra era definida pela virgindade quando jovem, e pela lealdade ao marido quando casada.

Como dito anteriormente, a diferença entre a vida das mulheres das diferentes camadas sociais não se limitava às condições materiais de que dispunham. Não apenas o comportamento que se esperava delas, como suas preocupações, em muito se distinguiam ${ }^{163}$. A imagem da vocação feminina ao papel de esposa e de mãe, por exemplo, só cabia às mulheres brancas e da elite, uma vez que as escravas, ou mesmo mulheres livres e pobres, participavam igualmente dos trabalhos pesados desempenhados pelos homens. Do ponto de vista da moralidade e do casamento, enquanto para as "mulheres-esposas" impunham-se valores como pureza, comportamento submisso e adequado ao exercício das funções no lar, para as escravas a possibilidade mesma de constituir família dependia do arbítrio senhorial, que lhes concedia ou não o privilégio, além de serem objeto de abuso por parte dos brancos. Com uma moral arraigada, as mulheres brancas e pobres reproduziam por sua vez, com rigidez, o padrão estabelecido para as mulheres da elite em quem se espelhavam como reproduções humildes, e cujas uniões muitas vezes eram difíceis em função de não disporem de dotes.

Desse modo, e oprimidas pelo poder patriarcal, as mulheres não se apresentam como um grupo homogêneo, e menos ainda como força que se opõe, necessariamente, a ele. Algumas reproduzem a autoridade patriarcal, como é o caso de Da Virgínia, enquanto outras têm como traço marcante o desejo de emancipação, como Dạ Mariana e Carlota, o que não lhes retira o comportamento característico de classe. A identidade comum que há entre todas me parece ser a falta de autonomia e a opressão a que estão submetidas,

163 Cf. COSTA, Emília Viotti da. Da Monarquia à Repúbilca: momentos decisivos. 8a ed.rev. e ampliada, São Paulo: UNESP, 2007, p.515. 
fazendo com que compartilhassem um sentimento de aprisionamento e coisificação, que o romance procura traduzir.

Assim é que Carlota se equipara à escravatura quando passa a perceber que, ainda que futura herdeira, ela é apenas uma protagonista cujo papel está pré-definido: "Ihe parecia ser também escrava cuja venda estava em negócio, mediante condições impossíveis de serem imaginadas...". A imagem é retomada muitos capítulos adiante, quando ao ouvir de passagem um comentário sobre seu casamento feito por D. Virgínia,

Teve a sensação de receber rápido látego nas costas. Curvou-se toda dobrada por aquele choque, aquelas palavras que lhe traziam à lembrança, bruscamente, estar toda a sua vida em jogo, e eram aqueles dias decisivos, os agora vividos, prontos a fazerem dela outra pessoa ${ }^{164}$.

Sentir-se uma mercadoria em troca nesse acordo, faz com que compare as palavras às chibatadas levadas pelos escravos que, como mercadorias, e cuja propriedade se definia nos termos mesmo da lei, estavam completamente vulneráveis ao arbítrio do senhor. Firmado o acordo, de propriedade do pai passaria a propriedade do futuro marido.

No mesmo sentido, sem qualquer autonomia para interferir no próprio destino, sente-se ameaçada de perder sua posição caso se contrapusesse ao pai e, identifica-se com a situação dos agregados:

Esquecera por momentos as dúvidas de sempre, a desconfiança de tudo e de todos que a tinham feito chegar à sua própria fazenda semelhante a uma fugitiva, alguém escapada de seus perseguidores, e se refugiasse em alguma cova cheia de bichos rampantes e traiçoeiros, sem saber para onde ir, se a expulsassem dali. Entretanto dentro em pouco a retomaram as mesmas preocupações, a curiosidade dolorosa sentida de saber qual a desgraça à sua espera, à espreita ali, presente em toda a casa e oculta apenas pela vontade de todos que a cercavam. ${ }^{165}$

Antonio Candido, no ensaio acima referido, dedica especial atenção à situação das mulheres. Desmistifica a falta de iniciativa, capacidade de mando e mesmo a passividade atribuídas a elas, e aponta que muitas vezes "auxiliares" diretas dos maridos na manutenção do seu lugar social, chegavam a assumir uma postura tão "patriarcal" quanto a deles.

\footnotetext{
164 PENNA, Cornélio. A menina morta. In: Romances Completos. Rio de Janeiro: Nova Aguilar, 1958, p.1124.

165 Ibidem, p.1024.
} 
É o que vemos na fazenda vizinha em que a prima do Comendador, como outras mulheres na ausência dos maridos, comanda seus negócios e defende seus interesses, com características geralmente associadas aos homens. "Talvez seja possível afirmar ainda que o regime patriarcal criou, no Brasil, condições para o exercício de aspectos viris da personalidade feminina que favoreceram o desenvolvimento de acentuadas características de mando e iniciativa da mulher"166, afirma o crítico.

Altiva e prepotente, a Condessa ampara sua autoridade na figura terrível do marido que substitui com um vigor viril, levando inclusive um relógio preso à cintura, como hábito dos homens de então. E frente ao Comendador, "Eram mais dois adversários a medirem suas forças diante de atento auditório, do que dois pais a decidirem o futuro de seus filhos"167, diz o narrador quando ela vai oficializar o pedido de casamento. A ela se contrapõe a figura desfibrada do filho, completamente submetido às determinações da mãe, com quase nenhuma voz e cuja única iniciativa é a atitude violenta e despropositada ao chicotear o escravo que deixa cair um pacote das mãos.

Sendo a construção do texto guiada pelo olhar, é no contato dos personagens com os outros habitantes da casa que se revelam a interdição e a violência impostas pelo patriarcalismo. Há uma tensão que só se extravasa de modo insidioso, em função da contenção sob a qual vivem. O trato entre os moradores e os senhores, e mesmo o que se estabelece entre eles, é sempre desdenhoso e cheio de repreensão.

A comunicação, reduzida sempre ao mínimo, se dá por olhares, gestos ou por palavras secas e breves. Há uma medida exata para tudo: para o quê falar e quanto falar, e não são poucas as vezes em que os personagens se censuram por perceberem ter ultrapassado este limite. Todos se escondem para não deixar transparecer seus sentimentos, dominados pelo medo e pela estranheza. Os escravos com medo de punições, os dependentes receosos de perderem seu "acolhimento" conscientes da vulnerabilidade de sua posição, e Carlota, por respeito e submissão ao pai.

\footnotetext{
${ }^{166}$ CANDIDO, Antonio. “The Brazilian Family" (Extraído de Smith, T. L. e Marchant, A. (Eds). Brazil, portrait of a continent. N. Y.: The Dryden Press, 1951)

167 PENNA, Cornélio. A menina morta. In: Romances Completos. Rio de Janeiro: Nova Aguilar, 1958, p.1093.
} 
A única que se contrapõe à ordem estabelecida é D. Mariana, que não apenas se recusa a desempenhar um papel de coadjuvante do marido participando da vida da fazenda, conduzindo as tarefas da casa ou tomando conta dos filhos, como se opõe a seu projeto. Seja pelo silêncio que impõe, seja pelos ecos das discussões do casal a que temos acesso, ou ainda pelos momentos de enfrentamento direto com o marido, como quando da vinda do padre a quem ela recomenda seja dada a bênção do corpo de Florêncio, indicando a farsa do suicídio do escravo. Tais contrariedades, no entanto, em desacordo com seu papel social e com a autoridade suprema do patriarca, acabam por lhe custar o afastamento da fazenda e sua sanidade. Importante ressaltar que a censura e a coerção a que ela está submetida não são apenas simbólicas, mas se traduzem em uma censura real, como no caso das correspondências recebidas e encaminhadas.

O romance representa ainda, e em acordo com o modo de vida e o cotidiano de uma família rural patriarcal, a impossibilidade de constituição do sujeito em uma sociedade que se estrutura com base no mando social direto, ou seja, sem a mediação da lei ou de contratos entre as partes, problematizando uma questão que é de fundo histórico. As relações de pertencimento, assim como as fundadas em vínculos de obrigação, ou seja, baseadas em favores e não em direitos, constituem um aspecto importante na nossa formação social e estão bem representadas na trama.

De um lado estão os escravos, que não têm como se constituir em sujeito já que não apenas são vistos e tratados como objeto, mas considerados como tal nos termos mesmo da lei. São coisa, mercadoria com valor de uso e de troca, destituídos de qualquer direito ou autonomia, e assim não se configuram como Outro. Por sua vez, os homens livres e pobres que vivem de favor, presos por relações de reconhecimento e de fidelidade, e que tampouco têm existência autônoma. Excluídos do sistema de produção limitam-se a figurar como extensão dos proprietários e de seu domínio. Aderem à ideologia da classe dominante, e têm uma percepção limitada da realidade social, moldada pelo desejo de identificação com 
os proprietários ${ }^{168}$. Qualquer movimento lhes parece ameaçador, pois pode colocar em risco sua posição de protegido.

A anulação da vontade individual como traço da posição de dependente, uma autonegação - se é que se poderia definir desse modo - revela-se no comportamento dos personagens, incapazes de tomar decisões autônomas, sempre com medo de contrariar o que se espera deles. Os conflitos recalcados e, portanto, não superados se manifestam na forma como reproduzem o tratamento que recebem. A submissão vivida como sujeição voluntária à autoridade daquele que os acolhe elimina sua possibilidade de autonomia.

O romance evidencia também questões complicadas do lado dos proprietários, cujo processo de individuação é bastante problemático. Ao anular o outro, eles não reconhecem limites, o que cria uma autoimagem de prepotência que legitima sua arbitrariedade.

A fazenda, que a princípio poderia pressupor relações de certa intimidade, até pelo isolamento em que vivem os moradores, é palco do mal-estar e mesmo do estranhamento entre os personagens. Eles fecham-se em seus quartos, único espaço de privacidade, e a sala figura como palco de desencontros e contrariedades.

Cabe observar com relação ao isolamento da fazenda recorrentemente aludido, que o pequeno núcleo urbano, a vila de Porto Novo, fica perto o suficiente para que possa ser alcançado a pé. Salvo algumas poucas visitas ao túmulo da menina, este só figura como ponto de passagem para os que estão a caminho da Corte. O próprio nome da fazenda remete a lugar distante e isolado, pois um dos sentidos da palavra Grotão é justamente o de "lugar, região longínqua, geralmente o interior, em relação aos centros urbanos", podendo significar também uma grande grota, "cavidade na encosta de serra ou de morro provocada por água das chuvas", ou ainda "vale profundo ou plano inclinado entre duas montanhas". ${ }^{169}$ A denominação da fazenda, portanto, ecoa o sentido do termo para além da localização geográfica. Como uma fissura do terreno, sugere uma situação de isolamento em que vivem seus habitantes, sobretudo as mulheres confinadas no ambiente doméstico.

\footnotetext{
${ }^{168}$ Este aspecto também foi amplamente discutido na Tese de Doutoramento de Simone Rossinetti Rufinoni. Cf. Favor e Melancolia - Uma leitura de A menina morta, de Cornélio Penna. Tese de Doutorado. São Paulo: Faculdade de Filosofia, Letras e Ciências Humanas, Universidade de São Paulo, 2005.

${ }^{169}$ Cf. Dicionário Houaiss da língua portuguesa.1ạ.reimpressão. Rio de Janeiro: Objetiva, 2004.
} 
Em uma versão preliminar do romance que se encontra nos arquivos literários da Fundação Casa de Rui Barbosa, o nome da fazenda figura como "Fazenda do Cortiço", em uma referência direta à fazenda da família materna do autor. Conforme entrevista concedida a Ledo Ivo, não só é a partir das histórias contadas por sua mãe e tias que tira elementos para a obra, como foi nessa mesma fazenda, situada em Porto Novo, que teria falecido em 1852 uma tia sua, retratada na pintura que lhe serve de inspiração. ${ }^{170} \mathrm{O}$ autor muda o nome da fazenda, mas toma seu significado primeiro ${ }^{171}$ de "colmeia" para referir-se à propriedade, indicando que mantém seu sentido simbólico, e refletindo a rígida hierarquia social, ainda que em uma chave irônica. Assim é quando Da. Mariana seguida pelas outras senhoras dirige-se para o alpendre, lugar aludido pelo narrador como "dos mais frescos da grande colmeia rural"172. Ou quando ele justifica a falta de iniciativa de Frau Luísa que, "sendo estrangeira, ainda não se adaptara, não compreendera o mecanismo da grande colmeia que era a fazenda com a sua numerosa escravatura ${ }^{173}$.

Como as relações entre os habitantes não se estruturam sobre afetos ou sentimentos de identidade, as relações de dominação se evidenciam e se sobrepõem no contato entre eles. Todos observam, vigiam, censuram e são observados, vigiados e censurados pelos outros. A censura é tanto externa quanto interna, pois enquanto a violência pressupõe a submissão, a vulnerabilidade do favor faz com que se internalizem os valores de dependência.

Em meio à indiferenciação em que vivem, buscam reconhecimento e distinção, procurando afirmar-se como indivíduo. Dentro de cada grupo social, o drama de cada um é, no fundo, o drama de todos, uma vez que a experiência social os torna semelhantes. No entanto, esta experiência não é percebida como comum, sobretudo no caso dos dependentes, que se voltam uns contra os outros pela impossibilidade de se voltarem contra

170 Cf. IVO, Ledo. "A Vida Misteriosa do Romancista Cornélio Penna". In: Cornélio Penna: Romances Completos. Rio de Janeiro: Nova Aguilar, 1958, p.LXV

${ }^{171}$ O primeiro significado que consta do verbete de "cortiço" é: "peça feita de cortiça ou de qualquer outra casca de árvore, para alojar colônias de abelhas; colmeia". Cf. Dicionário Houaiss da língua portuguesa.1a..reimpressão. Rio de Janeiro: Objetiva, 2004.

172 PENNA, Cornélio. A menina morta. In: Romances Completos. Rio de Janeiro: Nova Aguilar, 1958, p. 944.

173 Ibidem, p.1193. 
os senhores, para não ameaçar sua condição, e mesmo para não se reconhecerem na condição do outro que sabem ser igual à sua. Sem qualquer possibilidade de emancipação, ninguém julga partilhar de uma mesma posição, reforçando ainda mais a hierarquia das relações e o mal-estar do ambiente.

Edu Otsuka, em trabalho realizado sobre Memórias de um Sargento de Milícias, analisa como estas compensações imaginárias acompanham as rixas por parte dos personagens livres e pobres que visam, através delas, a obter um sentimento de superioridade e certo prestígio em relação aos demais, e assinala ainda como "a própria noção de igualdade parece não ter pregnância no universo dos homens livres figurado nas Memórias"174. Podemos observar o mesmo fenômeno entre as personagens de A menina morta.

As parentas devem a situação de dependência à sua decadência social e econômica, cujos motivos, naquele momento, explicam-se tanto pela desestruturação do patriarca como por questões históricas. A história de cada uma delas diz muito sobre a condição da mulher naquele momento, e ilustra a situação das que ficaram solteiras, viúvas ou órfãs, colocadas numa zona de exclusão pelo modelo da família patriarcal. O casamento, geralmente acertado pelos pais, representava a aspiração da maior parte das moças e lhes possibilitava prestígio social, tendo em vista que o reconhecimento social da mulher se dava pelo marido, que substituía a autoridade paterna. Reproduzem também a história das que suportaram casamentos fracassados em nome da representação social ou das dificuldades que uma separação então implicava. Um rápido olhar sobre a história dessas personagens, ilustra bem a realidade dessas mulheres.

As duas irmãs, D. Inacinha e Sinhá-Rola, ambas solteiras, têm sua sorte definida pelos excessos do pai, que se entrega ao jogo e assim consome todos os bens da família para fazer face ao pagamento de dívidas. Da Corte dava ordem de venda de partes da sua propriedade rural, de modo a usar o dinheiro nos salões de jogo da capital do Império. Assim foram desaparecendo casas, gado e lavouras,

${ }^{174}$ OTSUKA, Edu Teruki. Espírito rixoso: para uma reinterpretação das Memórias de um sargento de milícias. In: Revista do IEB n 44, fev 2007, pp.105-124. 
que tinham visto ganhar com esforço e com o sacrifício constante de sua pobre mãe, morta de trabalho e de cansaço ${ }^{175}$..... mulher desiludida e atrozmente sofredora.... o homem desapegado dos seus, fechado em seu egoísmo, arrastado por suas paixões más $^{176}$.

Certo dia foram avisadas de que o pai havia morrido e tinham uma semana para sair da casa, antes que os novos proprietários tomassem posse de tudo. E numa das manhãs que se seguiram, receberam, com vergonha e embaraço, a visita do Comendador que tinha vindo buscá-las.

Dạ Virgínia, viúva e sem filhos, chega ao Grotão praticamente despossuída depois da morte do marido que, sempre embriagado, abandona os cuidados com a fazenda que ela leva como dote, e interessa-se apenas pela dominação sexual das escravas.

\begin{abstract}
Fora rápida a transformação do homem alto e de voz trovejante, de passos dominadores, que parecia estar sempre preparado para audaciosas entradas contra o gentio, cujo odor a entontecera e fizera perder a cabeça a ponto de esquecer de si mesma, da tradição de austeridade e de sóbria grandeza de sua família... Dentro de poucos anos ela sentira em seus braços o peso do homem embriagado e enfurecido pela mais triste das decadências, que fugia de sua casa para a senzala onde permanecia dias seguidos ${ }^{177}$.
\end{abstract}

Ela parece creditar sua infelicidade ao fato de ter contrariado as determinações familiares, casando-se com um homem que não havia sido escolhido pelo pai, iludida "como noiva curiosa e trêmula, levada pelos braços vigorosos de seu noivo com seu andar ágil e possante", o que reforça seus ressentimentos e a rigidez que defende. Apesar de manter as terras, sente-se forçada a abandoná-las por não ter escravos para trabalhar nelas. Quando o marido morre, assistido pelo oficial de justiça que os havia perseguido até o "casebre onde se tinham refugiado", veio para o Grotão, "enlouquecida de dor e de humilhação".

É interessante observar que a infelicidade nas experiências conjugais é muito frequente em todas as referências feitas aos casamentos dos homens livres. Como aponta Antonio Candido no referido estudo, para os brancos, os casamentos representavam uniões subordinadas a interesses entre grupos no intuito de formar "um poderoso sistema de domínio econômico e político e, portanto, de aquisição e manutenção de prestígio e status".

\footnotetext{
175 PENNA, Cornélio. A menina morta. In: Romances Completos. Rio de Janeiro: Nova Aguilar, 1958, p.806.

176 Ibidem, p.1221.

177 Ibidem, pp.813-814.
} 
Tendo em vista que não são questões afetivas ou desejos que motivam os indivíduos, mas alianças de poder, a sociedade patriarcal transforma a mulher em moeda de troca, distinguindo-a pela obediência, contenção e por seus dotes atrativos. Além de favorecer alianças políticas e econômicas, os casamentos entre parentes reafirmam ainda a imagem de superioridade que as famílias dos proprietários têm de si mesmas, o que é claramente percebido no romance através da indignação de $D^{a}$ a Virgínia em relação à família de $D^{a}$ a Mariana.

No caso de Celestina, ela chega ao Grotão contando com apenas duas apólices da Dívida Pública do Império e com a caridade dos parentes depois da morte da mãe, cujo sofrimento de longos anos levou a uma "anemia vitoriosa de todos os remédios" ${ }^{178}$. Filha de criadores de gado empobrecidos com a chegada do café em sua região tem uma vida "cercada de desastres, acompanhando o pai na descida fatal até sua morte prematura". Seu sentimento de desamparo é de tal ordem que chega a desejar ser paralítica ou portadora de alguma doença grave para ser adotada por alguém, o que mostra que, para além do romantismo que a caracteriza, se coloca sempre a relação de dependência como alternativa, pois não se percebe como sujeito da própria vida. Perseguida por suas culpas, parece exorcizá-las através da religião, de forma a viver plenamente sua humilhação. 0 próprio livro que carrega consigo indica essa sublimação: "Prière d'une âme coupable, mais repentante $^{\prime 179}$. Não temos acesso à história de seu pai, uma vez que as poucas referências à sua vida pessoal anterior à vinda para a fazenda, dizem respeito apenas a sua mãe.

Já $D^{a}$ L Luísa ou Dạ Frau, como é chamada a governante alemã, embora integre, em tese, a chamada "família periférica", distingue-se dela fundamentalmente por ser a única que recebe salário. Ela é como um contraponto dentro do grupo das agregadas e é vista como inferior na hierarquia social forjada por elas, o que fica patente quando adoece. D. Inacinha chama para atendê-la o médico dos escravos, indicando que todo trabalho estava associado à condição de escravo. A Senhora tampouco faz qualquer distinção entre ela e as agregadas, tratando-a do mesmo modo que o faz com as outras personagens. Alvo das maledicências das outras moradoras, a governanta está sempre desconfiada e deslocada, e

\footnotetext{
178 Ibidem, p.1031.

${ }^{179}$ Oração de uma alma culpada, mas arrependida. (Tradução minha)
} 
se ressente por não dominar os códigos de sociabilidade ali vigentes. Ela é a única que percebe as relações distorcidas criadas pela escravidão, assim como que a ela se deve o comportamento altivo dos proprietários.

Podemos pensar a personagem de Dạ Maria Violante, a senhora que vem do Rio de Janeiro com Carlota, como a representação do momento de aproximação do agregado, impelido pelo desejo de proteção junto a uma família rica, e iludido com a garantia de estabilidade que essa em tese Ihe proporciona. "Viúva pela segunda vez, não fora muito feliz em suas experiências conjugais. Seu marido fora funcionário da Secretaria de Estado do Império e a deixara com pensão reduzida"180. Logo que chega do Rio de Janeiro com Carlota, deslumbra-se com a vida na fazenda e solicita sua permanência ali, sem qualquer consciência do ônus desta sua escolha.

Talvez seja mais esclarecedora a contraposição do lugar representado pelas agregadas, se pensado o caso de Manuel Procópio, primo do Comendador e único homem que compõe o grupo de agregados moradores na fazenda. Não temos informações sobre sua vida anterior à chegada no Grotão, assim como só temos acesso à sua interioridade em um único momento. "Sua presença ali ninguém mais sabia explicar, pois ele próprio não contava de onde viera nem por que agora era solitário e mudo conviva que somente fazia suas aparições às horas das refeições"181. É quando vai visitar o túmulo da menina que adentramos seus sentimentos e percepções do mundo em que vive:

Era uma falta imensa, um vácuo, um malogro de tudo que pudera esperar, que obscuramente deixara penetrar em seu coração fechado e endurecido. Era a criança alegre que dormia ali, diante dele, atrás daquela pedra, e ele que nunca se abaixara para a erguer do chão, em um misto de ser repelido, de desdém por essa manifestação de carinho e de revolta em seu orgulho de homem decaído até a condição de parasita. (...) Devia ser impossível sair dali, interromper aquele sonho que o fazia viver intensamente e voltar para a casa, mergulhar de novo no abandono interior absoluto em que vivia, no isolamento sem remédio daquelas horas intermináveis que teria ainda de existir, à espera da cegueira, da paralisia, ou da loucura senil... ${ }^{182}$

180 PENNA, Cornélio. A menina morta. In: Romances Completos. Rio de Janeiro: Nova Aguilar, 1958, p.1102.

${ }^{181}$ Ibidem, p.782.

182 Ibidem, p.798. 
Embora tenha papel definitivo no amparo à Carlota enquanto ausente o pai, e na organização e retomada dos trabalhos da fazenda depois de alforriados os escravos, nesta única referência notamos que, como as demais agregadas, ele se reconhece na condição de favor, mas não cogita romper os laços que o aprisionam, condenando-se a viver como sombra. Diferentemente delas, no entanto, ele tem mais autonomia e não parece tão subjugado às determinações do proprietário. Interessante notar que, mesmo contido, é o único que deixa transparecer certo afeto pela jovem herdeira.

Mas se a decadência econômica de todos os personagens tem como resultado o benefício do acolhimento este implica, em contrapartida, retribuição e fidelidade àquele que os protege. Como coloca Maria Sylvia de Carvalho Franco, "A lealdade inclui o reconhecimento do benefício recebido, o sentimento de gratidão e o imperativo de sua retribuição equivalente". ${ }^{183}$

A identificação com os proprietários e a necessidade de distinguir-se dos negros para não serem confundidos com eles faz com que não tenham consciência da sua situação, muito embora sejam cientes da fragilidade dos seus vínculos no caso de violadas as condições que os unem. A possibilidade de rompimento da continuidade das relações ali estabelecidas, e o temor, que vem da impotência destes personagens frente a seu destino, se traduzem no sentimento de iminência de algo indefinido e terrível que os ameaça e, faz com que reafirmem os valores de dominação, projetando na figura do Senhor sua única possibilidade de salvação.

... havia um princípio de desagregação, de ruína e desmoronamento que todos suspeitavam, e olhavam para o dono da casa como o único capaz de salvá-los, de tornar a fazer reviver e galvanizar aquele grande corpo que lhes parecia agonizante, agitado pelo trabalho subterrâneo da morte ${ }^{184}$.

Como aponta ainda Maria Sylvia de Carvalho Franco,

o caráter prescindível desse sujeito na estrutura socioeconômica, essa existência dispensável levou-o, em última instância, a conceber sua própria situação como

\footnotetext{
183 FRANCO, Maria Sylvia de Carvalho. Homens Livres na Ordem Escravocrata. São Paulo: UNESP, 1997, p.93

184 PENNA, Cornélio. A menina morta. In: Romances Completos. Rio de Janeiro: Nova Aguilar, 1958, pp. $823-824$
} 
imutável e fechada, na medida em que as suas necessidades mais elementares dependeram sempre das dádivas de seus superiores ${ }^{185}$.

Marginalizados do mundo do trabalho, ficam presos à sua condição, e tudo o que Ihes resta é a revolta solitária. Vivem atormentados, remoendo culpas e ressentimentos por não serem favorecidos como os parentes que os acolhem, e estabelecem relações hostis entre si, competindo pelo favorecimento e, assim, sublimando a humilhação em que vivem.

Mesmo entre as irmãs há rivalidades. A mais nova chega a falar da irmã, Da. Inacinha, "como eterna e querida adversária" pois tributa a ela sua infelicidade por ela the ter desaconselhado o casamento com o único pretendente que teve. Os traumas e as rupturas não são elaborados, e assim são trazidos ao presente tal como se configuram no passado e, portanto, não superados.

O trabalho, base de toda formação social e atribuído ao escravo desde a Colônia, é representado no romance de forma realista e identificado à servidão. Isto explica o desejo de pequenos proprietários de terra, como os antigos Senhores de José Carapina, de possuírem escravaria mesmo sendo quase tão pobres quanto eles, ou o de Celestina que vislumbra a possibilidade de comprar uma escrava de ganho com as suas economias para emancipar-se. Nem ela nem qualquer dos outros parentes recolhidos aventam a possibilidade de ganho a partir de seu próprio trabalho, de acordo com o que ocorria então. É ilustrativa a rememoração de $\mathrm{D}$ ạ Virgínia do tempo em que, para salvar o resto das terras recebidas como dote, teve que trabalhar. Diz ter tido "as mãos manchadas pelos trabalhos mais degradantes, feitos às ocultas até mesmo da gente das lavouras, que não deviam saber do grau de miséria e decadência atingido por sua Sinhá" ${ }^{186}$, demonstrando a desvalorização do trabalho, visto como humilhação e vergonha.

Cabia às mulheres a execução e supervisão das atividades domésticas, o que explica inclusive a ociosidade do velho agregado. Enquanto vivo o Comendador, a não ser quando acompanha Da Virgínia à Corte para buscar Carlota, ele praticamente só entra em cena nas conversas no alpendre e nos jogos depois do jantar.

\footnotetext{
${ }^{185}$ Cf. FRANCO, Maria Sylvia de Carvalho. Homens Livres na Ordem Escravocrata. São Paulo: UNESP, 1997, p.111

186 PENNA, Cornélio. A menina morta. In: Romances Completos. Rio de Janeiro: Nova Aguilar, 1958, p. 814
} 
Por não se constituir como obrigação regular, talvez pudéssemos falar antes em ocupação do que em trabalho quando nos referimos às atividades destas mulheres nãoescravas e não proprietárias, exceção feita à governanta. Suas principais atividades ligam-se ao bordado, à confecção de roupas para uso dos habitantes e dos escravos e, esporadicamente, à cozinha. Cabe a elas também, seguindo uma determinada ordem hierárquica, substituir a dona da casa quando ausente, ou nos momentos em que esta deixa de ocupar-se da coordenação das tarefas domésticas.

O fato de não serem elas as responsáveis pela execução dos trabalhos é de tal modo estabelecido e interiorizado, que ao se juntarem às negras da fazenda, como quando vão verificar o tingimento dos tecidos ou a fabricação de azeite para as luminárias, são vistas por elas com estranheza: "Que alívio seria vê-la deixar a cozinha e ir para a sala que é lugar de branco... mas eles são tão esquisitos que até serviço de negro gostam de fazer como divertimento!", afirma a cozinheira incumbida do serviço, em uma passagem que revela a percepção do trabalho: compulsório e obrigação dos negros.

As relações entre os escravos são representadas de forma menos violenta e mais solidária do que aquelas entre os agregados, apesar da hostilidade que muitas vezes manifestam em função das hierarquias étnicas e insinuações de superioridade e de distinção que eles se atribuem, e que pareciam vigorar então. Ao lado da idade, que se impõe como critério de respeito baseado possivelmente nas tradições africanas, em que os mais velhos são respeitados em função do conhecimento acumulado de que são depositários e pelo culto que devotam aos ancestrais distinguem-se, inclusive com relação a certas regalias, os escravos de dentro quando comparados aos do eito, assim como os pajens e amas de leite dos proprietários e seus descendentes.

É interessante observar como, no episódio em que as negras são surpreendidas ao tentar visitar a igreja onde a menina estava enterrada, se insinua uma falta de solidariedade que não se concretizará, numa imagem pungente e de muita força expressiva:

Caminhavam mudas, muito unidas, formando um só bloco esbranquiçado que se movia pesadamente nas trevas. Era um dragão fabuloso, cheio de escamas e de protuberâncias, todo de cinza e preto, que se agitava seguro e muito rápido em marcha espectral, parecendo não tocar no solo da estrada com seus pés múltiplos e quase invisíveis. Agora estavam todas caladas, o pensamento fixo no desejo de chegar logo e tudo se desfazia diante delas e para trás nada ficava. Cada uma era só a 
ideia, o pequeno mundo fechado, trancado sobre si mesmo, onde palpitava apenas a vontade de ver onde dormia para sempre a Nhanhãzinha.

De repente, (...) ouviu-se prolongado grito vindo de longe. (...) Agora os clamores eram diferentes, muito altos e mais articulados e já não era possível não distinguir as palavras. Houve uma hesitação, alguns grunhidos como de animais que protestam contra os golpes do aguilhão e a massa parecia querer desfazer-se em pequenos grupos. O movimento já não era o mesmo, monótono e rápido, inconsciente de sua própria força e obstinação. (...)

Era agora a ordem seca, fulgurante, chicoteante, e mesmo as mais moças e mais afoitas pararam e todas elas instintivamente se afastaram umas das outras, desvanecida a solidariedade intensa que as unira. Estavam agora sozinhas e isoladas, sem defesa, diante do poderoso feitor e cada qual sentia confusamente que devia reunir suas forças para conseguir o perdão, para explicar, para desfazer e afastar de si a tempestade iminente, o castigo e o sofrimento que sabiam esperá-las. (...)

Cercadas pelos três homens as mulheres se uniram de novo, mas, pelos braços cruzados sobre o peito e pelas cabeças trêmulas e curvadas, via-se bem que não era mais um bloco que tomava o caminho de retorno. Cessara a vida que as unira, que fizera liga entre aqueles corpos negros agora envelhecidos e cansados... (...)

As negras logo que chegaram ao amplo terreiro, dirigiram-se para a porta dessa sala, aberta de par em par, e nela entraram sem murmúrio, sem que tivessem hesitado um só instante e ajuntaram-se no canto mais afastado, encolhidas e silenciosas. Seus olhos brilhavam e lançavam olhares mortais umas às outras, onde se liam acusações alucinadas, ferozes e sem perdão, e os grossos lábios arroxeados tremiam, agitados por muitas maldições. Os corpos se tocavam, e o cheiro que deles se desprendia era sufocante, acre, mas eram inimigas as carnes que se uniam, e as almas entravam em guerra de morte. Muitas prometiam a si mesmas sangrentas vinganças e fariam todo o mal possível às companheiras que ali estavam, inermes e transidas como elas próprias! Tudo seria possível, tudo se faria, de faca nas mãos e o riso da demência nos lábios abrasados... quando passasse aquele momento de pavor! Mas em meio da loucura que fazia ferver as suas pobres cabeças, as negras, em algum canto recôndito e intocado de suas almas tumultuosas, que permanecia tranquilo e consciente, tinham a certeza de que nada fariam quando saíssem daquele inferno, e continuariam a viver e a rir, sempre juntas! ${ }^{187}$

Embora formem um bloco único e articulado, de modo a dar a impressão de constituírem um só corpo determinado por um mesmo objetivo, sem consciência da sua própria força e, diante da ameaça de punição, aquele corpo se fragmenta. Para compensar o terror em que se encontram, elas se dispersam em busca de alternativas individuais. Canalizam sua revolta em direção às outras a quem atribuem sua participação, sabendo, no entanto, tratar-se apenas de um sentimento momentâneo. Podemos pensar assim que esse movimento de aproximação e afastamento das escravas alude à escravidão como força, ao mesmo tempo, aglutinadora e dissolvente.

187 PENNA, Cornélio. A menina morta. In: Romances Completos. Rio de Janeiro: Nova Aguilar, 1958, pp.801-803. 
As diferenças entre os escravos da casa-grande e os do eito, assim como entre os cativos e forros figuram no texto como apenas de pequenos privilégios, sendo igualmente reificados e tratados com a mesma desconsideração e violência.

Conforme ensaio do historiador Rafael de B. Marquese, as alforrias concedidas em grande número no Brasil, podem ser pensadas como um procedimento que teve como efeito abrandar os conflitos sociais entre escravos e senhores, evitando movimentos de resistência coletivos, como os que ocorreram no Caribe inglês e francês, ou mesmo em Pernambuco no século XVII. Presente desde os primeiros anos da Colônia, a manumissão se dissemina a partir de fins do século XVII, transformando-se, no Brasil, em instrumento de manutenção da ordem escravista. Compensada com a entrada massiva e constante de negros recém-chegados, não chegava a se constituir como perda significativa. "Por conta da dinâmica do tráfico para o Brasil, o mais volumoso na história do comércio negreiro transatlântico, o africano escravizado era uma mercadoria socialmente barata" ${ }^{188}$.

Os benefícios da alforria no Grotão, como com frequência no mundo rural, eram mais simbólicos do que os objetivamente conquistados em termos materiais, o que é exemplarmente representado no romance. Refiro-me à cena em que Libânia, ama-de-leite e babá da menina, ao ser impedida de acompanhar o cortejo e o enterro, rasga sua carta de alforria, consciente de que esta não lhe garante nem mesmo a liberdade de acompanhar o féretro. Ela guarda os pedaços, no entanto, provavelmente por reconhecer que embora continuasse prisioneira da situação, a carta mesmo rasgada poderia lhe ser útil para provar sua condição distinta da dos outros escravos, ou ao menos para ser reconhecida por eles como superior, pois liberta. Nesse momento ela pensa em fugir ou morrer o que, em tese, mostra-se como grande contradição, pois a princípio é livre.

Em outra passagem é Joviana que desdenha da sua liberdade e diz: “Eu estou fôrra... eu estou fôrra... eu estou fôrra... a negra velha nunca será fôrra... nunca será fôrra... será

\footnotetext{
${ }^{188}$ Cf. Rafael de B. Marquese em A dinâmica da escravidão no Brasil - Resistência, tráfico negreiro e alforrias, séculos XVII a XIX. Novos estudos - CEBRAP no. 74. São Paulo. Mar. 2006. P.10 Nesse ensaio, Marquese aponta a questão das alforrias concedidas em grande número aos escravos negros e mulatos nascidos no Brasil, e a intensificação do tráfico negreiro transatlântico, como mecanismos que, somados à institucionalização da figura do capitão-do-mato e de uma legislação repressiva dura, evitaram movimentos de resistência escrava coletivos, como os ocorridos no século XVII.
} 
sempre escrava de sua Sinhàzinha"189. Ela está forra, mas nunca será forra. E como para reafirmar esta condição dos escravos libertos, declara o narrador ao falar de uma antiga mucama da Senhora: "Muitas que tinham sido alforriadas, comprando com seu próprio dinheiro a carta de liberdade, permaneciam em suas obrigações antigas e recebiam muitas vezes os castigos distribuídos às escravas". 190

Diferentemente do que acontecia nos centros urbanos ou nas atividades em que, gozando de mais autonomia os cativos tinham mais condições de resistir ao controle senhorial - como na mineração - com exceção de alguns pequenos benefícios, de pouco valiam as cartas de alforria nas grandes propriedades rurais. Explicita-se assim que a concessão de alforria é uma prática que legitima a escravidão, uma concessão do poder senhorial, pois se de um lado simboliza possibilidades de mudança de posição social, por outro, não coloca em questão a natureza do sistema. A própria denominação, que distingue os homens livres dos libertos, indica a profunda diferença que há entre eles.

Mas a hierarquia ali não se limita à questão social. Forjam-se critérios hierárquicos e níveis de distinção, criando diferenciações para reforçar as estruturas do poder patriarcal, e provocar a hostilidade e a rivalidade entre os moradores. Dentro da casa, a forma com que se dispõem à mesa já denota esta estrutura, além de apontar para as distinções entre o masculino e o feminino, como apontado por Luiz Costa Lima ${ }^{191}$. De um lado estão os parentes do Comendador, respeitado primeiro o critério de gênero e depois o da ordem de proximidade de parentesco: o primo Manoel Procópio, a prima Virgínia, as duas irmãs e os visitantes ocasionais; do outro, Dạ Mariana, sua prima Celestina e, em seguida, os lugares vazios dos três filhos do casal, ausentes e identificados à linhagem da mãe. A governanta, a quem cabe a supervisão dos trabalhos da casa assim como a educação das crianças não se senta à mesa com a "família".

Como ilustração das relações estabelecidas, na parede do fundo da sala de jantar, há um painel em que figura uma cena "onde carruagens, cavaleiros e cães de caça corriam em

\footnotetext{
${ }^{189}$ PENNA, Cornélio. A menina morta. In: Romances Completos. Rio de Janeiro: Nova Aguilar, 1958, p.1035.

190 Ibidem, p. 1026.

191 LIMA, Luiz C.O romance em Cornélio Penna. Belo Horizonte: UFMG, 2005. 2a ed, revista e modificada, p. 112.
} 
diferentes direções" ${ }^{\prime 192}$, todos em busca de sua presa. Além do simbolismo contido no detalhe do papel de parede, é interessante observar como a narrativa é construída por acumulação e de forma metonímica, se é que podemos falar nesses termos. Assim, por exemplo, a descrição do papel que ornamenta a sala de jantar da casa-grande é apresentada inicialmente apenas como um detalhe do ambiente.

Celestina ficou parada no alpendre e olhou para dentro, como se visse ainda aquela figura toda de negro, mas na sala da capela aberta diante de seus olhos e na nesga da de jantar, tão grande, com seu papel onde carruagens, cavaleiros e cães de caça corriam em diferentes direções, nada mais se via. ${ }^{193}$

O motivo é retomado alguns capítulos depois, quando duas das parentas passam pela sala, estabelecendo, de modo sutil, uma relação entre as cenas. É então que nos damos conta de que seu significado vai muito além da mera descrição:

Enquanto caminhavam para o jardim Sinhá Rola e Celestina atravessaram primeiro o corredor, agora deserto, depois a grande sala de jantar onde a vida dos personagens do papel de parede, fidalgos saídos de seus castelos para subir em carruagens ou montados em seus cavalos fogosos, para uma caçada agitada e feroz aos cervos e corças a correrem em todas as direções, punha nota fantástica no silêncio reinante na casa toda, e, finalmente, desceram as escadas em direção ao recinto fechado entre grades, onde estava o jardim de Carlota ${ }^{194}$.

As figuras tornam-se personagens com vida e os fidalgos perseguem ferozmente suas presas, da mesma forma que na casa, onde todos se observam para aproveitar de um momento de descuido da presa e caçá-la. A interdição, o controle entre os habitantes da casa-grande é permanente, e sobre todos paira ainda a autoridade e o controle do Comendador. Muitas páginas adiante retorna o motivo:

Parecia a Carlota estar prisioneira, e atrás daquela porta vigiavam duas guardiãs para não a deixarem passar. O círculo diminuía sempre, e tudo à sua volta tornava-se cada vez mais entrelaçado, e até o silêncio envolvente parecia-lhe espesso e denso. Quando o cansaço de conter-se, de suportar todo o tumulto do sangue corrente em suas veias na exigência constante de movimentos e gestos violentos, e era verdadeira caçada real, perseguido e perseguidores, onça em desespero e matilha embravecida pela correria o que sentia em todo o seu corpo, quando tudo aos poucos se acalmou, ela refletiu sobre os sentimentos causadores de tamanha exaltação. E nada pode concluir, nenhuma luz se fez em seu espírito ${ }^{195}$.

\footnotetext{
192 PENNA, Cornélio. A menina morta. In: Romances Completos. Rio de Janeiro: Nova Aguilar, 1958, p.892.

193 Ibidem, p.892.

194 Ibidem, p.939.

195 Ibidem, p.1154.
} 
Temos então a narração dos sentimentos da personagem que retoma o padrão do papel para expressar sua sensação de aprisionamento e identificação com os oprimidos, e explicitar não apenas a importância do detalhe, mas ainda a forma como o autor constrói a narrativa.

Finalmente surge a imagem da onça, agora claramente atribuída à senzala, em uma cena que se segue à tomada de consciência por parte de Carlota da ameaça de confronto entre proprietários e escravos. O tema de uma potencial insurreição destes surge em diversos momentos, e antes de partir para a Corte o Comendador entrega armas

...aos feitores e aos guardas, com a recomendação de atirar ao primeiro sinal de revolta.

Atrás daquelas janelas à sua vista de esconso se desenrolavam mil pequenos dramas, mil tristezas, todos dominados pelo tédio minucioso da solidão, do afastamento da fazenda, perdida em meio de culturas imensas e de matas inextricáveis, cercadas pelos mistérios de todos os momentos dos negros que os faziam viver, escondidos na senzala que via ali defronte agachada, pronta para o salto da onça, mas agora quase rosada pelo sol da tarde ${ }^{196}$.

A violência figura como ameaça constante por parte dos fidalgos que partem com seus cães para a caça de corças e cervos que, no entanto, temem um possível ataque da onça. Mas a onça que ameaça pode vir da senzala, onde estaria sempre agachada e preparada para o ataque. Ela se insinua ainda dentro da herdeira, indicando sentimentos contraditórios em Carlota com relação àquela estrutura. Ao mesmo tempo que proprietária, ela também é oprimida e identifica-se aos oprimidos pelo regime servil.

Além de indicar como a tensão está presente entre todos, o conjunto dos excertos evidencia um recurso muito utilizado na construção do texto, em que os mesmos temas são abordados em diferentes situações e personagens, visando à formação de um sentido, por acumulação. Em outras palavras, o autor retoma as mesmas questões, reafirma os mesmos sentimentos, criando imagens que vão se acumulando durante a leitura, e que chegam às vezes até a uma saturação que oprime o leitor.

A repressão e o controle são questões bastante evidenciadas no texto. Às mulheres brancas não era permitida a saída sem acompanhante nem mesmo da residência. No entanto, a governanta não está sujeita à mesma determinação, o que indica a vinculação da

196 Ibidem, p.1103. 
posição social à dominação feminina. Tudo é interdito, e não há lugar para afetos ou prazeres, seja no que diz respeito à sociabilidade, ou ao sexo, cujo tratamento formal chama a atenção no romance. Abordado de maneira sutil, traduz a repressão dominante. É ilustrativa a cena em que o Comendador, ao adentrar a sala em que sua filha está sendo velada, sente não ser digno de tocar nela por trazer de fora a lama e a podridão dos brejos e das terras frementes de seiva.

Deu alguns passos, e o ruído martelado de suas botas, o tilintar das esporas, pareceram-lhe sacrílegos. Sentia, confusamente, ter trazido lá de fora a lama e a podridão dos brejos e das terras frementes de seiva presas aos seus sapatos e reconheceu não serem suas mãos dignas de tocarem naquela figurinha de cera ${ }^{197}$.

Ao referir-se à fecundidade da terra, e ao caracterizá-la do modo como o faz, o narrador amplia o significado da sua afirmação e permite uma leitura que vai além da promiscuidade da esfera da intimidade com o mundo do trabalho. O desejo fremente de ser fecundado que se localiza no espaço de fora da casa e que não é digno de figurar no espaço interno, pois sujo, pode ser entendido também como o que se opõe ao sexo legitimado, com finalidade de reprodução e destituído de desejo que, em grande parte das vezes, caracterizava o relacionamento dos senhores. Não bastante, o barulho das botas e das esporas reafirmam sua virilidade e reforçam a observação. Utilizando o recurso da acumulação apontado ao falar sobre a simbologia do papel de parede, muitos capítulos depois ele vai retomar a imagem, associando agora claramente a figura do patriarca como centro de poder e figura que dá origem àquele mundo. Não só ele, mas aqueles que ele gera vêm ao mundo ricos de seiva para se multiplicar e prolongar seu poder.

Aquela presença masculina, poderosa, fonte e origem em potência de muitas vidas, que viriam ao mundo ricas de seiva e se prolongariam e multiplicariam pelos séculos, era bem a do patriarca dominador de todo aquele grupo de homens e mulheres, era o tronco da árvore sem medida cujos galhos se reproduziam sem cessar ${ }^{198}$.

A necessidade de recato aprisionava a mulher branca em um modelo de mulher casta e obediente, e Ihe atribui uma frieza que se opõe à sensualidade das mulatas e negras. A legitimidade do assédio e da prática sexual entre brancos e escravas evidencia-se na própria arquitetura da casa-grande, que prevê a liberdade de entrar e sair dos homens cujos aposentos, diferentemente dos das mulheres, possuíam entrada independente. Observa-se

\footnotetext{
197 Ibidem, p.748.

198 Ibidem, p.1058.
} 
que o texto faz referências claras a esses relacionamentos na história de $D \underline{a}$ Virgínia, cujo marido só se ocupava com o domínio sexual das escravas, na das irmãs, cujo pai também se entregou ao jogo e a uma vida de prazeres e na de Florêncio, filho de um proprietário com uma escrava.

No Grotão, o uso do sexo como forma de dominação é sugerido apenas por indícios e subentendidos, como quando as escravas conseguem uma licença oficiosa para irem até a igreja ${ }^{199}$, quando o Comendador vai em direção à senzala das mucamas, ou quando alguma das moradoras percebe movimentos estranhos na casa. Certa madrugada Carlota vai para o pátio e distingue "furtiva silhueta de homem branco a sair das dependências para se dirigir ao alojamento dos hóspedes, onde desapareceu silenciosamente"200. Em outra ocasião, Celestina, ao ouvir alguém passar pelo seu quarto, vai até a sala e, ao verificar a porta aberta para o jardim, recua com "medo de surpreender algum segredo de homem que a faria envergonhar-se de si mesma".

O recalque sexual também está presente e transparece, por exemplo, quando Sinhá Rola é surpreendida por um cisne que a faz cair e aterrorizar-se, parecendo-lhe "um monstro gigantesco, branco", que se aproxima para matá-la. ${ }^{201}$ É curioso observar que seu nome também é de uma ave e, quando jovem, a velha senhora era chamada de Rolinha, apelido que Ihe foi atribuído em função do seu colo branco e rijo. Podemos referir ainda o episódio do touro, em que as mulheres apavoradas se lançam pelo barranco, caindo no fundo de uma vala. Diz o texto:

Celestina sentia-se presa pela terra, não podia erguer os pés que se tinham tornado pesado e mortos, e esperava a todo o momento por sôbre a sua cabeça surgir a sombra enorme do touro que se precipitava sobre ela e a esmagava com seu corpo agigantado ${ }^{202}$.

\footnotetext{
199 Ibidem, p.799.

200 Ibidem, p.1225.

${ }^{201}$ Cf. Wander Melo Miranda, que aponta o touro e o cisne como símbolos da sexualidade latente e da interdição de torná-la manifesta. A Insuportável Comédia. Dissertação (Mestrado Faculdade de Letras) UFMG. 1979. P.74.
}

202 PENNA, Cornélio. A menina morta. In: Romances Completos. Rio de Janeiro: Nova Aguilar, 1958, p.911 
Todos ali sofrem. Seu sofrimento, provocado por uma dor difusa e por um sentimento de incompletude, é projetado no mito da menina que morre prematuramente. Sempre referida como benevolente, piedosa e alegre, ela parece figurar como símbolo de uma esperança que não se realiza. É sintomático que com o anúncio oficial do casamento de Carlota o Comendador retire e guarde o quadro, pois sua memória perde a funcionalidade. A nova união vai passar a figurar como símbolo de uma nova esperança, uma esperança que se faz e se desfaz em um movimento que tende a se repetir, mas que não se completa. A esperança, uma das virtudes teologais, se explicita como compensação aos moradores, e está ironicamente inscrita no próprio brasão da família: Spes et labor ${ }^{203}$.

A menina paira então como um fantasma na casa, e ao mesmo tempo que condensa um sentimento de falta, presentifica a ameaça da morte. Embora funde a narrativa, como se inaugurasse um drama que está por se desenvolver, temos indicações de que sua morte apenas descortina o que já vinha sendo vivido ${ }^{204}$ não constituindo, portanto, as causas do sofrimento dos moradores.

A apatia de Dạ Mariana, por exemplo, já lhe é anterior: “Quando Carlota fora para o colégio da última vez a Senhora tinha se retraído há muito tempo e vivia fora inteiramente dos amigos, das visitas costumeiras que o Comendador recebia muito afavelmente, mas constrangido por inexplicável embaraço". ${ }^{205}$ Suspeitam inclusive estar ela doente, pois só a doença justificaria, pelo olhar das outras mulheres, que não cumprisse o papel de direção da casa, subserviente ao marido, e representando uma felicidade ao menos aparente. 0 aparecimento da menina, segundo Celestina, dá-se quando "todos da fazenda já estavam mais velhos e cansados, e viviam sozinhos entre eles, já separados pela experiência da vida e suas amarguras ocultas" 206 .

\footnotetext{
${ }^{203}$ Esperança e Trabalho (tradução minha). Se lembrarmos da inscrição igualmente cínica exibida na entrada de vários campos de extermínio nazistas, "Arbeit macht frei" (o trabalho liberta), podemos pensar que esta notação seja uma analogia, que o autor propõe, aos campos de trabalhos forçados.

${ }^{204}$ Cf. já observado por José Aderaldo Castello. CASTELLO, José Aderaldo. A literatura brasileira - Origens e unidade. Vol. II. São Paulo, EDUSP, 2004, p.325.

205 PENNA, Cornélio. A menina morta. In: Romances Completos. Rio de Janeiro: Nova Aguilar, 1958, p.848. 206 Ibidem, p.940.
} 
Sabemos que Carlota nasce quando os dois rapazes já são internos no colégio e só vêm para a fazenda nas férias, da mesma forma que a menina agora morta, que nasce quando Carlota já estuda no colégio francês na Corte. A infância de Carlota "trouxera alegria incomparável a todos com seu gênio buliçoso, mas suave", assim como a da irmã. Esta segunda menina, que também achara a casa vazia de crianças, "não pudera reanimar os rostos perturbados vindos ao seu encontro, e vivera entre os maiores como aquelas florinhas entre os arbustos e as árvores, sem nunca poder comungar inteiramente com eles", do mesmo modo que se apresenta a única lembrança da mãe a que Carlota faz referência:

... figura mutilada de rainha distante, desdenhosa, de quem não era possível aproximar-se sem provocar irritação e gestos de defesa. Era sempre a mesma sensação de sacrilégios que fazia seus dedos se encolherem, suas mãos estendidas para um carinho caírem desanimadas, e sua boca sequiosa de um contato quente fechar-se, apertados os lábios até ficarem lívidos ${ }^{207}$.

Carlota é chamada de volta do colégio para ocupar o lugar deixado pela menina agora morta e todos, dependentes e escravas, se dão conta disso. Fica claro que ir ao colégio era uma condição subordinada aos interesses e conveniências do patriarca. Considerada elemento de distinção social em uma sociedade estritamente patriarcal, a educação feminina era concebida como aprimoramento de valores religiosos e morais, com o intuito de possibilitar a competência necessária no exercício de funções condizentes com o papel de esposa e mãe.

“Era uma substituição odiosa que se ia fazer, o disfarce, a mascarada mais imperdoável da situação assim criada..."208, diz Celestina em determinado momento. "Parece quererem que a menina morra outra vez!..." ${ }^{209}$, declara Libânia em outro. São tantas as afinidades entre as irmãs, que muitas vezes a imagem delas se funde. Os personagens frequentemente sobrepõem a imagem das duas, como ocorre quando a jovem escrava acaba por confessar a Carlota que ela Ihe parecia ser a menina morta, de volta agora "grande, moça e bonita"210,

\footnotetext{
207 PENNA, Cornélio. A menina morta. In: Romances Completos. Rio de Janeiro: Nova Aguilar, 1958, p. 1075.

208 Ibidem, p .941

209 Ibidem, p.1067.

210 Ibidem, p.1011.
} 
ou quando Procópio olha para ela e balbucia: "É a mesma; é ela que volta agora..."211. A história delas coincide até mesmo no trato humanizado com os escravos, e em alguns momentos agem como se fossem a mesma. É o caso, por exemplo, de quando as meninas roubam as chapinhas de metal distribuídas àqueles que superassem a meta de sacas a serem colhidas, e que por sua vez serviam como moeda de troca para a compra da alforria.

A falta de individuação das duas meninas pode ser pensada como extensiva a todas as personagens femininas. $\mathrm{O}$ espelho de três faces, aberto para que Carlota se visse de todos os lados quando pronto o vestido a ser usado pela jovem, e habitualmente fechado à chave, ao mesmo tempo que dá uma dimensão da repressão ali vigente, pois impede que as personagens se vejam e não apenas sejam vistas, parece se apresentar como metáfora do espelhamento dessas personagens e da sua duplicação. Tanto as parentas agregadas, como as escravas e as proprietárias parecem figurar três momentos de uma mesma existência. Assim como Dạ Mariana, Carlota e a menina representariam os três momentos da vida de uma proprietária, as duas irmãs Da.Inacinha e Sinhá-Rola, Da Virgínia e Celestina representariam respectivamente a velhice, a maturidade e a juventude das parentas agregadas $^{212}$, enquanto Dadade, Joviana e Libânia representariam a velha mucama, a escrava de meia-idade e a jovem escrava, indicando mais uma vez um tempo circular que justifica, inclusive, o discurso elíptico.

Sem começo nem fim, o tempo caracterizado como cíclico poderia ser, portanto, mais um indício da perspectiva do romance, já que o movimento circular não inauguraria novos momentos e sim apontaria para uma história que se repete.

O processo de reconhecimento da família por Carlota, há anos interna no colégio, é doloroso e não são poucas as vezes em que chega a ter pena de si mesma já que, por mais que tente, não consegue estabelecer qualquer comunicação com aquele mundo.

O sofrimento da mãe e suas dores lhe parecem, inicialmente, incompreensíveis. Acredita ter sido abandonada por ela e sente-se não apenas desamparada como preterida

\footnotetext{
211 Ibidem, p.1160.

${ }^{212}$ Simone Rossinetti Rufinoni já analisa essa duplicação no caso das agregadas. Favor e Melancolia - Uma leitura de A menina morta, de Cornélio Penna. Tese de Doutorado. São Paulo: Faculdade de Filosofia, Letras e Ciências Humanas, Universidade de São Paulo, 2005. p. 67.
} 
pela irmã, cujo culto era unânime entre todos. Ainda impregnada das idealizações de quando interna no colégio, chega mesmo a iludir-se com o pedido de casamento. "Era como se dentro dela se erguesse o cântico da vida e da força, como se as portas de seu destino se abrissem de repente, e mostrassem haver agora nova razão para existir e justificar-se perante todas as dores" 213 .

Mas aos poucos vai acumulando frustrações, e começa a perceber que a ingenuidade própria da infância assim como sua posição social, propiciavam sua alienação e, portanto, uma visão distorcida da realidade e dela mesma.

Vai percebendo também a opacidade e o abafamento daquele mundo, assim como o peso da estrutura da qual ela é herdeira. Todos aqueles que procura, seja para conhecer a mãe, seja para tentar entender os motivos que a levaram a se afastar, aparentemente muito solícitos e solidários, estão de tal forma comprometidos com a ordem que ali reina e em garantir o seu lugar que, dominados pelo medo de serem punidos ou de perderem seu acolhimento, recusam-se a qualquer contribuição que possibilite a compreensão da situação e, assim, amenize seu sofrimento.

Como os outros habitantes do Grotão, Carlota tem o seu papel definido na estrutura social, assim como projetado o seu futuro, tendo em vista uma estrutura de imutabilidade que então se impõe. Podemos verificar que a personagem vai acusando mudanças, sentindo-se cada vez mais angustiada, sempre em busca de uma verdade e sempre frustrada nas suas tentativas.

E nesse processo de busca, que é também uma tentativa de compreensão e de aproximação com a imagem da mãe vai, aos poucos, se dissolvendo nela. Depois da morte do patriarca, a jovem que já vinha aos poucos desconstruindo a imagem idealizada do pai e se identificando cada vez mais com a mãe que ela percebe vítima da situação, parece encarnar o duplo de Dạ Mariana, levando os que estavam em volta a tomá-la pela outra. São muitas as indicações dessa identificação:

213 PENNA, Cornélio. A menina morta. In: Romances Completos. Rio de Janeiro: Nova Aguilar, 1958, p.1023. 
A Sra Luísa exprimiu então em voz alta o que as três pensavam, arrepiadas: -Mas é a própria Dạ Mariana que vem ao nosso encontro! ${ }^{214}$

Era agora a Senhora e tudo nela se apagara, se retraíra e entrara dentro das dimensões daquele grupo fechado, perdido nas colinas do vale do grande rio. Passou diante da mucama, e seu vestido tinha o roçagar aristocrático das vestes da antiga dona, e saiu rapidamente. ${ }^{215}$

Nhanhã, não olhe assim não para mim, pois eu fico cheia de medo... Até me parece ver outra pessoa, quando também me perguntava coisas que eu não podia dizer... (...) - Abrenúncio! A negra velha está para ficar doida! Agora me parece ter falado com Sinhá Dạ Mariana! ${ }^{216}$

Aos poucos percebe também o interesse do pretendente e sobretudo da futura sogra no acordo que o casamento implicava, estabelecido como simples contrato comercial. A Condessa, cujo marido dedica-se à política conservadora na Corte, e claramente motivada por questões econômicas, parece ser quem propõe a união. Termos como contrato, projeto e aliança entre famílias, tendo em vista ser prima do Comendador, são usados como sinônimo de casamento.

A jovem começa a tomar consciência também do comportamento do futuro marido, quando vê a violência com que chicoteia o escravo que apenas havia deixado cair uma caixa. Entusiasmada a princípio com o cavalo que recebe dele, observa ser este um animal violento, pois ao tentar acariciá-lo ele se assusta e começa a escoicear e bufar "ruidosamente, as narinas muito abertas e os olhos alucinados a revirarem, vertiginosamente" 217 , remetendo a uma figura diabólica, não por acaso denominado Satã. Aparentemente respondendo afirmativamente às perguntas que lhe faziam sobre ela, Carlota acaba percebendo que o animal havia sido adestrado para sacudir a cabeça de alto a baixo tão logo se passasse a mão atrás de sua orelha. "Sentiu certo desapontamento de ter descoberto com tamanha facilidade o segredo de Satã". Sugere-se então, que tal como o dono, sob uma aparência de adequação social e polidez há um ser violento que se constitui como mais um indício da realidade a que estava destinada.

\footnotetext{
${ }^{214}$ Ibidem, p.1142.

215 Ibidem, p.1107.

${ }^{216}$ Ibidem, p. 1191.

${ }^{217}$ Ibidem, p.1077.
} 
Mas mesmo perdendo progressivamente o encantamento, ela se mantém inicialmente no propósito de casar. Seu processo de transformação é lento, pois durante algum tempo duvida de suas percepções. Quando insinua ao pai que não se sente feliz como quando criança, ele reage com violência:

Parecia severo juiz diante da criminosa na expectativa da confissão do crime. Procurou no fundo de sua alma a verdade sobre seus sentimentos, porque nesse instante ódio surdo latejava em seu coração, pois era agora um homem estranho que tinha diante dela, a afastá-la com impaciência de seu caminho, e lhe parecia ser também escrava cuja venda estava em negócio, mediante condições impossíveis de serem imaginadas... Porém, tudo podia ser apenas sonho, encantamento mau a aprisioná-la cada dia e cada hora ${ }^{218}$.

Ela não tem mais as ilusões de quando volta para a fazenda, quando chega a manifestar, inclusive, desejo por ele.

Podemos perceber que os próprios nomes dos personagens são cheios de significado. O do pretendente é João Batista, aquele a quem se atribui o batismo, como prática que simboliza o ritual de iniciação ao Cristianismo e que apaga o pecado original de quem o recebe $^{219}$, e o da fazenda onde moram, Fazenda do Paraíso, lugar em que reina a felicidade absoluta desde que não se contrariem as regras impostas.

Mas é depois do passeio até a clareira, ponto que simboliza a encruzilhada da vida da mãe, que como numa revelação, parece se completar o processo de transformação da menina: “...tinha o olhar fremente que sabia dardejar agora sobre as pessoas, olhar esse que Ihe parecia o de outra pessoa e não da menina meiga e assustada vinda da Corte há poucos meses"220.

Se já percebia que seu casamento é de conveniências, agora se dá conta que a mãe é vítima do lugar que ocupa, e que ela também está ali apenas para cumprir um papel social, e orientar-se pelas determinações do futuro marido e da sogra, ou seja, da sociedade, reproduzindo uma estrutura que ela condena.

Sentira entretanto, bater dentro de si o coração seguro, capaz de aprisionar seus pensamentos em rígida fórmula, que Ihe daria forças para apoiar-se em si mesma

\footnotetext{
218 Ibidem, pp.1089-1090.

${ }^{219}$ Cf. Dicionário Houaiss da língua portuguesa.1ạ.reimpressão. Rio de Janeiro: Objetiva, 2004.

220 PENNA, Cornélio. A menina morta. In: Romances Completos. Rio de Janeiro: Nova Aguilar, 1958, p.1163.
} 
contra o mundo, e mais uma vez reconheceu ter atravessado a porta por onde iria chegar à luz do dia. Talvez por isso mesmo lhe viera o desejo de vestir aqueles vestidos, para se abrigar em suas dobras estrangeiras, no feitio e no perfume envelhecido de outro corpo, para ela desconhecido e sem elementos para o julgar, e certamente a transformariam em outra criatura. ${ }^{221}$

A violência está entranhada na realidade social e manifesta-se tão logo algum acontecimento ameace a ordem imposta. Ao querer pôr fim à situação em que vive, ao colocar em cheque a autoridade do marido, desvendando a farsa do suicídio de Florêncio, Da Mariana detona um processo em que é derrotada e cuja consequência é à loucura.

O texto não esclarece o que se passa efetivamente. Não sabemos se ao denunciar o assassinato de Florêncio a Senhora está apenas denunciando a brutalidade do marido, ou se está enfrentando sua autoridade porque tinha também algum envolvimento com o jovem escravo, o que é insinuado em algumas passagens. Tanto Sinhá Rola como Celestina lembram-se de muitas noites terem ouvido passos e ruídos sem nunca acharem explicação. Os campeiros também "contavam que muitas vezes tinham visto (Florêncio) saltar a janela do casarão, descer pelos galhos de enorme mangueira e desaparecer sem ruído na noite"222. Segundo o relato de uma velha cativa, ele nunca havia olhado para nenhuma das escravas apesar das provocações que elas Ihe faziam e, quando Libânia pede à Senhora licença para se casar com ele, ela simplesmente finge não ouvir o pedido.

A hipótese de uma relação com um escravo, filho bastardo de um fazendeiro, sempre distante dos outros cativos, poderia justificar as alusões de vergonha da família feitas pelo patriarca e por Da. Virgínia, ou a insistência de Joviana em assegurar à Carlota a inocência da mãe. Buscar a satisfação sexual fora do domínio do casamento era absolutamente condenado pelo marido e pela sociedade, diferentemente do que ocorria do ponto de vista masculino, em que a justificativa de que o homem possui uma sexualidade mais desenvolvida que a mulher, tinha reconhecimento social e até era aceita pelas esposas, desde que se mantivessem as aparências. Em um texto em que as relações não oficiais só se deixam entrever, curioso observar como não há filhos bastardos ou as chamadas "crias da casa" convivendo junto à família dos senhores, como acontecia em muitas famílias de então. No entanto, ao relatar a história de Florêncio, o romance indica que é com crueldade que as

\footnotetext{
${ }^{221}$ Ibidem, p.1265.

222 Ibidem, p.978.
} 
mulheres desrecalcam suas humilhações e frustrações. No caso, a fazendeira então viúva, vende o filho do próprio marido, que ele tinha esquecido de tornar livre.

De todo modo, seja por querer desmascarar o Comendador, seja por ter uma relação com o escravo ou até mesmo por tê-lo incentivado a assassinar o patriarca, é na noite do dia em que $D^{a}$ Mariana fala com o vigário, que há uma violenta discussão entre o casal, à qual se segue a partida misteriosa da Senhora. Não há qualquer indício que esclareça o leitor do seu paradeiro ou dos acontecimentos que antecedem o seu desligamento completo com a realidade.

Dạ Mariana fracassa, portanto, em seu projeto de resistência, e Carlota, que percebe o destino da mãe refletido no seu, empenha-se em levá-lo adiante. Nega-se a reproduzir o papel que the era reservado, recolhendo-se, isolando-se e recusando-se a contribuir como sujeito ativo daquele processo, interrompendo-o com a sua esterilidade.

Ela liberta os escravos da fazenda como ato de negação daquela estrutura perversa, que imprime a todos, inclusive a ela própria um destino inevitável e sem possibilidades de ruptura. Mas ela só o faz depois da morte do pai, e assim mesmo sob tal tensão e angústia, que chega a perder os sentidos e a adoecer. Agora ela é a herdeira legítima da fazenda e como proprietária pode fazer cumprir sua vontade, qualquer que seja.

Curioso que ao se dirigir aos escravos, em uma das tentativas de lhes comunicar sua decisão, ela se refere a eles como filhos ${ }^{223}$, reproduzindo o paternalismo que recobria o arbítrio dos senhores. Ela não estava agindo de acordo com um direito, pois os direitos são inconciliáveis com o regime de escravidão. Estava concedendo a alforria de acordo com o arbítrio senhorial, assim como eram concedidas as alforrias individuais ${ }^{224}$. No entanto, quando consegue se assumir livre da sujeição paterna e declara não estar mais noiva, ela muda de atitude e parece libertar-se também da sujeição paternalista. Mesmo que contrariando o que sente, procura afastar os vínculos de caráter pessoal e afetivo, como se quisesse objetivar aquelas relações. É assim que, quando Libânia se aproxima numa atitude

\footnotetext{
223 Ibidem, p.1266.

${ }^{224}$ Conforme Hebe M. Mattos de Castro. “Laços de família e direitos no final da escravidão". In: ALENCASTRO, Luiz Felipe de. (Org.) História da vida privada no Brasil: Império : a corte e a modernidade nacional.
} 
de proteção, ela reage confundindo a jovem escrava. "-Eu não quero que ninguém se prenda a mim... é preciso que todos possam fugir, possam libertar-se das prisões... (...) - Não estou doida", completou ainda logo depois. ${ }^{225}$

No mesmo sentido ela se refere à Sra. Luísa, liberando-a para ir embora também.

\begin{abstract}
Carlota, no entanto, teve a intuição que ela não a abandonaria (...). Quis estender-Ihe a mão, quis ir até ela e talvez beijar-lhe o rosto engelhado, no mesmo impulso de quando era menina, e recebia as inábeis e imprevisíveis provas de sua afeição, mas sentiu-se tolhida pela sensação de não ser senão pequeno detalhe no cenário onde decorria a vida da pobre criatura, e pareceu-lhe absurdo haver qualquer ternura entre elas. E deixou-a ir pois, sem se mover de onde estava, sem dizer uma só palavra. $^{226}$
\end{abstract}

Ao libertar os escravos, ela não se propõe a instituir uma nova ordem. Quer apenas destruir o que está ali. Sua recusa à ordem estabelecida se traduz num prazer pela destruição, mostrando que o que a motiva é um desejo de aniquilamento do qual se orgulha.

Carlota mantém-se alheia a qualquer iniciativa de retomada do andamento da fazenda. Ela se recolhe e parece apenas assistir à partida dos moradores e à destruição da propriedade. Ao aprisionar-se no contato com uma mãe absolutamente alienada, propõe uma libertação que transforma sua vida em experiência de morte. O romance, portanto, não alude a qualquer possibilidade de superação, mesmo quando aponta para a rebeldia de Carlota ou de Dạ Mariana, embora curiosamente sejam as mulheres que protagonizam a resistência.

Assim como os escravos libertos, ela também não se emancipa e a anulação parece ser uma resposta ao reconhecimento da impossibilidade. A alternativa ao destino que lhe é imposto e que transcende sua vontade resulta, assim, em um movimento autopunitivo que confere a este um caráter trágico, e coloca a renúncia como forma de libertação. No mesmo sentido, a perda de contato com a realidade por parte de Da. Mariana, parece indicar que as opções que se colocam aos personagens, frente a uma emancipação impossível, são a renúncia, a resignação, a loucura ou a morte, aludida como "paz e vitória sobre a vida".

\footnotetext{
225 PENNA, Cornélio. A menina morta. In: Romances Completos. Rio de Janeiro: Nova Aguilar, 1958, pp.12701271.

${ }^{226}$ Ibidem, pp.1282-1283.
} 


\section{V - Dimensão filosófico-religiosa da obra}

Este capítulo tem como objetivo abordar a articulação da dimensão histórico-social à dimensão metafísica alcançada pelo romance, em função das indicações que ele sugere. Trata-se de buscar compreender sua relação com algumas das questões filosóficas de então, uma vez que, nesta articulação, a obra parece adquirir novo sentido, inclusive no tocante à forma característica de sua escrita. Mas pretende-se apenas sinalizar o percurso de uma reflexão a ser feita, que exige uma exploração mais profunda do que comporta este estudo.

Muito embora não seja objeto deste trabalho a polêmica que se estabeleceu na crítica em torno do autor, se Cornélio Penna seria um romancista católico ou apenas um católico romancista ${ }^{227}$, ou ainda, se existe ou não um romance católico no Brasil ${ }^{228}$, até mesmo em função das dificuldades que essa classificação cria, gostaria de apontar, a partir do romance, e para além de algumas declarações essencialistas feitas pelo autor, as questões que, lidas em conjunto, me levaram a esta aproximação filosófico-religiosa da obra.

O mundo apodreceu, envenenou-se de civilização, e a poesia infelizmente seguiu-o nesse caminho, deixando de ser a expressão, o canto da infância do povo, para se tornar disfarce de velhice, ou, se quiser, arma secreta de homens de gabinete. ${ }^{229}$

(...) Detesto os intelectuais e os literatos. Afastei-me completamente ... e não podia também aprender o modo de contracenar com eles. De repente senti que tudo era mentira em minha vida, e isolei-me para não mentir, para encontrar um pouco de

\footnotetext{
${ }^{227}$ Conforme proposto por Temístocles Linhares, que ao descartar qualquer militância católica na obra de Cornélio Penna, afirma: "para nós, a despeito de seu catolicismo, o autor quis ser apenas romancista. Um católico romancista, então? Talvez, mas nunca um romancista católico, sempre fiel ao seu sentimento religioso, fazendo mesmo, implícita ou explicitamente, qualquer tipo de proselitismo ou de literatura católica militante, ainda que sejam sem conta os rumos dados em suas explorações pelos romancistas católicos. "O drama interior". In: História crítica do romance brasileiro: 1728-1981. Belo Horizonte: Itatiaia; São Paulo: Editora da Universidade de São Paulo, 1987, v.3, p.42. Apud SCHINCARIOL, Marcelo T. A arte complexa de ser infeliz: a ficção de Cornélio Penna, 2009, 370 fl. Tese (Doutorado em Teoria Literária), IEL, Universidade Estadual de Campinas, Campinas, 2009. p. 12.

${ }^{228}$ Conceito indefinido no campo dos estudos literários, como aponta ainda Marcelo T. Schincariol, "sobretudo quando se extrapola a perspectiva do sentimento religioso manifestado pelo escritor e parte-se para uma análise das implicações desse sentimento no próprio fazer romanesco, para além da questão temática". Ibidem, p. 13

${ }^{229}$ (Jornal de Letras, outubro de 1950) Apud. Apêndice. Introdução geral. Cornélio Penna Romances Completos, Rio de Janeiro; José Aguilar. 1958. p. XLVI
} 
verdade, para ao menos poder morrer de acordo comigo mesmo, e não com os outros. $^{230}$

Sobre a influência da religião na sua vida o autor se recusa a falar, alegando que o escritor só deve se dar a conhecer pelos seus livros. No entanto, diz não ver mal algum em contar que

... toda a minha vida senti ao meu lado uma presença que não sabia ver nem ouvir, mas que me trazia em perpétua angústia na mais inquieta insatisfação de mim mesmo. Cada ano, cada mês, cada dia, cada hora que se passava, representava um combate minucioso, de minutos que se travava no fundo de minha alma, sem que eu soubesse dizer como se chamavam as forças em luta. Imaginava que era a lealdade, o amor à verdade, à justiça, à solidariedade humana, que se revoltavam dentro de mim, e que o primeiro vencido era eu mesmo... ${ }^{231}$

... Chegamos a uma época em que todos os homens devem comparecer "voluntariamente" perante Deus. Dêsse contato sairá a salvação do mundo, porque estou convencido de que as soluções individuais é que determinarão o aparecimento das soluções gerais. Não é a humanidade que está errada, é o homem... ${ }^{232}$

... Vivo apenas a minha vida, e acho tão difícil, tão complicado o vivê-la, já me sinto tão cansado, só com isso, que o isolamento para mim é um refúgio e uma necessidade. ${ }^{233}$

Cornélio Penna ingressa no mundo das artes como pintor, desenhista e ilustrador ainda na década de 1920. Em 1935, quando estreia como romancista, duas linhas de força predominavam na fiç̧ão: o chamado romance social, que se configura como forma de descoberta e interpretação do país, ao representar a manifestação das contradições do conjunto da nação nas especificidades de cada região, e um movimento de orientação espiritualista ${ }^{234}$ que, herdeiro do Simbolismo, se opõe a uma perspectiva materialista e se caracteriza pela sondagem interior, pela análise de consciência, pela preocupação com os valores espirituais e morais do homem.

O decênio de 30 é com efeito, no Brasil, sobretudo em seus últimos anos, de intensa fermentação espiritualista. Do Simbolismo, da pregação católica de Jackson de Figueiredo, do nacionalismo, resultarão várias tendências ideológicas e estéticas. 0

\footnotetext{
230 Ibidem, p. XLVIII

231 Ibid. pp.LXIII-LXIV

232 Ibid. p.LXIV.

233 Ibid. p.LXVI

${ }^{234}$ Conforme aponta Antonio Candido, que acrescenta ainda que esse movimento se manifesta primordialmente no Grupo Festa. Sob a liderança de Tasso da Silveira e Andrade Muricy, é publicada a revista Terra do Sol, e posteriormente a revista que leva o mesmo nome do grupo, divulgando a produção artísticoliterária de seus participantes e disseminando suas propostas estéticas e ideológicas. CANDIDO, Antonio. Literatura e Cultura de 1900 a 1945. In. Literatura e Sociedade - Estudos de teoria e história literária. 8ª̣ed. São Paulo, T.A.Queiroz, 2002.
} 
romance introspectivo de Cornélio Pena (Fronteira) e Lúcio Cardoso (Luz no subsolo, Mãos vazias); social, de Plínio Salgado (O esperado, O cavaleiro de Itararé); dramático, de Octávio de Faria (Mundos mortos, Caminhos da vida), exprimem, seja um inconformismo com o neo-realismo dos modernos, seja com a sua interpretação geralmente radical da sociedade. A poesia de Augusto Frederico Schmidt, neoromântica, a de Jorge de Lima e Murilo Mendes, católica, marcam neste campo, tendências dependentes do Modernismo ${ }^{235}$.

Enquanto Murilo Mendes e Jorge de Lima fazem do catolicismo tema artístico-literário, Cornélio Penna não assume sua filiação religiosa como aspecto de sua identidade intelectual, muito embora transpareça na sua obra $a$ "busca de uma tonalidade espiritualista de tensão e mistério, (que sugere), de um lado, o inefável, de outro, o fervor", nas palavras de Antonio Candido ${ }^{236}$, ao caracterizar os efeitos na literatura do engajamento espiritual e social dos intelectuais católicos.

Seja pelos acontecimentos políticos internacionais (experiência soviética, ascensão do fascismo, crise de 29), e nacionais (crescimento do Partido Comunista, da Ação Integralista Brasileira, a Aliança Nacional Libertadora, e o populismo trabalhista de Getúlio Vargas), seja pelo aumento da consciência política e da própria consciência do subdesenvolvimento do Brasil, sabemos que há na década de 30 uma tomada de posição da intelectualidade que leva à polarização ideológica, fazendo com que as obras se tornassem objeto de reflexão e posicionamento de seus autores. Esse período de engajamento político e social é também um momento de engajamento religioso.

A Igreja conquista então uma posição de relevo na vida nacional, que se reflete na vida cultural do país. As obras, mais ou menos engajadas, de modo mais ou menos explícito, refletiam as preocupações colocadas pelo momento histórico. Ainda nas palavras de Antonio Candido,

Como decorrência do movimento revolucionário e das suas causas, mas também do que acontecia mais ou menos no mesmo sentido na Europa e nos Estados Unidos, houve nos anos 30 uma espécie de convívio íntimo entre a literatura e as ideologias políticas e religiosas. (...) Naquela altura o catolicismo se tornou uma fé renovada, um estado de espírito e uma dimensão estética ${ }^{237}$.

\footnotetext{
235 Ibid. pp.117-126.

${ }^{236}$ CANDIDO, Antonio. "A Revolução de 1930 e a Cultura”. In: A Educação pela noite e outros ensaios. 3ạed. São Paulo, Ática, 2003. p.188.

${ }^{237}$ Ibidem, p. 188.
} 
Desde 1920, com o objetivo de recuperar a influência política perdida com a Proclamação da República e reafirmada pela Constituição de 1891, a Igreja Católica organiza um movimento de reação com o objetivo de criar uma ordem política e social fundamentada nos princípios cristãos, assim como assegurar à instituição o reconhecimento jurídico da sua antiga posição. Tendo instituído o Estado laico, que equiparou o catolicismo às outras expressões religiosas, a educação deixava de ser guiada pelos princípios católicos, e constituía-se em uma das principais preocupações da Igreja.

Na origem deste movimento de reversão está a Carta Pastoral de 1916, do recémnomeado Arcebispo de Olinda, D. Sebastião Leme da Silveira Cintra (1882/1942), em que ao mesmo tempo que analisa a situação conjuntural do catolicismo no Brasil, convoca os fiéis a uma militância condizente com a sua posição de "Nação Católica", de modo a disseminar princípios e restaurar a força política e religiosa da Igreja. Foram muitas as práticas e estratégias surgidas a partir de então, com o objetivo de formar "uma intelligentsia católica, oriunda das fileiras da classe-média alta, capaz de fazer frente ao anticlericalismo, ao ateísmo e à indiferença religiosa das elites republicanas ". ${ }^{238}$

A partir de 1930 o movimento de restauração toma força, com grande impacto na formação de uma intelectualidade católica. Funda-se em 1932 o Instituto Católico de Estudos Superiores, que está na origem da fundação das Universidades Católicas ${ }^{239}$ na década de 40, e os Círculos Operários que atuariam junto aos sindicatos dos trabalhadores. Funda-se ainda a Ação Católica Brasileira (1935), que assimila e articula um grande número de organizações de católicos leigos.

Para fazer frente às aspirações de participarem oficialmente na formação política do país, e tendo fracassado sua participação na Revisão Constitucional de 1926, foi criada ainda a Liga Eleitoral Católica (LEC), organização de caráter suprapartidário, que tinha como

\footnotetext{
${ }^{238}$ cf. DELLA CAVA, Ralph. "Igreja e Estado no Brasil do século XX: sete monografias recentes sobre o catolicismo brasileiro 1916/1964”. Estudos Cebrap, São Paulo, n. 12, 1975. p.12.

239 "Tal projeto, na fase de implantação das Universidades Católicas no Brasil, correspondeu mais aos interesses corporativos imediatos da Igreja, em seu movimento restaurador e, fora dela, aos interesses das camadas médias urbanas em formação, do que aos amplos propósitos culturais e sociais de interesse da sociedade brasileira, como era seu intento manifesto". Cf. CASALI, Alípio. Elite intelectual e restauração da Igreja. Petrópolis: Vozes, 1995.
} 
objetivo mobilizar o eleitorado e apoiar os candidatos ao Congresso Nacional que se alinhassem a seus pontos programáticos ${ }^{240}$.

O envolvimento popular também era necessário para demonstrar a força da Igreja frente às autoridades civis, e é com este intuito que se comemora, com uma mobilização massiva de fiéis, a proclamação de Nossa Senhora da Aparecida como padroeira do Brasil em 1931, e a inauguração do Corcovado, símbolo do poder católico no país ${ }^{241}$.

O projeto de formação de lideranças intelectuais continua nos anos 40 . Além das Universidades Católicas do Rio de Janeiro e do Rio Grande do Sul, cria-se o Movimento Democrata Cristão (1946), liderado por Alceu de Amoroso Lima e Eduardo Frei, que dois anos depois se transformaria no Partido Democrata Cristão.

As questões religiosas estão, portanto, claramente na ordem do dia. São muitas as conversões de intelectuais brasileiros ao catolicismo naquele período, da mesma forma que havia acontecido em alguns países da Europa, como na França, por exemplo. Jackson de Figueiredo, Hamilton Nogueira, Afrânio Peixoto, Augusto Frederico Schmidt, Mário de Alencar, Barreto Filho, Jonathas Serrano, Alceu Amoroso Lima, Gustavo Corção, Murilo Mendes, Jorge de Lima e o próprio Cornélio Penna, são alguns nomes que, juntamente com os já praticantes Ismael Nery, Lucio Cardoso ou Mário Peixoto, só para citar alguns, se ligaram a esse movimento de reação católica.

Como líder laico do movimento e visando a formar uma intelectualidade que difundisse ideias, princípios e valores, e que ocupasse posições importantes na administração do Estado, destaca-se, inicialmente, a figura de Jackson de Figueiredo. Conservador, representante do tradicionalismo católico, defensor da doutrina da ordem, da hierarquia e da autoridade ${ }^{242}$, e avesso ao pluralismo de ideias, é ele quem funda a primeira

\footnotetext{
${ }^{240}$ Com a adesão de grande parte dos constituintes de 1933 ao programa mínimo da Igreja, sabemos que foi promulgada a nova Constituição de 1934 que, embora mantivesse constitucionalmente a separação entre os poderes, incorporou muitas das aspirações eclesiásticas: o reconhecimento do casamento religioso pela lei civil e a proibição do divórcio, a faculdade do ensino religioso nas escolas públicas e o financiamento por parte do Estado de escolas, hospitais, seminários e outras instituições da Igreja designadas como de interesse coletivo. Cf. DELLA CAVA, Ralph. "Igreja e Estado no Brasil do século XX: sete monografias recentes sobre o catolicismo brasileiro 1916/1964". Estudos Cebrap 12.1975, p.15.

241 Ibidem, p. 14.

242 VILLAÇA, Antonio Carlos. O pensamento católico no Brasil. Rio de Janeiro: Zahar, 1975, p.12.
} 
revista de intelectuais católicos no Brasil em 1921, não por acaso denominada A Ordem, e no ano seguinte $o$ Centro Dom Vital, principal centro intelectual, núcleo de debates e difusão do catolicismo brasileiro. Com a morte de Jackson de Figueiredo em 1928, Alceu Amoroso Lima assume a liderança do catolicismo intelectual brasileiro ${ }^{243}$, assim como a direção do Centro e da revista. Embora seguindo a orientação de seu antecessor até fins da década de 30, logo imprime a ambas um caráter mais cultural e menos político, incorporando assuntos de cunho filosófico, literário e histórico ${ }^{244}$, que em muito ajudou a aglutinar parte da elite intelectual $^{245}$, e sugerir a opção cristã como resposta às questões que se colocavam na época, contrapondo-se ao que defendiam como a utopia proposta pela esquerda militante. É neste momento, que autores recém-convertidos, como Murilo Mendes, e outros que então se reaproximavam do catolicismo, como Jorge de Lima, passaram a participar das atividades do Centro.

Alceu Amoroso Lima foi também o responsável pela tradução e divulgação da obra de Jacques Maritain, assim como a de autores católicos como Bernanos ${ }^{246}$, com quem conviveu durante sua estada aqui. A publicação de seus artigos semanais foi fundamental na

\footnotetext{
243 Ibidem, p.113

244 Pode-se dizer que até o fim dos anos 30, Tristão de Athaíde, como era conhecido como crítico literário, orienta-se por essa perspectiva conservadora a que estava ligado, que o leva inclusive a apoiar a participação direta dos católicos na Ação Integralista Brasileira. A partir de então passa a se nortear pelo ideal democrático na linha de Jacques Maritain.
}

${ }^{245}$ Como aponta Fábio de Souza Andrade, a Universidade do Brasil, onde Jorge de Lima foi professor de Literatura Brasileira, foi fundada a partir do projeto pedagógico desenvolvido no Centro Dom Vital.

${ }^{246}$ Sabemos que é grande a influência, no Brasil, do pensamento e das correntes de renovação católica que se desenvolvem na França a partir do século XIX. Em um primeiro momento esta influência foi de caráter bastante conservador, e se caracterizava por uma reação à modernidade. Jackson de Figueiredo foi uma liderança marcada pelo pensamento contrarrevolucionário de Joseph de Maistre e de autores católicos como Charles Maurras, ideólogo da Action Française - movimento político nacionalista e monarquista que se desenvolve nos primeiros anos do século XX na França - que a revista divulgava. Mas em um segundo momento, essa influência vai se orientar num sentido democrata-cristão com a adesão de Alceu Amoroso Lima à filosofia democrática de Jacques Maritain. A partir de 1955, Louis Joseph Lebret e Emmanuel Mounier, associados a outras figuras do catolicismo francês progressista, vão ter um impacto direto sobre o ainda líder Alceu Amoroso Lima e na formação da "chamada esquerda cristã brasileira" do começo dos anos 60 (JEC - Juventude Estudantil Católica; JUC - Juventude Universitária Católica; e AP - Ação Popular MEB's - Movimentos Educacionais de Base) e em sua prática conscientizadora e emancipadora, assim como na Teologia da Libertação, a partir dos anos 70. 
divulgação da obra de autores da Renovação Católica Francesa ${ }^{247}$ como François Mauriac, Paul Claudel, Charles Péguy, Léon Bloy, Joseph Malègue e Julien Green, assim como na do filósofo existencialista Gabriel Marcel ${ }^{248}$. Promoveu debates que atualizavam a posição do pensamento católico internacional, seja com pensadores estrangeiros como o Padre Lebret em 1947, quando da sua primeira viagem ao Brasil, e que foi uma das suas grandes influências ${ }^{249}$, seja com membros da Igreja. É o caso, por exemplo, de palestras realizadas pelo Padre Vaz, profundamente marcado pelo pensamento existencialista ${ }^{250}$, ou pelo Padre Penido que, de volta em 1938, depois de lecionar em diferentes universidades na Europa, publica um artigo sobre o encontro de filósofos do qual havia participado "em 1934 juntamente com, entre outros, Jacques Maritain e Etienne Gilson a respeito da Filosofia cristã”. ${ }^{251}$

O acesso ao debate de questões centrais para a hierarquia católica e o laicato no Brasil colocadas seja pelo Centro Dom Vital, pela Revista A Ordem, pelo Instituto Católico de Estudos Superiores ou pela fundação da Livraria Agir em 1944, que tinha como objetivo ampliar as publicações católicas ${ }^{252}$, atualizavam a intelectualidade na discussão do pensamento católico de então. Sabemos que Cornélio Penna manteve ligações diretas com

\footnotetext{
${ }^{247}$ A Renovação Católica francesa é um movimento literário iniciado nos anos 1910, que reunia escritores católicos cujo projeto era edificar uma estética própria a suas convicções e fé, e que devia servir, segundo a convicção destes, à reconquista religiosa.

${ }^{248}$ VILLAÇA, Antonio Carlos. O pensamento católico no Brasil. Rio de Janeiro: Zahar, 1975, p.121.

${ }^{249}$ Segundo Antonio Carlos Villaça: "Bernanos o afastara da direita. O Maritain do Humanismo Integral, dos Direitos do Homem, de Cristianismo e Democracia, que Alceu traduz e prefacia, o reconciliara com o ideal democrático. (...) O encontro com Lebret veio aproximá-lo da esquerda, em sentido lato." Ibidem, p.115.

${ }^{250}$ A que os católicos, um Gabriel Marcel, um Emmanuel Mounier, um Louis Lavelle, deram a contribuição de seu teocentrismo, da procura do Absoluto, do humanismo de encarnação, do senso profundamente grego do pecado. Ibidem, p.180.

251 Ibidem, p.137.

${ }^{252}$ Alceu Amoroso Lima foi, inclusive um dos fundadores da Livraria Agir [Fonte: Dicionário Histórico Biográfico Brasileiro pós 1930. 2a ed. Rio de Janeiro: Ed. FGV, 2001] "A Era Vargas - 1o tempo - dos anos 20 a 1945". http://cpdoc.fgv.br/producao/dossies/AEraVargas1/biografias/alceu_amoroso_lima [Acesso em: 19/11/2017]
} 
este grupo, tendo em vista sua afinidade com as questões por eles colocadas ${ }^{253}$, sobretudo até seu afastamento da vida pública, no início da década de 40.

Mas se as considerações acima ajudam a situar o contexto em que o autor produziu suas obras e a entender como o debate da intelectualidade católica internacional, sobretudo francesa, se atualizava aqui, é a própria obra que nos leva a levantar hipóteses sobre as relações entre o texto e uma das vertentes do pensamento filosófico de então.

Como dito anteriormente, o autor propõe uma reflexão sobre a história e a constituição das relações sociais no Brasil, colocando a escravidão como um entrave histórico que se reflete tanto no rebaixamento do trabalho quanto na posição e no comportamento dos indivíduos de todas as camadas sociais, ao mesmo tempo em que a representação do mundo objetivo é subjetivada, e o desfecho não coincide com o que se deu historicamente.

O clima de indefinição e mistério que marca o tom da narrativa por um lado lacunar e, por outro, rica em detalhes ao descrever um cotidiano minucioso, e que se estende à forma como o romance é construído, com interrupções, suspensões de pensamentos e de diálogos, é aparentemente bastante paradoxal se pensarmos em termos da lógica de construção do texto, e provoca o leitor a um questionamento mais profundo do sentido da obra. Do mesmo modo, o sofrimento moral dos personagens, um princípio de corrosão que permeia a vida no Grotão, a impressão da iminência constante de algo ameaçador, tudo parece dizer algo mais que o temor de descontinuidade da ordem ali instaurada. Se o sentimento de solidão e desamparo dos moradores, suas dores e dramas, conflitos e culpas, têm uma justificativa social e um fundo histórico, como tentei apontar até aqui, não parecem se limitar a eles. O sofrimento sempre presente e o passado idealizado como feliz contrariam a história de todos os personagens, inclusive a dos senhores, e nesse sentido, o texto parece figurar a existência terrena como um estado de angústia existencial, e o sofrimento como a única possibilidade de redenção. Algumas citações parecem dar a dimensão desta percepção que a leitura provoca:

\footnotetext{
253 De Alceu foi amigo e companheiro quando trabalharam em O Jornal, e depois, enquanto diretor do Instituto de Artes da Universidade do Distrito Federal, da qual Alceu Amoroso Lima foi reitor na segunda metade da década de 30, até que um desentendimento parece ter esfriado o relacionamento que tinham.
} 
E assim tudo continuava em sua aparência habitual, mas havia um princípio de desagregação, de ruína e desmoronamento que todos suspeitavam, e olhavam para o dono da casa como o único capaz de salvá-los, de tornar a fazer reviver e galvanizar aquele grande corpo que lhes parecia agonizante, agitado pelo trabalho subterrâneo da morte. Mas êle próprio andava pelas salas e saía para os campos como um autômato, apesar dos esforços que se tornavam muitas vezes visíveis para manter a mesma atitude de sempre, e todos sentiam que procurava penosamente voltar a ser o Senhor antigo, apoio e guia dos que o rodeavam ${ }^{254}$.

Uma grande mola parecia ter se quebrado na fazenda e todo aquêle enorme organismo, até ali movido com regularidade dos cronômetros, (...) toda aquela grande máquina perdera o seu ritmo e hesitava afrouxada no seu agitar constante. (...) Cada qual sentia no íntimo, ter o Grotão se fendido de alto a baixo, na iminência de ruir, e algum mal estranho corroía suas entranhas... 255

Mas alguma coisa de vazio, alguma coisa que faltava, que não devia ser, o sentimento de uma injustiça indefinível, que pairava no ar e se infiltrava em tudo, as desorientava. Parecera-lhes que o Vigário as libertaria dêsse sentimento incomportável, dessa inquietação dolorosa, dêsse vácuo que lhes oprimia o peito.... ${ }^{256}$.

Embora a narrativa não explicite a relação entre o mal-estar que todos compartilham e a questão da religiosidade, ela parece sugerir que a dor permanente e o sentimento de desamparo com que sobretudo os moradores da casa-grande se confrontam, oprimidos pela fatalidade de seus destinos, fundam-se, para além da questão social, na ausência do sagrado.

Vigora na fazenda uma religião de costumes, mais de exteriorização do que de fé. 0 Comendador, para quem, como muitos então, a religião é apenas "um conjunto de práticas exteriores e rotineiras, destinadas mais a cumprir obrigações tradicionais", 257 parece realizar apenas de modo protocolar sua obrigação de patriarca, com o intuito de regular condutas e servindo, assim, a interesses extra-religiosos.

O padre, que havia deixado a fazenda sem maiores explicações e sem qualquer prestígio junto ao Senhor, que apenas tolerava suas visitas ocasionais, vinha esporadicamente, figurando apenas como confessor no sentido de aliviar as culpas daquelas mulheres. Quando da morte da menina, nem mesmo é recebido pelos pais da criança, o que

\footnotetext{
${ }^{254}$ PENNA, Cornélio. A menina morta. In: Romances Completos. Rio de Janeiro: Nova Aguilar, 1958, pp.823-824.

255 Ibidem, p.1014.

${ }^{256}$ Ibidem, p.779.

${ }^{257}$ Cf. MOTT, Luiz. Cotidiano e vivência religiosa: entre a capela e o calundu. In: SOUZA, Laura de Mello e. (org). História da Vida Privada no Brasil: cotidiano e vida privada na América. 9ạ.reimpr. Vol I São Paulo: Companhia das Letras, 1997, p.175.
} 
indica que não só não se praticavam os ritos do culto, como havia ali apenas uma religiosidade de fachada.

As agregadas, aparentemente muito fervorosas, fazem uso da religião como forma de consolo e refúgio de seu desamparo. Buscam através das orações dissipar seus pensamentos, ou sublimar desejos e culpas. D. Virgínia, a mais pragmática delas, se ressente da falta dos cultos como representação social, tanto em relação aos escravos, como aos vizinhos e parentes.

Celestina, que apesar de condenada pela tuberculose, é curiosamente a única que consegue se libertar da condição de dependente, parece a mais fervorosa entre todas. Professava, no entanto, uma religiosidade de culpas, pecados, expiações e penitências, como traduz o trecho em que temos acesso à consciência da personagem depois do episódio em que, do fundo de uma vala, ela puxa Sinhá-Rola ao tentar sair.

\begin{abstract}
Parecia-Ihe ser o gesto de há pouco a denúncia de seu verdadeiro eu, da profunda maldade que sempre suspeitara existir escondida em seu seio, e agora não sabia como continuar a viver e arrastar consigo aquele monstro sempre de tocaia que a ameaçava, a todo momento pronto a saltar sobre ela. Como agora the pareciam merecidas as injustiças sofridas, as longas humilhações que tinham sido sua vida até ali, privada do apoio de todos os entes amados, e jungida pela sua incapacidade de compreender os outros, de saber-lhes os limites, a uma solidão que desesperava...(...) Mas ao mesmo tempo sentia seus dias se encherem de significação nova, e eram agora marcados por doloroso sêlo que enobrecia a sua humilde paixão tornando-a calvário merecido.(...) Agora sabia... o seu próprio segredo lhe fora revelado... e não estava mais só, precisava lutar e combater o mal conhecido que decerto não era invencível. ${ }^{258}$
\end{abstract}

Quanto às imagens que remetem à história sagrada colocadas no início da narrativa, estas parecem ultrapassar a mera caracterização da crença dos personagens, e querer indicar o sofrimento dos moradores, uma vez que são usadas sempre como termos de comparação com a vida na fazenda. Uma vida que se revela como sofrimento. ${ }^{259}$

O texto, que privilegia, mas não se limita a representar o ponto de vista do núcleo familiar, sugere ainda a prática de rituais africanos junto à escravaria, realizados às ocultas.

\footnotetext{
${ }^{258}$ PENNA, Cornélio. A menina morta. In: Romances Completos. Rio de Janeiro: Nova Aguilar, 1958, p.912.

${ }^{259}$ Como se atesta nas seguintes passagens: “... disse a velha negra, (...) enquanto erguia as mãos, no gesto das Verônicas das procissões, agarradas ao corpinho branco entretecido de prata... p.729; Estava pronto o pequeno esquife (...). Contudo era preciso levá-lo, e o carpinteiro colocou-o sobre os ombros, como se fosse uma cruz...p.736; o Senhor deixava-se conduzir e se não fosse o movimento que lhe imprimia essa marcha, dir-se-ia uma estátua, tal como as das procissões das cidades velhas..." p.745.
} 
Aponta como a religiosidade africana era vista pelos brancos, que temem seu poder e a reduzem a superstição e feitiçaria. Sabemos que os africanos escravizados nunca abandonaram suas tradições, e que os ritos foram assimilados ao culto católico através de práticas sincréticas, conforme representado no romance. É interessante observar como o medo do poder de encantamento dos negros é manipulado por estes, como uma das poucas armas de que dispõem para jogar contra a estrutura. As negras sabiam da suscetibilidade dos brancos e que essas eram uma das poucas formas de resistência de que dispunham para se defender contra seu domínio.

É exemplar o episódio em que Dadade, a africana que tinha sido ama do Comendador, Ihe conta antigas histórias em que mistura memória e imaginação.

Fingindo confundir Celestina com a antiga e poderosa Sinhá, avó do fazendeiro, dando a impressão de ter perdido a lucidez, é com malícia que fala de tempos antigos na fazenda, contrapondo a imagem idealizada de um passado venturoso e de um patriarcalismo harmônico em que todos viviam felizes, e no qual a jovem romântica projetava seus sonhos, à história da escrava sem rosto.

\footnotetext{
[A antiga Sinhá] Fôra uma verdadeira soberana feliz em seu domínio, e sua vida era rio caudaloso que tudo fertilizava em seu caminho tranquilo, pois levava em suas águas majestosas a fecundidade e a paz. Sua fazenda era a Canaã de frutos opimos e sua mesa onde sentavam dezenas de pessoas vergava ao pêso dos produtos da terra trabalhada com alegria. Tudo era abençoado e farto naquela casa, e os filhos de longas barbas curvavam a cabeça diante do pai, beijavam-lhes as mãos como meninos. $\mathrm{O}$ olhar da senhora, seu gesto, eram ordens para todos e um anjo poderoso parecia velar ao seu lado, para que nunca ultrapassasse os limites da prudência e da bondade ${ }^{260}$.
}

A velha escrava parece revelar assim, de forma dissimulada, as relações de tensão e violência que sempre caracterizaram a vida da fazenda, e que a utopia de uma terra fecunda para um povo escolhido é uma felicidade desmascarada pela escravidão que não tem como se cumprir. A escrava sem rosto, imagem da falta de individuação dos cativos assim como da desumanização a que são submetidos, parece simbolizar a ameaça dos negros que, mesmo subservientes, aterrorizam os brancos. Celestina já tinha ouvido as histórias terríveis que se contavam sobre a crueldade dos antigos senhores da fazenda, e logo percebe que não era possível combinar a negra sem rosto e toda aquela opulenta bondade que tudo

260 PENNA, Cornélio. A menina morta. In: Romances Completos. Rio de Janeiro: Nova Aguilar, 1958, pp.862-863. 
transformava em riqueza. Certa de que ouviria da negra uma das histórias da antiga senhora, bela, rica e poderosa, cercada de filhos e escravos, fazendo-a reviver aqueles momentos de modo a sentir possível a felicidade, "teve medo que seus sonhos se desvanecessem, como uma mentira indecifrável, uma inútil e cruel comédia". ${ }^{261}$

Em outra visita à velha escrava, Celestina se apresenta, evitando qualquer possível engano. Dadade pede então à jovem que interceda junto ao senhor para que não mais deixem o bode preto amarrado na varanda em frente ao seu quarto. Ao ter como resposta que já não era permitido deixar os animais entrarem ali, a velha escrava afirma que sabe se tratar mesmo de outra coisa, apavorando a moça com a insinuação da presença de forças demoníacas na fazenda.

Seguindo o procedimento de acumulação já apontado e recorrente na construção do texto, o tema do bode negro retorna. Em determinado momento, ao ouvir gemidos do alpendre que acreditava virem da enfermaria, Carlota se aproxima da senzala e se depara com negros presos no tronco em uma sala com instrumentos que logo percebe serem usados no castigo dos cativos.

\footnotetext{
Parecia-Ihe monstruosa a cena, no entanto muitas vezes vivida em sua memória, e tantas outras contadas pelas mulheres e irmãs daqueles agora diante dela, sem sequer a olharem, se estavam mesmo acordados, na certeza de ser ela alguma aparição infernal, talvez alguém mandado para averiguar se sofriam tanto quanto fora determinado... ${ }^{262}$
}

De volta para casa, passa correndo por uma das colunas que sustentavam a varanda e assusta um animal que estava ali deitado. "Carlota ainda teve tempo de distinguir grande bode preto, inexplicavelmente deixado prisioneiro ali." O texto reafirma assim o que pouco antes a velha Dadade já tinha deixado entrever, e que então se explicita, ou seja, que o sofrimento dos negros se associa à presença do mal rondando a fazenda e seus moradores: Carlota "estava informada de que toda aquela paz, na aparência nascida da ordem e da abundância, todo aquele burburinho fecundo de trabalho, guardavam no fundo a angústia do mal, da incompreensão dos homens, a ameaça sempre presente de sangue derramado" 263 .

\footnotetext{
261 Ibid. p.866.

262 Ibid., p. 1225.

263 Ibid., p.1103.
} 
Desde que chega da Corte, a jovem herdeira se sente desconfortável no ambiente da casa e entre aquelas pessoas que a rodeavam:

Era como se um véu translúcido tivesse se estendido diante dela e a separasse de toda aquela gente em movimento (...) nada fazia sentido e ao olhar em torno de si só via rostos e não almas (...) Tudo imaginado por ela sozinha, no recreio do colégio ou no grande dormitório, quando despertava durante a noite, desaparecera.... ${ }^{264}$

Mas vai cumprindo o papel que lhe cabe, submetida aos desígnios do pai e à mercê das determinações que Ihe são impostas. É aos poucos que começa a perceber a lógica da ordem estabelecida ali.

Certa vez, ao ouvir um dos longos relatos de Libânia sobre a vida da irmã que tentava interceder em favor dos escravos, pedindo a indulgência dos Senhores ou dos empregados da fazenda para com as faltas cometidas, sente-se incomodada.

Passara sua infância longe daqueles pequenos dramas da vida escrava, e nunca tinham chegado até ela os ecos dos lamentos e das queixas dos prêtos. De repente o choque de alguma coisa a despertou e fê-la vir até a realidade, com o estremecimento que lhe causou a recordação da cena por ela presenciada no quadrado, quando João Batista espancara o trintanário... ${ }^{265}$

Outros indícios se somam às histórias rememoradas pela escrava, e assim a jovem herdeira vai aguçando sua percepção da desumanização que dominava todas as relações ali, culminando na sua transformação. A atitude daquele que seria seu futuro marido, "a solicitude inquieta, levada aos últimos limites da submissão" 266 das mucamas da casa, ou as precauções tomadas pelo Comendador antes da sua partida com relação a uma possível revolta da senzala são igualmente perturbadoras.

É emblemática também a cena em que o médico, futuro marido de Celestina, se recusa a aceitar o dinheiro que Carlota lhe oferece como dote da prima por não ter sido ganho com seu esforço - remetendo, como homem livre, à ética do trabalho -, e alegando se tratar de dinheiro sujo de sangue. Surpresa, a jovem herdeira sente-se de início aviltada com a "insinuação infamante a seu pai e a todos os seus, tornados poderosos por aquele ouro que agora lhe escapava das mãos e se espalhava pelo pavimento. Ao mesmo tempo

\footnotetext{
264 PENNA, Cornélio. A menina morta. In: Romances Completos. Rio de Janeiro: Nova Aguilar, 1958,p.1018.

265 Ibidem, p.1188.

266 Ibidem, p.1226.
} 
ressoavam em seus ouvidos gritos de agonia e gemidos sem nome, em côro crescente e cada vez mais alto, a ameaçar entontecê-la completamente" 267 .

A violência e a desumanização a que eram submetidos os escravos parecem constituir a questão central que move Carlota a alforriar os escravos do Grotão, e assim a assumir sua liberdade. A escravidão aparece como uma transgressão moral, ética e se pensarmos em termos religiosos, talvez até mesmo como pecado, do qual ela quer se redimir.

No entanto, a ligação entre a questão social e a religiosa é apontada de modo sutil, como na passagem imediatamente anterior à da aproximação de Carlota da senzala, quando ela se depara com os negros no tronco.

Carlota ao abrir os olhos sentiu a impressão de ter adormecido em um mundo e despertar agora em outro muito diferente, onde não havia paz. (...) A fim de suportar até o fim o monólogo que reboava implacável em sua cabeça, soergueuse para ver se podia encontrar qualquer livro ou rosário que a fizesse fugir daquelas palavras a se tornarem cada vez mais distintas e insistentes em sua mente (...)Tinha de se levantar, era necessário andar e mover-se para poder dominar a agitação que a fizera recuar todos os limites do seu equilíbrio(...)

Quando pronta, abriu a porta do gabinete, e parou surpresa ao ver Joviana e Libânia, envolvidas em cobertas miseráveis, deitadas cada uma em sua esteira, diretamente estendida sobre o soalho. Nunca as vira assim e se as tivesse visto antes, não sentiria o aperto que lhe fez parar a respiração.(...)

Foi para a sala da capela e ajoelhou-se em frente do grande crucifixo posto diante das portas fechadas do oratório, e experimentou dominar-se e rezar. Todavia junto da imagem havia pequena lamparina de globo de cristal vermelho e sua luz dançava, quase esgotada a provisão de azeite, e os clarões de agonia faziam brilhar as gotas de sangue cravejadas de rubis que desciam pelo corpo do Crucificado. Os olhos de Carlota examinaram com espanto a expressão de dor profundamente humana daquele rosto, que parecia viver, nas contrações das angústias da morte próxima. Sentiu naquele drama silencioso entre sombras a acusação e o remorso que a fizeram levantar-se e caminhar, debaixo de sua recriminação envolvente e insustentável ${ }^{268}$.

Misturam-se, portanto, ao lado da opressão da escravidão, questões como culpa e remorso, que remetem à preocupação com questões metafísicas, assim como a da existência contingente e passageira do homem.

\footnotetext{
267 Ibidem, p.1254.

268 PENNA, Cornélio. A menina morta. In: Romances Completos. Rio de Janeiro: Nova Aguilar, 1958, pp. 12231224.
} 
Evidenciam-se ainda aspectos relativos a indagações de ordem existencial, como a impossibilidade de encontro entre os moradores do Grotão, uma estrutura que aprisiona, o mistério que envolve a narrativa, e a preponderância de temas como angústia, tédio, melancolia e morte, que culminam na afirmação de uma liberdade individual, e que nos leva a identificar um diálogo entre a obra e uma das vertentes do pensamento existencialista, o chamado Existencialismo cristão.

Esta aproximação não pretende, no entanto, ler o romance como a demonstração de uma doutrina filosófica, mas apenas apontar para uma afinidade desse pensamento com quem a obra parece dialogar mais de perto, e que nos ajuda a esclarecer um pouco da sua aparente ambiguidade.

O núcleo existencial da obra do autor já foi apontado por Adonias Filho, quando, ao defender a homogeneidade temática dos romances de Cornélio Penna, fala da sua relação em torno da investigação sobre a natureza humana, relacionando-a a Gabriel Marcel, expoente da corrente que se convencionou chamar de Existencialismo cristão, muito embora ele recuse a denominação. Afirma o crítico:

A partir de 'Fronteira', prosseguindo em 'Dois Romances de Nico Horta' e em 'Repouso' até atingir 'A menina morta', a mensagem não evolui horizontalmente. É vertical a sua penetração. Todos os elementos e valores já estão no romance de estréia: o mundo sombrio, o fundo místico, em sangue a conversão da angústia, a catolicidade orientando a inquirição escatológica. Esse núcleo existencial, que se diria um reflexo bíblico - e relacionado, por isso mesmo, ao fluxo que vem de Jó a Gabriel Marcel, - emerge de romance a romance assegurando unidade e coerência à obra de Cornélio Penna ${ }^{269}$.

Adiante o crítico retoma sua proposição, explicitando a aproximação da obra com o teatro do filósofo e dramaturgo francês:

A desesperação, embora flagrante por momentos, não atinge o extremo da "mística do inferno"270 porque não o permitem a fé, a esperança e a caridade. Movendo-se no mesmo núcleo existencial, - a ilustrar-se, por exemplo, com o teatro de Gabriel

\footnotetext{
${ }^{269}$ Adonias Filho. "Os romances da humildade". In: Cornélio Penna Romances Completos, Rio de Janeiro; José Aguilar. 1958. pp. XIII-XIV.

${ }^{270}$ Assim Maritain chamou a filosofia de Sartre. Com relação ao Existencialismo, afirma Alceu Amoroso Lima, "a despeito dessa condição concomitante de teoria, filosofia e literatura (mesmo que seja uma 'mística do inferno', como ao sistema de Sartre chamou Maritain) - podemos distinguir três famílias existencialistas por êsses três traços dominantes. No primeiro, domina a conclusão religiosa; no segundo, a explicação metafísica; no terceiro a intenção estética". In: O Existencialismo e outros mitos do nosso tempo. Obras completas de Alceu Amoroso Lima, vol. XVIII. Rio de Janeiro: Livraria Agir, 1956, p. 51.
} 
Marcel, - reconhecendo embora a solidão e a angústia, vai situar-se de tal modo no plano da consciência que aí configura a vida interior como a grande via para o encontro de Deus ${ }^{271}$.

Cabe observar que, como a de outros filósofos existencialistas, a obra ficcional de Gabriel Marcel, que recusava qualquer sistema da sua doutrina, está em profunda relação com suas reflexões filosóficas. Sobre esta elaboração simbólica, através da qual estes autores transfiguram suas reflexões em ficção, Simone de Beauvoir escreve:

\begin{abstract}
Há duas maneiras de compreender e explicar a realidade metafísica. A primeira é procurar 'esclarecer o seu sentido universal em linguagem abstrata'. A teoria toma forma objetiva e intemporal; o sistema exclui a hipótese de uma outra forma poder ser igualmente real; não são tomadas em conta a subjetividade e a historicidade. A verdade, censitariamente, coincide com a expressão que o sistema lhe fornece. Mas pode-se também incorporar na doutrina o aspecto dramático, concreto e singular de experiência e, por conseqüência, admitir uma espécie de verdade temporal, que não é a verdade em si e abstracta, mas a minha verdade, tal como a tenho vivido. É esta a via existencialista - e por ela se explica que o existencialismo tenha, muitas vezes, preferido exprimir-se por meio da fiç̧ão, tanto no romance como no teatro (G. Marcel, Sartre, Camus). Trata-se, por isso, de apreender o sentido da existência em plena existência, no próprio ato em que ela se realiza. ${ }^{272}$
\end{abstract}

Importante lembrar que o Existencialismo enquanto corrente filosófica compreende uma grande variedade de doutrinas, o que apresenta dificuldades tanto de designação, - daí o nome de Filosofias existencialistas, Filosofia da Existência, Personalismo Existencial, entre outros - como no conjunto de ideias das diferentes vertentes que têm o homem e a existência humana como principal fundamento.

Para alguns pensadores e comentadores ligados à sua vertente cristã, trata-se de uma filosofia difícil de ser definida ${ }^{273}$. Para Alceu Amoroso Lima, por exemplo,

O existencialismo não existe: só existem os existencialistas. (...) O existencialismo é uma experiência irredutível e incomunicável, tanto da parte do sujeito como da parte

\footnotetext{
${ }^{271}$ Adonias Filho. "Os romances da humildade". In: Cornélio Penna Romances Completos, Rio de Janeiro; José Aguilar. 1958. p. XXVIII.

272 Cf. BEAUVOIR, Simone de. Littérature et Métaphysique. In : Temps Modernes, 1 de abril de 1946, p. 11591160. Apud JOLIVET, Régis. As doutrinas existencialistas. Trad. Antonio de Queirós Vasconcelos e Lencastre. Livraria Tavares Martins, Porto, 1961, pp. 5-6.

${ }^{273}$ Emmanuel Mounier propõe, inclusive, uma genealogia da filosofia existencialista que, a partir de Kierkegaard se subdividiria em duas vertentes: o existencialismo ateu que vai de Heidegger a Sartre e o cristão, que está na origem do pensamento de, entre outros, Soloviev, Chestov, Berdiaeff, Martin Buber, Karl Barth, Karl Jaspers, Maurice Blondel e Gabriel Marcel, que representa, para o filósofo, o existencialismo cristão francês mais vivo. Cf. MOUNIER, Emmanuel. Introdução aos existencialismos. Trad. João Bénard da Costa. São Paulo: Duas Cidades, 1963.
} 
do objeto. De modo que não chega nem pode jamais chegar a formular um sistema objetivo e impessoal, uma descrição do universo ou uma estrutura mental que reflita a estrutura do mundo. É um testemunho, é um depoimento pessoal de uma experiência vivida. (...) Não pode, pois, deixar de haver vários tipos de existencialismo, cada qual correspondente a um autor, a uma visão individual, a uma experiência singular. ${ }^{274}$

Para Régis Jolivet, o Existencialismo pode ser definido como "o conjunto de doutrinas segundo as quais a filosofia tem como objetivo a análise e a descrição da existência concreta, considerada como acto de uma liberdade que se constitui afirmando-se e que tem unicamente como gênese ou fundamento esta afirmação de si" 275

Já para Sartre, a dificuldade de se chegar a uma definição do Existencialismo deve-se justamente a essa vertente cristã, o que indica seu reconhecimento como uma linha significativa entre os existencialistas:

[A filosofia existencialista] pode ser definida facilmente. O que torna as coisas complicadas é que existem duas espécies de existencialistas: os primeiros, que são cristãos, e entre os quais eu listaria Jaspers e Gabriel Marcel, de confissão católica; e por outro lado, os existencialistas ateus, entre os quais é preciso colocar Heidegger, e também os existencialistas franceses e eu próprio. O que eles têm em comum é simplesmente o fato de considerarem que a existência precede a essência ou, se preferirem, que é preciso partir da subjetividade.

Como já colocado, Cornélio Penna trata em AMM das relações de domínio e servidão próprias de um regime social determinado, mas também das dificuldades nas relações do eu com o outro que, entre os moradores do Grotão, figura sempre como opressão, impedimento, cerceamento. Por serem relações próprias ao sistema social em que se inserem, por si só não parecem constituir um indício da afinidade acima referida, muito embora o conflito como essência das "relações entre consciências" proposto por Sartre ${ }^{276}$, a desconfiança na possibilidade de comunicação colocada por Kierkegaard ou a

\footnotetext{
274 LIMA, Alceu Amoroso. O Existencialismo e outros mitos do nosso tempo. Rio de Janeiro: Livraria Agir Editora, 1956. Obras completas de Alceu Amoroso Lima. Vol. XVIII, p.50.

275 JOLIVET, Régis. As doutrinas existencialistas. Trad. Antonio de Queirós Vasconcelos e Lencastre. Livraria Tavares Martins, Porto, 1961, p. 21.

276 Para Sartre, A essência das relações entre consciências (...) é o conflito. "L'essence des rapports entre consciences n'est pas le Mitsein, c'est le conflit. SARTRE, L'être et le néant - Essai d'ontologie phénoménologique. Gallimard, 1981. P. 481.
} 
indisponibilidade em relação ao próximo de que trata Marcel $^{277}$, parecem convergir para um mesmo centro de preocupações.

Mas para além dos indícios já apontados, é na trajetória de Carlota, na sua transformação, na angústia que experimenta até que liberta os escravos em um movimento de afirmação de liberdade, que fica mais nítida essa aproximação do texto com o pensamento existencialista. Diferentemente das agregadas, que se limitam ao reconhecimento da servidão a que estão submetidas, e pela sua própria posição social de herdeira da propriedade, ela vai se constituindo como sujeito da sua vida, até dizer não ao projeto que lhe está destinado. Volta-se então para si mesma, convicta da sua ação e do que ela significava.

..., ergueu a cabeça, e todo o seu corpo vibrou com surda e irreprimível alegria e a conviç̧ão inescrutável de que espalhava a morte e a ruína em torno dela, a encheu de sinistro orgulho. Parecia-lhe agora que em seu luto onde se reuniam tantas recordações mortais, lançava também irremediável maldição sobre a terra pisada e varrida por seus crepes. ${ }^{278}$

Em um episódio que tem lugar no dia seguinte à notícia da morte do Comendador, o narrador traduz a percepção da herdeira com relação à reação dos escravos. Para além do medo do desconhecido, em função da mudança de comando na fazenda, os escravos manifestam, mesmo sem "compreenderem bem o que os fazia agir assim", sua solidariedade a ela.

Reunidos no quadrado de volta do eito, ao avistarem Carlota no alpendre, os escravos levantaram-se e aproximaram-se lentamente, detendo-se diante dela em um gesto de respeito e consideração.

Carlota cerrou as pálpebras e entregou-se toda àquela manifestação de amor que a
aprisionava, e tinha certeza de que aquela cena patética era uma vitória sobre muitas
dores e muito sangue. (...) os homens, contagiados pelo pranto e pela emoção das
escravas, tentaram gritar o pedido a Deus para dar longa vida à Sinhá Dona, e não
conseguiram arrancar das gargantas contraídas senão exclamações entrecortadas, de
infantil entonação, que Ihes vinha à mente sem saberem qual o seu verdadeiro
significado:
- Não nos abandone, nossa Sinhazinha, não nos abandone...!
Essas palavras deslizavam sobre ela sem encontrar resistência, sem atingi-la, pois
agora o rosto tapado, ela sentia-se afastada e levada longe dali, estranha àqueles

${ }^{277}$ MARCEL, GABRIEL. Être et Avoir. Paris: Fernand Aubier, p.105.

278 PENNA, Cornélio. A menina morta. In: Romances Completos. Rio de Janeiro: Nova Aguilar, 1958, p.1287. 
semblantes marcados de cicatrizes, ocupada apenas em desafiar o inimigo, o adversário invisível que talvez fosse ela própria. ${ }^{279}$

Reconhecendo, portanto, naqueles homens e mulheres, uma falta de consciência da sua situação e associando-a a certa ingenuidade própria da infância ao se manifestarem de modo tão solidário, ela parece reafirmar seu propósito de resistir à reprodução da ordem dominante.

Enquanto Sartre afirma que é a responsabilidade que cada um tem por si e pelos demais que faz o homem realizar-se como humano, Gabriel Marcel relaciona a solidão do homem na modernidade a um mundo que desumaniza, e em que as relações sociais estão ligadas ao ter e não ao ser. ${ }^{280}$ Importar apenas por seu rendimento, em meio à mais profunda desumanização a que se pode submeter o homem, é exatamente o que vemos ali enquanto representação das relações implicadas pela escravidão.

A grande tentação em que poderemos incorrer é a de sermos levados a "objectivar" os valores, isto é, a fazer deles simples coisas, como moedas que podem passar de mão em mão; a existência esgota-se e volatiliza-se nas suas determinações, transforma-se no ter; a presença muda-se em objeto e em dado; o mistério transforma-se num problema do espírito; o outrem torna-se simples elemento do todo; a pessoa degrada-se em indivíduo... ${ }^{281}$

O movimento de transformação por que passa a jovem herdeira, depois de um longo período de angústia, figura quase que como uma ascese moral, privilegiando o ser e não o ter, conforme distinção feita por G. Marcel.

Para Kierkegaard, considerado um dos precursores do Existencialismo,

Existir é sofrer necessariamente o desespero e a angústia, ligados uma e outro à realidade e à possibilidade de culpa. (...) São muitas as vias que levam ao desespero e nem todo o desespero é fatalmente condição de salvação. O desespero que salva é o que é 'a negação absoluta e definitiva do finito'. ${ }^{282}$

\footnotetext{
${ }^{279}$ Ibidem, p. 1266.

280 “A razão da solidão em que se encontra o homem moderno reside no fato de que o mesmo não vê no próximo senão um Ele, um objeto animado, uma simples natureza, um mecanismo externo de que usa em proveito próprio." Cf. GIORDANI, Mario Curtis. Iniciação ao Existencialismo, p.125.

${ }^{281}$ MARCEL, Gabriel. Du Refus à I'Invocation. pp.192-225. Apud. JOLIVET, Régis. As doutrinas existencialistas. Trad. Antonio de Queirós Vasconcelos e Lencastre. Livraria Tavares Martins, Porto, 1961, pp.373-374

${ }^{281}$ Ibidem, pp.373-374.

282 JOLIVET, Régis. As doutrinas existencialistas. Trad. Antonio de Queirós Vasconcelos e Lencastre. Livraria Tavares Martins, Porto, 1961, p.56.
} 
Importante lembrar que, para as doutrinas existencialistas, cristãs ou não, de Kierkegaard e Gabriel Marcel a Heidegger e Sartre, a existência é marcada por um desespero e angústia que apontam seja para a transcendência de acordo com os primeiros, seja para a morte, a náusea, o nada, conforme os últimos. "Para o pensamento existencialista, o trágico da existência e o sofrimento humano impelem o homem a se transcender, seja elevando-se para Deus, como quer o existencialismo cristão, seja respondendo um apelo para superar seus próprios limites" 283 .

Jaspers e Marcel também defendem que a condição primeira que leva a aceitar a "verdade da existência" é a angústia, ou as "situações-limite", nas palavras do primeiro; situações concretas e contingentes que se apresentam na existência de cada um. A questão da dor, do sofrimento, seria assim o fato revelador para o conhecimento absoluto. "Sentira entretanto, bater dentro de si o coração seguro, capaz de aprisionar seus pensamentos em rígida fórmula, que the daria forças para apoiar-se em si mesma contra o mundo, e mais uma vez reconheceu ter atravessado a porta por onde iria chegar à luz do dia."284

No último capítulo do livro, de modo emblemático, o narrador parece descortinar o diálogo do texto com o pensamento existencialista:

\begin{abstract}
Entretanto, para Carlota, tornada outra mesmo em seu vulto, a vida se tornara um rio de sombra, rápido e profundo, a deslizar invencivelmente por entre margens crepusculares, e ela conseguira fazer de tudo um movimento, um instante eterno. Refugiada no silêncio como a única solidão possível, ela compreendia agora a linguagem de sua casa e dos objetos que a compunham, na impossível reconciliação consigo mesma, na transposição de seu eu diante da eternidade de Deus, protegida por sua vontade que aceitara as suas próprias dimensões. ${ }^{285}$
\end{abstract}

Este permanente devir, este movimento ininterrupto que ele compara às águas dos rios é um ponto importante entre os existencialistas, para quem o homem é um poder ser contínuo, que não se identifica com ele mesmo porque é um projeto em construção, ou em outras palavras, que se constitui no processo de existência.

O homem é sempre mais do que aquilo que de si próprio sabe. Não radica em um estado invariável, antes é um permanente devir; a sua existência não se processa como simples duração, mas através da liberdade, nela se vem a manifestar uma

\footnotetext{
${ }^{283}$ HUISMAN, Denis. História do Existencialismo. Trad. Maria Leonor Loureiro. Bauru: EDUSC, 2001, p.21..

${ }^{284}$ PENNA, Cornélio. A menina morta. In: Romances Completos. Rio de Janeiro: Nova Aguilar, 1958, p.1265.

285 Ibidem, pp.1295-1296.
} 
possibilidade, liberdade pela qual ele decide consoante uma aç̧ão efetiva da sua própria realidade. $\mathrm{O}$ homem não é uma existência em linha fechada que reaparece de geração em geração, nem uma existência transparente, a si mesma visível. (...) 0 que é decisivo no homem é que este, constantemente, se opõe a si próprio. ${ }^{286}$

Daí também a impossibilidade de reconciliação. Por um lado, o movimento que não permite que se permaneça identicamente a si mesmo, por outro o desdobramento implicado na reflexão, entre o sujeito que reflete e o objeto desta reflexão, conforme esclarece Karl Jaspers:

Eu sou um ser capaz de, pela reflexão, se voltar sobre si, um ser cujo ser constitui uma interrogação para si e que, na sua relação a si, se distingue do que é. (...) Quando digo "eu mesmo", desdobro-me, sou simultaneamente um e dois; eu refirome a mim, não sòmente observando-me, mas também agindo sobre mim. (...) Isto equivale a dizer que não há possibilidade alguma de eu poder coincidir comigo em perfeita identidade: pelo mesmo motivo que devo ser activo em relação a mim, eu nunca sou senão possibilidade de um eu-pessoal. O meu acabamento nunca está acabado. $^{287}$

Gabriel Marcel também distingue as duas espécies de reflexão. Para ele, a reflexão primária se exprime em termos de exterioridade, em que sujeito e objeto estão dissociados. Já a reflexão segunda afirmaria uma transcendência em relação ao mundo objetivo, e é da ordem do mistério. No mistério, o sujeito está envolvido e, portanto, deixa de haver uma relação de sujeito e objeto.

[A reflexão primária] só deixa subsistir relações entre coisas, relações impessoais (...) A reflexão segunda é antes de tudo negação e recusa dêsse mundo empobrecido que não é o ser. É negação de uma negação, é uma reconquista. Afirma uma transcendência em relação a esse mundo objetivo. (...) A reflexão primária exercia-se no mundo dos problemas, que é o da objetividade; a reflexão segunda exerce-se no do mistério ${ }^{288}$.

Ao explicitar a diferença entre problema e mistério, ele afirma:

\footnotetext{
286 JASPERS, Karl. A situação espiritual do nosso tempo. Lisboa, Moraes Editores, 1968. pp.226-227.

287 JOLIVET, Régis. As doutrinas existencialistas. Trad. Antonio de Queirós Vasconcelos e Lencastre. Livraria Tavares Martins, Porto, 1961, pp..284-285.
}

${ }^{288}$ A distinção entre problema e mistério está na base do pensamento de Marcel com relação à existência de Deus. Para ele, a existência de Deus é do âmbito do mistério, opondo-se ao conhecimento objetivo. "Deus não existe no sentido em que o pensamento objetivo entende esse termo, isto é, como causa primeira das realidades objetivas. Existe, não no nível do problema, mas no do mistério. É da natureza da fé o não ser objetivamente verificável porque consiste no ato de um sujeito concreto, individual, insubstituível e livre que se acha tão estritamente situado diante de Deus quanto no mundo e, por conseguinte, numa relação única e original com ele". Cf. Garaudy, Roger. Perspectivas do Homem. Rio de Janeiro, Civilização Brasileira, 1965, p.149. 
Um problema é algo com que me deparo, que encontro todo inteiro diante de mim, mas que não posso por isso mesmo abarcar e reduzir, enquanto que o mistério é algo em que eu próprio estou comprometido e que, por conseguinte, só é pensável como uma esfera em que a distinção do em-mim e do ante-mim perde sua significação e seu valor inicial. Quando se trata do mistério, não tenho mais o recuo do espectador, acho-me em causa, e a questão acerca do que é o ser não mais se separa da questão acerca do que sou ${ }^{289}$.

O movimento de desdobramento de Carlota, que se nega a duplicar a imagem da irmã e que completa sua transformação, é bem explicitado no texto, seja quando reage a Celestina, seja quando o narrador traduz suas reflexões, conforme indicam os excertos abaixo:

Compreendo, compreendo a sua estranheza... Eu mesma custei tanto a perceber como estive ausente todos esses anos... Onde estive e que pensei durante todo esse tempo? Foi outra pessoa, vinda de longe, que tomou o seu lugar.... mas, não se lembrava mais de nada, e não podia reconciliar... ${ }^{290}$

Certa manhã quis sacudir dos ombros o peso que neles acumulara sem consciência do que fazia e saiu do quarto, onde se mantinha sempre isolada, à procura do grande ar, do grande espaço que sabia estavam à sua espera lá fora da porta, como amigos fiéis e pacientes. Queria que o sol dissipasse as sombras de seus olhos e iria respirar com o peito libertado da opressão que a fizera viver apenas refugiada em seu espírito. ${ }^{291}$ (...) Mas como um escudo que deslizasse diante dela, mantido e levado por sua vontade renovada, sentiu que caminhava à frente outra Carlota, mais pura e de linhas mais retas e simples, capaz de viver "apenas"292. Com o medo inexplicável que prendera seus movimentos, que limitara e constrangira a vitalidade de seu corpo todo aquele tempo, agora se dissipavam diante da outra os sinais humanos de poder e de dominação, cuja força a tinham mantido prisioneira ${ }^{293}$.

A jovem herdeira acaba por assumir claramente, nos últimos parágrafos, que é ela a verdadeira menina morta. Ela que tinha vindo para a fazenda para substituir a irmã, acaba por realizar a renovação da qual aquela era apenas uma promessa. Compreendendo o sofrimento da mãe com quem se identifica, e aos cuidados de quem passa a se dedicar, ela se recolhe, se impõe uma solidão profunda na luta contra o impessoal, contra o mundo objetivo.

\footnotetext{
289 Ibidem, pp.144-145.

290 PENNA, Cornélio. A menina morta. In: Romances Completos. Rio de Janeiro: Nova Aguilar, 1958, p.1234.

${ }^{291}$ Ibidem, p.1284.

292 Curiosa a questão do viver apenas que ela coloca ao confrontarmos com o excerto de Marcel: "Acima de tudo, precisamos de 'viver' os valores. Ser fiel é (...) manter, através de um esforço, que é uma verdadeira ascese moral, o primado do ser e dos valores que o exprimem". (grifo meu) MARCEL, Gabriel. Du Refus à I'Invocation. pp.192-225. Apud. JOLIVET, Régis. As doutrinas existencialistas. Trad. Antonio de Queirós Vasconcelos e Lencastre. Livraria Tavares Martins, Porto, 1961, pp.373-374)

293 PENNA, Cornélio. A menina morta. In: Romances Completos. Rio de Janeiro: Nova Aguilar, 1958, p.1285.
} 
Ao falar ainda da sua inocência perante Deus, parece reafirmar a hipótese de sentir-se redimida de seus pecados ao destruir aquela estrutura baseada na exploração da mão de obra escrava ${ }^{294}$, e põe em evidência dois temas fundamentais e intimamente relacionados nas filosofias da existência: o da liberdade e o da angústia.

- Eu é que sou a verdadeira menina morta... eu é que sou essa que pesa agora dentro de mim com sua inocência perante Deus... Aquela que morreu e se afastou, arrancando do meu ser o seu sangue para desaparecer na noite, não sei mais quem é... e a mim me foi dada a liberdade, com a sua angústia, que será a minha fôrça!

A liberdade, fundamental na reflexão dos filósofos existencialistas, para quem o homem deve ser entendido como um ser individual e concreto que depende de si mesmo e das escolhas que vier a fazer, confunde-se com a sua subjetividade. Embora limitada pelos fatos que determinam a condição de cada um num mundo objetivamente dado, ela conserva sua singularidade, uma vez que cada um vive subjetivamente essas condições através das histórias pessoais que experimenta e do tempo e do espaço em que está inserido. Mas enquanto para os existencialistas ateus "o homem é liberdade" 295 , para os chamados existencialistas cristãos a liberdade baseia-se na fé e na esperança de alcançar a transcendência. Em outras palavras, ao homem é dado o poder de decidir se afirma ou nega essa transcendência.

\footnotetext{
A liberdade não é um atributo que possuo como uma coisa; na realidade não sou livre mas liberto-me quando guiado por um princípio interior ${ }^{296}$.

O ponto fundamental que define e une o existencialismo como uma posição filosófica, apesar de todas as divergências entre os autores incluídos sob essa denominação, é a ênfase sobre a natureza radical da liberdade humana, e as implicações metafísica e ontológica desta liberdade ${ }^{297}$.
}

294 “- Eu ficarei no Grotão até morrer... Mas não sei se a minha permanência nêle será para a vida ou para a morte do trabalho de nosso pai e de nossos avós...". PENNA, Cornélio. A menina morta. In: Romances Completos. Rio de Janeiro: Nova Aguilar, 1958, p.1276.

295 "O homem está condenado a ser livre. Condenado, pois ele não se criou a si mesmo, e, por outro lado, contudo, é livre, já que, uma vez lançado no mundo, é o responsável por tudo que faz". Sartre, Jean-Paul. $O$ Existencialismo é um humanismo. Editora Vozes, Petrópolis, 2010, p.33.

${ }^{296}$ GIORDANI, Mario Curtis. Iniciação ao Existencialismo. Petrópolis: Vozes, 1997, p. 128.

297 O ponto fundamental que define e une o existencialismo como uma posição filosófica, apesar de todas as divergências entre os autores incluídos sob essa denominação, é a ênfase sobre a natureza radical da liberdade humana, e as implicações metafísica e ontológica desta liberdade. (...) Um existencialista cristão como Gabriel Marcel interpreta o alcance metafísico da liberdade humana em termos de capacidade e responsabilidade de indivíduos de se tornarem "disponíveis" para o mistério da sua participação na criação, em particular, respondendo ao apelo do grande "Tu". Existencialistas ateus (Camus, Sartre, de Beauvoir, Merleau-Ponty), pelo 
Consideradas as diferenças entre eles, no entanto, todos concordam que a liberdade implica angústia. Alceu Amoroso Lima parece sintetizar a posição daqueles ligados à vertente cristã:

A ideia de tomar o mundo como um todo, em relação ao qual a minha acção pudesse ter sentido, vai colidir, por um lado, com o facto de essa ideia ser sempre discutível, e, por outro, com a evidência que resulta da escolha das minhas tarefas e de essas mesmas tarefas serem indefinidamente começos que me arrastam para um processo cujo fim é impossível descobrir. Todavia, eu sinto perfeitamente que sou, como existência possível, mais que aquela individualidade empírica, objectiva e impessoal, que está enquadrada na vida política, científica e econômica; sinto que a existência está em luta contra o mundo tenebroso em que ela se encontra e para além do qual aspira, dentro do seu próprio fracasso, à eternidade do ser. ${ }^{298}$

Kierkegaard, considerado precursor do Existencialismo, chega mesmo a comparar a angústia do espírito à vertigem física, o que nos remete ao episódio do desfalecimento de Carlota nas duas vezes em que ensaia libertar os escravos. Atraída pela possibilidade de romper com aquela realidade pela qual experimenta uma culpa profunda, mas tendo em vista que as consequências das escolhas não são sempre nítidas e que elas implicam em riscos, tem sentimentos paradoxais de desejo e medo. A perda de sentidos que experimenta pode ser entendida pelo temor daquilo que deseja diante das incertezas que dele resultam, ao mesmo tempo em que é movida por ele.

contrário, não baseiam a liberdade na fé e na esperança de alcançar a transcendência; mas ao invés disso, enfatizam a dificuldade de assumir esta liberdade, uma vez que nada pode garantir que nossas tentativas de encontrar sentido para o mundo realmente trarão algo objetivamente presente nele. Em todos os casos a liberdade é o último estágio da capacidade dos seres humanos de se relacionarem com o mundo. (tradução minha)

"The key insight that defines and unites existentialism as a philosophical position, despite all the divergences between the authors included under that denomination, is the emphasis on the radical nature of human freedom, and the metaphysical and ontological imports of that freedom. (...)A Christian existentialist like Gabriel Marcel interprets the metaphysical reach of human freedom in terms of the capacity and responsibility of individuals to make themselves 'available' to the mystery of their participation in creation, in particular by responding to the appeal of the great 'Thou' (see in particular Marcel 1960b). Atheistic existentialists (Camus, Sartre, de Beauvoir, Merleau-Ponty), on the contrary, do not ground freedom in faith and the hope of accessing the transcendent; instead they emphasise the difficulty of assuming that freedom, since nothing can ensure that our attempts at finding meaning in the world will actually yield something objectively present in it. But in all cases freedom is the ultimate ground of human beings' capacity to relate to the world" In: "Existentialist Aesthetics". Stanford Encyclopedia of Philosophy.

<Disponível em: https://plato.stanford.edu/entries/aesthetics-existentialist/> Acesso em: 20171101

298 JOLIVET, Régis. As doutrinas existencialistas: de Kierkegaard a Sartre. Livraria Tavares Martins Porto. 3.ed.1961, p.273. 
Desde que, de facto, o que é dado não é o eu, mas somente a possibilidade do eu, cada um de nós sentir-se-á colocado diante do nada e como que debruçado sobre o vácuo. Vertigem diante do que não é, mas poderá ser pelo uso de uma liberdade que não se experimentou e que não se conhece, a angústia do espírito assemelha-se à vertigem física, naquilo que simultaneamente encerra de temor e de atracção, de simples vislumbre da possibilidade e de terrível encanto ${ }^{299}$.

Diante das ponderações acima, e se considerarmos que a forte subjetividade do romance, assim como o mistério e os enigmas que o caracterizam estão não apenas se contrapondo à tendência neorrealista do Modernismo, mas também afirmando uma estética condizente com a vertente filosófica à qual se vincula, podemos observar que mais uma vez o autor faz uso da ambiguidade como forma de recusar qualquer sistema, resultando na ampliação das possibilidades de leitura da obra.

${ }^{299}$ KIERKEGAARD. Diário, p. 392-393. Apud JOLIVET, Régis. As doutrinas existencialistas. Trad. Antonio de Queirós Vasconcelos e Lencastre. Livraria Tavares Martins, Porto, 1961. p.58. 


\section{Considerações finais:}

Estas considerações finais visam resgatar, em síntese, os principais pontos do percurso aqui descrito, de modo a evidenciar a lógica do todo, bem como os paradoxos anunciados no título desta dissertação.

Ao atentarmos para a caracterização do romance, um dos aspectos que se sobressai é a experimentação. A obra ultrapassa a polarização existente entre o romance social e psicológico que então se colocava e com os quais faz um contraponto, ampliando-a para outras modalidades ficcionais. Para ela convergem diferentes movimentos literários como o Gótico, o Fantástico, o Simbolismo, o Neorrealismo e o Neobarroco. A menina morta estabelece diálogo, também, com diversas vertentes da Literatura brasileira, como a tradição regionalista e o romance fazendeiro, mas sempre recusando qualquer enquadramento crítico. Ao operar com categorias descoladas da crítica, até para não repor as condições de época, Penna cria um gênero híbrido e singular.

O autor faz uso de formas romanescas que retomam antigas formas já suplantadas, e ao mesmo tempo que se contrapõe à modernidade, parece tensionar a relação que a obra estabelece com a tradição, colocando, de modo paradoxal, a experimentação que pressupõe essa modernidade.

Não me parece, portanto, que esse movimento se explique por um simples desejo de retorno ao passado, até porque não há nostalgia naquele universo que ele traz à tona. É um passado impregnado de violência e desumanização, cujas permanências parecem ser um dos fatores de inquietação do presente, o que ajuda a entender o deslocamento temporal que opera. Em entrevista concedida a Ledo Ivo e estampada em O Jornal em maio de $1948^{300}$, pouco antes da publicação de Repouso, ao ser questionado sobre as fazendas de café que, ao contrário de Itabira do Mato Dentro, não eram retratadas na sua obra, Cornélio Penna conta que, ao escrever seu novo romance, havia escrito um capítulo no qual se fazia ouvir a voz "murmurejante" da fazenda de café, com o pranto dos escravos misturando-se à alegria da riqueza dominadora em marcha. Esse capítulo, que remetia a sua herança materna, dizia

${ }^{300}$ Cf. IVO, Ledo. "A vida misteriosa do romancista Cornélio Penna". In: PENNA, Cornélio. Romances Completos. Rio de Janeiro, José Aguilar, 1958, p. LXV. 
o entrevistado, tinha se destacado dos outros. Por isso, acabou por suprimi-lo em seu terceiro romance e guardou-o para incorporá-lo no seu livro seguinte. Importa notar nesse depoimento que a alegria da riqueza apontada pelo escritor, praticamente imperceptível na recriação de A menina morta, dava-se às custas do pranto dos escravos.

O hibridismo da forma do romance pode ser percebido também na matéria, em que se funde o arcaico e o moderno, ou seja, de relações que persistem na modernidade. Seja nas relações do Comendador com seu comissário, na casa de quem se hospeda quando doente, ou na subordinação da justiça ao patriarca, na versão do suicídio do escravo, explicitam-se relações que misturam o pessoal e o comercial, o privado e o público, como padrões herdados da era colonial. Mas é sobretudo na fazenda que se evidencia essa dualidade. O grande empreendimento agrícola, ligado à ordem capitalista, com sua produção voltada para o mercado internacional, confunde-se com uma propriedade feudal, com feições aristocráticas, dominada pelo mando direto, pelo arbítrio e por relações de favor que contrariam os pressupostos de individualidade, direitos e autonomia fundada no trabalho livre. Em outras palavras, podemos pensar que os dados da matéria dão sustentação ao caráter híbrido do romance e enformam sua feição anacrônica.

Por outro lado, a busca de uma expressão singular, assim como a recusa do autor em relação ao meio intelectual, ${ }^{301}$ manifestam uma contrariedade com a modernidade, e, portanto, com as conquistas do Modernismo. Podem ser pensadas mesmo como uma característica antimoderna ou antivanguardista por excelência, ${ }^{302}$ e denotam uma descrença, um pessimismo mesmo, incompatível com as vanguardas ou com o chamado romance social, que apresentam uma perspectiva histórica, e um horizonte de superação.

Do ponto de vista da História, procurei apontar como a inserção das referências históricas se dá de modo diluído, contrastando com a sua precisão, como se, à parte a questão da escravidão e das relações que ela engendra, elas se colocassem de maneira lateral.

301 "Detesto os intelectuais e os literatos. Afastei-me completamente ... e não podia também aprender o modo de contracenar com eles”. (Jornal de Letras, outubro de 1950) Apud. "Apêndice. Introdução geral”. In: PENNA, Cornélio. Romances Completos, Rio de Janeiro: José Aguilar, 1958, p. XLVIII.

302 KAUFMANN, Vincent. "L'arrière-garde vue de I'avant". In: MARX, William (Org.). Les arrière-gardes au XXe siècle. Paris: Quadrige/PUF, 2008. pp. 22-35. 
Poderíamos pensar que esse procedimento se articulava ao debate posto então, em um momento em que a literatura está se posicionando seja pela adesão, seja pelo distanciamento das referências sócio-históricas. Nesse sentido, seríamos levados a pensar que, ao propor tal diluição, o autor estivesse lidando com a especificidade do discurso literário.

No entanto, e paradoxalmente, a História se coloca no centro da narrativa, e Penna parece oferecer uma interpretação do Brasil pelo viés da ficção, ao eleger esse momento fundador como contexto histórico de seu romance maior ${ }^{303}$, no mesmo sentido de Guimarães Rosa, a grande novidade literária representada pelo romance da época, que buscava pela ficção apresentar uma interpretação do país, intervindo na seara dominada pelo pensamento social brasileiro. ${ }^{304}$

Penna propõe uma reflexão das estruturas da sociedade rural brasileira, origem da nossa formação, e estabelece a região do Vale, não apenas pelas afinidades familiares, como pela importância da formação histórica particular da região, cujo núcleo era a Bacia do Rio Paraíba do Sul. Responsável pelo enriquecimento súbito de uma classe senhorial que se integra na ordem econômica mundial e que passa a se espelhar na sociedade europeia, há na região um refinamento dos hábitos, a transformação das moradias e a "auto-atribuição" de nobreza aos proprietários, reforçada pelos títulos que recebiam.

A par disso, e contradizendo a hipótese da defesa da especificidade da Literatura, o autor levanta a questão de gênero vinculada à questão de classe social, remetendo ao debate sobre a intervenção do discurso literário em outros campos de conhecimento.

A representação feminina ocupa posição de destaque, uma vez que é sob essa perspectiva que é construído o romance. Ele evidencia o vazio em que vivem essas personagens submetidas social, econômica e moralmente em uma sociedade pautada por valores masculinos. No entanto, são elas que condensam ao mesmo tempo as estruturas de dominação e de resistência.

\footnotetext{
${ }^{303}$ Cf. sugerido por Vagner Camilo.

304 RONCARI, Luiz. “Introdução”. In: O amor e o poder. 1a reimpressão. São Paulo: UNESP, 2004, pp.13-24.
} 
No mesmo sentido, e também de modo paradoxal, são as negras, a quem é interditada a palavra, as que transmitem à Carlota as poucas informações que temos, indicando que pela sua "meia-língua" são as verdadeiras guardiãs da memória dos tempos.

Com relação ao acúmulo de pormenores que compõem a narrativa, nas descrições minuciosas e no relato fiel da vida em um latifúndio cafeeiro na segunda metade do século XIX, eles não apenas contrariam o "embaçamento" dos acontecimentos históricos mas, sobretudo, são incongruentes com os silêncios e as interrupções do plano narrativo. $A$ menina morta parece dialogar com o romance neorrealista dos anos 1930, indicando que o acúmulo de pormenores pouco vale para uma compreensão efetiva, e desvalorizando a experiência, de certo modo contingente, daqueles personagens.

Ao omitir informações ao leitor, o narrador onisciente contradiz a sua onisciência e coloca o leitor na mesma posição subjugada dos outros habitantes, como já apontado por Vecchi: "o leitor desse romance lento e estagnado se encontra imerso numa experiência comum com os outros habitantes da Casa Grande, ou seja, a interdição sistemática a todo o tipo de informação" 305 . É o crítico quem aponta ainda o paradoxo do "excesso de escrita em oposição à exiguidade da ação" ${ }^{306}$ que marca o romance.

Há uma motivação social explícita na obra, que não se dá apenas pela escolha da matéria narrada, mas pela fidelidade na caracterização dos diferentes grupos sociais e do painel das relações que estabelecem entre si, determinantes da condição dos sujeitos. No entanto, o objeto da narração parece ser como as tensões se interiorizam nos personagens, e como eles reagem a elas. A consciência de um tempo circular que apenas se atualiza, aprisiona e justifica a angústia dos personagens, oprimidos pela fatalidade de seus destinos. Não há na obra o sentido de transitoriedade associado ao moderno. Toda a estrutura parece imune a qualquer mudança, cabendo aos protagonistas apenas reatualizar e aceitar seu sofrimento.

As imagens do texto, depois de alforriados os escravos da fazenda, remetem a morte e destruição.

\footnotetext{
${ }^{305}$ VECCHI, Roberto. “O espaço mudo da exceção: a revocalização do subalterno pela escrita literária”. In: CAIRO, Luiz Roberto et al. (Falta o título e não consta na bibliografia) Assis: UNESP, 2008. pp.215-230.

306 Ibidem, p.225.
} 
Com esforço conseguiu andar e seus vestidos varreram o caminho, como um grande manto que se arrastasse pelo chão, despedaçando-se nas pontas das pedras e nos espinhos das moitas, e deixavam atrás de si farrapos negros, salpicados de pequeninas frutas selvagens e rubras semelhantes a gotas de sangue...

Entretanto, (...) a conviç̧ão inescrutável de que espalhava a morte e a ruína ${ }^{307} \mathrm{em}$ torno dela, a encheu de sinistro orgulho.

É como se o manto negro que cobria a propriedade, fosse se desfazendo pelo caminho deixando para trás seus farrapos salpicados de sangue, flores mortas, e esmagadas. No entanto, e apesar do seu esforço, a fazenda ressurge dessa ruína, dessa impossibilidade, e retoma seu antigo ritmo. A ruína não aponta, portanto, para a transitoriedade a que o conceito remete e assim para a história, mas para a permanência, revelando-se como resíduo capaz de provocar uma inquietação do passado no presente.

Esse movimento que parece se colocar fora da história, assim como a solidão que a personagem se impõe, estão na origem do Existencialismo cristão, mais especificamente em Kierkegaard, para quem o recolhimento é condição do aprofundamento em si. Para o filósofo dinamarquês,

São muitas as vias que levam ao desespero e nem todo o desespero é fatalmente condição de salvação. O desespero que salva é o que é a negação absoluta e definitiva do finito. É impossível escapar ao desespero. (...) o desespero desarraiga o homem de si mesmo, como ser finito, e entrega-o a si mesmo naquilo que tem de eterno." 308

Gabriel Marcel, que retoma a proposição, acrescenta ainda que a reflexão profunda se impõe na luta contra o impessoal, na passagem "do Ter ao Ser", do problema em mistério.

Portanto, marcado por forte subjetividade e negatividade, $A$ menina morta não aponta para superações. Como ressaltado anteriormente, o sofrimento parece figurar como única possibilidade de redenção, e a morte como triunfo sobre a vida. Daí a hipótese que a questão que se coloca não é apenas social, mas de fundo existencial e religioso.

O texto transparece, mesmo sem qualquer afirmação de caráter mais dogmático, uma religiosidade que não nega a história, nem uma história que nega a transcendência, como se a existência fosse regida por leis que se situam fora da história, mas articuladas a ela, coincidindo com a perspectiva do Existencialismo cristão proposto por Gabriel Marcel,

\footnotetext{
${ }^{307}$ Grifo meu

308 JOLIVET, Régis. As doutrinas existencialistas: De Kierkegaard a Sartre. Porto: Tavares Martins, 1961, p.56
} 
para quem o homem se descobre engajado em um mundo, ao mesmo tempo que limitado por ele.

A vida como sofrimento, essa perspectiva desencantada, melancólica, que estabelece uma relação particular com a morte, ou seja, da morte como libertação, traduz ao mesmo tempo uma posição religiosa, e uma angústia existencial para além das questões do tempo.

Sabemos que o próprio Existencialismo, com quem Penna apresenta grande afinidade na sua vertente cristã, nasce de um momento de perplexidade, no início do século XX. A situação em que ele floresce, colocando em cena os pressupostos desenvolvidos por Kierkegaard ainda em meados do século anterior, exigia novas respostas aos problemas que então se colocavam, e obrigavam à renovação de antigas filosofias. Para os existencialistas, o primado da objetividade havia subordinado o subjetivo, e se traduzia na situação de impotência dos homens. As principais obras ligadas a essa corrente, embora de modos diversos, conjugam o filosófico e o literário, e traduzem essa consciência de abandono, de solidão e de impotência do homem contemporâneo. O momento histórico, a barbárie da guerra tinha colocado em cheque a racionalidade, a investigação científica e o sentido do progresso. ${ }^{309}$

A relação íntima do enredo com uma doutrina filosófica ajuda, portanto, a entender a feição do romance, com suas ambiguidades e paradoxos, e o coloca como um texto de alcance mais amplo, que vai para além dos fatos narrados. Poderíamos pensar mesmo que as ambiguidades e paradoxos constituem o princípio que o estrutura, e talvez possam ser entendidos como extensão das ambiguidades históricas e das dinâmicas da vida social no país, tendo em vista a particularidade do nosso processo de modernização, estruturado sobre a desigualdade e o atraso.

\footnotetext{
${ }^{309}$ Para Garaudy, em quem se baseiam esses pressupostos, "É significativo que o Existencialismo tenha conhecido seu maior esplendor na Alemanha após a derrota de 1918 e na França após a de 1940: a derrocada das estruturas sociais, políticas, nacionais, espirituais que davam até então uma consistência à vida individual, conduz o homem a tomar consciência da sua responsabilidade pessoal, de sua liberdade, num mundo em ruínas". GARAUDY, Roger. Perspectivas do Homem. Existencialismo, Pensamento Católico, Marxismo.2ª. ed. Rio de Janeiro: Civilização Brasileira, 1966, p.9
} 
Se tomarmos de empréstimo as palavras de Antonio Candido que se referem, no entanto, a outro romance e em outro contexto, poderíamos dizer que "seu desfecho é um caso paradoxal de triunfo na derrota, de plenitude extraída da privação" ${ }^{310}$.

A obra reflete, portanto, a negatividade e a descrença que se justificam por essa dimensão filosófico-religiosa, e que talvez possam nos ajudar a esclarecer a própria escrita arcaizante de $A$ menina morta que, se não por outro motivo, enobrece o tema.

\footnotetext{
${ }^{310}$ A formulação de Antonio Candido refere-se ao romance de Dino Buzzatti, Deserto dos Tártaros. Guardadas as enormes diferenças que os caracterizam, tanto de fatura como de sentido da obra, podemos pensar em algumas afinidades com o texto de Penna. A iminência de algo que ameaça mas não se realiza, e que sugere um vazio existencial, assim como a de uma espera que dê sentido à vida e que parece se realizar na morte. In: CANDIDO, Antonio. "Quatro esperas". O discurso e a cidade. 3a ed. São Paulo, Rio de Janeiro: Duas Cidades, Ouro sobre Azul, 2004, pp.145-159.
} 


\section{REFERÊNCIAS BIBLIOGRÁFICAS}

\section{Do Autor:}

PENNA, Cornélio. A menina morta; Fronteira; Dois Romances de Nico Horta; Repouso. In: Romances Completos. Rio de Janeiro: Nova Aguilar, 1958.

PENNA, Cornélio. A menina morta. Lisboa: Cotovia, 2006 (Curso Breve de Literatura Brasileira, Vol. 9).

. "As cartas de Ulla” [online]. In: Correio da Manhã, Biblioteca Nacional. Dados para

localização: 1957 edição $19623 \quad$ p.9 Disponível em: <http://memoria.bn.br/DocReader/docreader.aspx?bib=089842_06\&pasta=ano\%20195\&pe sq=Cornelio\%20Pena > Acesso: 05/10/2017.

\section{Sobre o autor:}

ANDRADE, Mário de. "Romances de um antiquário". In: $\mathbf{O}$ empalhador de passarinho. Belo Horizonte: Itatiaia, 2002.

BUENO, Luís. Uma história do romance de 30. São Paulo: Edusp; Campinas: Editora Unicamp, 2006.

CUNHA, Fausto. "Forma e criação em Cornélio Penna". In: Situações da ficção brasileira. Rio de Janeiro: Paz e Terra, 1970. (Coleção Estudos sobre o Brasil e a América Latina, vol. 16)

EULÁLIO, Alexandre. "Os dois mundos de Cornélio Penna". In: WALDMANN, Berta; DANTAS, Luiz (org.). Escritos. Campinas: Unicamp, 1992. pp.443-463.

FILHO, Adonias. "Os romances da humildade". In: Cornélio Penna - Romances Completos. Rio de Janeiro: José Aguilar, 1958.

HERBOLD, Hildegard. O sagrado e o profano na literatura intimista dos anos 1930/1940 no Brasil: o exemplo de Lúcio Cardoso e Cornélio Penna. Dissertação de mestrado. São Paulo: FFLCH - USP, 1993. 
IVO, Ledo. "A Vida Misteriosa do Romancista Cornélio Penna". In: Cornélio Penna: Romances Completos. Rio de Janeiro: Nova Aguilar, 1958.

LIMA, Luiz Costa. "Sob as trevas da melancolia: o patriarcado em A menina morta". In: A Aguarrás do Tempo: Estudos sobre a narrativa. Rio de Janeiro: Rocco, 1989.

. O Romance em Cornélio Penna. 2a edição revista e modificada. Belo Horizonte: Editora UFMG, 2005.

A perversão do trapezista: o romance em Cornélio Penna. Rio de Janeiro: Imago; Secretaria da Cultura, Ciência e Tecnologia, 1976.

LUCENA-GUERRA, Lúcia Pereira de. "A menina morta de Penna: a topografia da escritura de um grande e desconhecido romance da Literatura Brasileira" [online]. Disponível em: <www.sitemason.vanderbilt.edu./files > Acesso: 23 de junho de 2017

MESSEDER, Luciana. "Por uma contextualização sócio-histórica de $A$ menina morta, de Cornélio Penna" [online] Dissertação de mestrado. Rio de Janeiro: Faculdade de Letras-UERJ, 2006. <Disponível em: http://livros01.livrosgratis.com.br/cp150784.pdf> Acesso: $21 / 11 / 2017$.

MIRANDA, Wander Melo. A menina morta: a insuportável comédia. Dissertação de mestrado. Belo Horizonte: Faculdade de Letras - UFMG, 1979.

MOURÃO, Rui. "A ficção modernista de Minas". In: 0 modernismo. 2a ed. São Paulo: Perspectiva, 2002.

OSAKABE, Haquira. "O crime como redenção: uma aproximação aos primeiros romances católicos de 30". In: Formas e mediações do trágico moderno: uma leitura do Brasil. São Paulo: Editora Unimarco, 2004.

RODRIGUES, André Luís. Fraturas no olhar: Realidade e representação em Cornélio Penna. Tese de Doutorado. São Paulo: FFLCH - USP, 2006.

RUFINONI, Simone Rossinetti. Favor e Melancolia - Uma leitura de A menina morta, de Cornelio Penna. Tese de Doutorado. São Paulo: Faculdade de Filosofia, Letras e Ciências Humanas, Universidade de São Paulo, 2005.

. "Realismo e introspeç̧ão no romance de Cornélio Penna". In: Literatura e Sociedade: Departamento de Teoria Literária e Literatura Comparada da USP, São Paulo, n. 14(2), p. 121, 2010.

SAMARA, Eni de Mesquita. "O romance gótico e a obra de Cornélio Penna". In: Revista Brasileira de Literatura Comparada, nำ14, 2009. 
SANTILLI, Maria Aparecida. "Angústia e fantástico no romance de Cornélio Penna". In: Revista de Letras. Publicação anual da Faculdade de Filosofia Ciências e Letras de Assis, Assis, no 5, 1964.

SANTOS, Josalba Fabiana dos. "Monstros e duplos em A menina morta". In: JEHA, Julio (Org.) Monstros e monstruosidades na literatura. Belo Horizonte: Editora UFMG, 2007.

. "O Romance Gótico e a Obra de Cornélio Penna" [online]. XI Congresso Internacional da ABRALIC. 13 a 17 de julho de 2008. p.6. Disponível em: http://www.abralic.org.br/eventos/cong2008/AnaisOnline/simposios/pdf/077/JOSALBA SA NTOS.pdf Acesso: 23/09/2017.

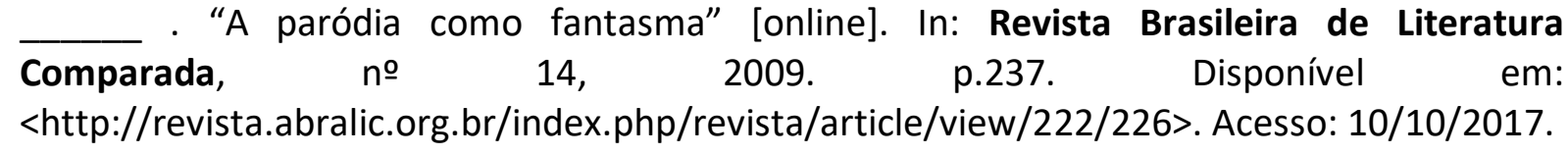

Fronteiras da nação em Cornélio Penna. Tese de doutorado. Belo Horizonte: Faculdade de Letras - UFMG, 2004.

SCHINCARIOL, Marcelo Tadeu. Em busca da alma de Itabira: uma leitura de Cornélio Penna. Dissertação de Mestrado. Campinas: Instituto de Estudos da Linguagem da Universidade Estadual de Campinas, 2001.

A arte complexa de ser infeliz: a ficção de Cornélio Penna. Tese de Doutorado. Campinas: Instituto de Estudos da Linguagem da Universidade Estadual de Campinas, 2009

SCHLAFMAN, Leo. "A revelação de Cornélio Penna". In: A verdade e a mentira: novos caminhos para literatura. Rio de Janeiro: Civilização Brasileira, 1998.

SCHMIDT, Augusto Frederico. "O Anjo entre os escravos". In: Cornelio Penna - Romances Completos. Rio de Janeiro: Nova Aguilar, 1958.

. "Nota preliminar". In: A menina morta. In: Romances Completos. Rio de Janeiro: Nova Aguilar, 1958, p.724.

SIMÕES, Irene Jeanete Gilberto. Oficina de Artista - A linguagem dos romances de Cornelio Penna. Tese de doutorado. São Paulo: FFLCH-USP, 1990.

VECCHI, Roberto. "Autópsia da casa-grande (A que vulgarmente chamamos Brasil)". In: PENNA, Cornélio. A menina morta. Coleção Breve de Literatura Brasileira vol.9. Lisboa: Cotovia, 2006, pp.531-556.

"O que resta do trágico - Uma abordagem no limiar da modernidade cultural brasileira" In: Formas e mediações do trágico moderno: uma leitura do Brasil. São Paulo: Editora Unimarco, 2004. 
. "O espaço mudo da exceção: a revocalização do subalterno pela escrita literária". In: CAIRO, Luiz Roberto et al. (Falta o título e não consta na bibliografia) Assis: UNESP, 2008. pp.215-230.

Geral:

ALENCAR, José de. $\mathbf{O}$ guarani. 2a ed. São Paulo: Ateliê Editorial, 2000.

0 tronco do ipê. 12a ed. São Paulo: Melhoramentos, 1965.

Til. 2a ed. 2a reimpr. São Paulo: Ática, 2004. (Coleção Bom Livro)

ALENCASTRO, Luiz Felipe de. (Org.). História da vida privada no Brasil: Império - A corte e a modernidade nacional. São Paulo: Companhia das Letras, 1997. (Coleção História da Vida Privada no Brasil, Volume 2).

ALMEIDA, José Maurício Gomes de. A tradição regionalista no romance brasileiro: 1857 1945. Rio de Janeiro: Achiamé, 1981.

ALMEIDA, José Tadeu. "Transição política e gestão macroeconômica no Brasil Império: Os gabinetes de Conciliação - 1853/1862". Trabalho apresentado na III Conferência Internacional em História Econômica e V Encontro de pós-graduação em História Econômica. Brasília, 2010.

ANDERSON, Perry. "Modernidade e Revolução". Trad. Maria Lúcia Montes. In: Novos Estudos Cebrap, São Paulo, no 14, mar-abr 1984.

ANDRADE, Mário de. "A psicologia em ação". In: O empalhador de passarinho. Belo Horizonte: Editora Itatiaia, 2002.

ANDRADE, Mário de. A psicologia em análise. In: 0 empalhador de passarinho. Belo Horizonte: Editora Itatiaia, 2002.

ANDRADE, Mário de. Aspectos da literatura brasileira. Belo Horizonte: Editora Itatiaia, 2002.

ARAÚJO, Ricardo Benzaquen de. Guerra e Paz: Casa-grande \& senzala e a obra de Gilberto Freyre nos anos 30. São Paulo: Editora 34, 1994.

ARISTÓTELES. Poética. Trad. Eudoro de Sousa. Lisboa: Imprensa Nacional; F.C.S.H. da Universidade Nova de Lisboa, [s.d.], pp.115-116.

AUERBACH, Erich. "Na mansão de La Mole" e "A meia marrom". In: Mimesis: A representação da realidade na literatura ocidental. 4a ed. 2 a reimpr. São Paulo: Perspectiva, 2002. 
BAPTISTA, Maria Manuel. Ekphrasis e (des)ocultação da verdade - Uma reflexão a partir da filosofia heideggeriana [online]. In: Caminhos de Cultura em Portugal: Homenagem ao Professor Doutor Norberto Cunha. Fernando Augusto Machado, et al. (Org.). Portugal, Ribeirão: Edições Húmus, 2010, pp.337-343. <mariamanuelbaptista.com/pdf/Ekphrasis.pdf> Acesso: 28/08/17.

BARBOSA, Paula Maciel. 0 idílio degradado: um estudo do romance Til de José de Alencar. Tese de Doutorado. São Paulo: FFLCH, Universidade de São Paulo, 2012, pp.194 - 202.

BARTHES, Roland. "O efeito de real". In: O rumor da língua. Trad. Mário Laranjeira. São Paulo: Brasiliense, 1988.

BINZER, Ina von. Os meus romanos: alegrias e tristezas de uma educadora alemã. São Paulo: Ed. Paz e Terra, 6a ed., 1994.

BOSI, Alfredo. História concisa da literatura brasileira. 39ạ ed. São Paulo: Cultrix, 2001.

"Um mito sacrificial: o indianismo de Alencar" e "A escravidão entre dois liberalismos". In: Dialética da colonização. 4a ed. 5a reimpr. São Paulo: Companhia das Letras, 2006.

BRECHT, Bertolt. "Amplitude e variedade do modo de escrever realista" [online]. In: Estudos Avançados. São Paulo, v. 12, n. 34, p. 267-276, dec. 1998 . Disponível em <http://www.scielo.br/scielo.php?script=sci_arttext\&pid=S0103-40141998000300024 >. Acesso: 24/03/2017.

BURGER, Peter. "O declínio da era moderna". Trad. Heloísa Jahn. In: Novos Estudos CEBRAP, no 20. São Paulo, março de 1988, pp. 81-95.

CAMILO, Vagner. A modernidade entre tapumes: da lírica social à conversão neoclássica na poesia brasileira moderna. São Paulo; USP (2017).

CAMPOS, Haroldo de. "A escritura mefistotélica". In: Deus e o diabo no Fausto de Goethe. São Paulo: Perspectiva, 2005.

CANABRAVA, Alice P. "A grande lavoura". In: HOLANDA, Sérgio Buarque de (Dir.). O Brasil Monárquico: Declínio e Queda do Império. Tomo II. Volume 4. História Geral da Civilização Brasileira. São Paulo: Difusão Européia do Livro, 1971.

CANDIDO Antonio. "Literatura e subdesenvolvimento" e "A Revolução de 1930 e a Cultura. In: A educação pela noite e outros ensaios. 3a ed. 2a reimpr. São Paulo: Ática, 2003, pp.140162; 181-215.

"Literatura e Cultura de 1900 a 1945". In: Literatura e Sociedade: Estudos de teoria e história literária. 8.ed. São Paulo, T.A.Queiroz, 2002.

Janeiro:

"Os três Alencares". In: Formação da Literatura Brasileira. Belo Horizonte/Rio de 
Itatiaia, 2000.

"Realidade e realismo (via Marcel Proust)". In: Recortes. 1a reimpr. São Paulo: Companhia das Letras, 1996.

Press, (s.d.)

"The brazilian family". In: Brazil: portrait of half a continent. New York: The Dryden

. "Quatro esperas". In: O discurso e a cidade. 3a.. Ed. São Paulo e Rio de Janeiro: Duas Cidades/ Ouro sobre azul, 2004. pp.131-172.

CANDIDO, Antonio et. al. A personagem de ficção. 10.ed. São Paulo: Perspectiva, 2002.

CANDIDO, Antonio; CASTELO, J. Aderaldo. "Cornélio Penna". In: Presença da literatura brasileira. vol.III. 3a ed. São Paulo: Difusão Européia do Livro, 1968.

CASTELLO, José Aderaldo. A literatura brasileira - Origens e unidade. Vol. II. São Paulo, EDUSP, 2004, pp.323-375.

CARVALHO, José Murilo de. A construção da ordem: a elite política imperial. 5ạ ed. Rio de Janeiro: Civilização Brasileira, 2010.

CASALI, Alípio. Elite intelectual e restauração da Igreja. Petrópolis: Vozes, 1995.

CASTELLO, José Aderaldo. A literatura brasileira: Origens e unidade. vol.II. 1a ed. 1a reimpr. São Paulo: EDUSP, 2004, pp. 323-375.

CEIA, Carlos. E-Dicionário de Termos Literários [online], coord. De Carlos Ceia. Disponível em <http://www.edtl.com.pt $\geq$. Acesso: 13/07/2017.

COMPAGNON, Antoine. "Os modernos em Liberdade". In: Os Antimodernos - De Joseph de Maistre a Roland Barthes.Trad. Laura Taddei Brandini.Belo Horizonte: UFMG, 2011, pp.1147.

CORRÊA, Mariza ... et al. "Repensando a família patriarcal brasileira". In: Colcha de Retalhos: Estudos sobre a família no Brasil. Campinas: Editora da Unicamp, 1993.

COSTA, Emília Viotti da. Da Monarquia à Repúbilca: momentos decisivos. $8^{a}$ ed.rev. e ampliada, São Paulo: UNESP, 2007.

Da senzala à colônia. 4ae ed. 5ạ. Reimpressão. São Paulo: Ed. UNESP, 1998.

D’ELBOUX, Roseli Maria Martins. “Uma promenade nos trópicos: os barões do café sob as palmeiras imperiais, entre o Rio de Janeiro e São Paulo". In: Anais do Museu Paulista, v.14 n.2. jul-dez, 2006.

DELLA CAVA, Ralph. "Igreja e Estado no Brasil do século XX: Sete monografias recentes sobre o catolicismo brasileiro 1916/1964". Estudos Cebrap, São Paulo, n. 12, 1975, pp. 6-52. 
DIAS, Maria Odila Leite da Silva. Quotidiano e poder em São Paulo no século XIX. 2a ed. São Paulo: Brasiliense, 1995.

Dicionário Histórico Biográfico Brasileiro pós 1930. 2a ed. Rio de Janeiro: Ed. FGV, 2001] "A Era Vargas - 10 tempo - dos anos 20 a 1945". http://cpdoc.fgv.br/producao/dossies/AEraVargas1/biografias/alceu_amoroso_lima [consultado em 201711 19]

DIMAS, Antonio. Espaço e romance. 3ạ ed. São Paulo: Ática, 1994. (Princípios)

ÉLIS, Bernardo. "Tendências Regionalistas no Modernismo". In: ÁVILA, AFFONSO. O Modernismo. 2ª. Ed. São Paulo: Perspectiva, 2002. pp.87-102

FAORO, Raimundo. Machado de Assis: A pirâmide e o trapézio. 4aed. rev, 1a reimpressão. São Paulo: Globo, pp.13-66.

FERNANDES, Florestan. A revolução burguesa no Brasil: ensaio de interpretação sociológica. 5a ed. 4a reimpr. Pref. José de Souza Martins. São Paulo: Globo, 2010.

FRANCO, Maria Sylvia de Carvalho. Homens Livres na Ordem Escravocrata. São Paulo: UNESP, 1997.

FREUD, Sigmund. "Luto e Melancolia". Trad. Marilene Carone. In: Novos Estudos CEBRAP, n. 32, São Paulo, 1992.

FREYRE, Gilberto. Casa-grande e senzala e Sobrados e mucambos. Rio de Janeiro: Nova Aguilar, 2002. (Intérpretes do Brasil, v.2. 2.ed.)

FRIEDMAN, Norman. "O ponto de vista da ficção: o desenvolvimento de um conceito crítico". Trad. Fábio Fonseca de Melo. REVISTA USP. São Paulo, n.53. mar/mai 2002. p. 166182.

GARAUDY, Roger. Perspectivas do Homem - Existencialismo, Pensamento Católico, Marxismo. 2a . Ed. Trad. Reinaldo Alves Ávila. Rio de Janeiro: Civilização Brasileira, 1966.

GIORDANI, Curtis Mário. Iniciação ao Existencialismo. Petrópolis: Vozes, 1997.

O Existencialismo à luz da Filosofia Cristã. Aparecida: Idéias \& Letras, 2009.

GOMES, Heloísa Toller. O poder rural na ficção. São Paulo: Ática, 1981. (Ensaios)

HANSEN, João Adolfo. "Categorias Epidíticas da ekphrasis". In: Revista USP, São Paulo, n.71. p.85-105, set/nov 2006.

HOLANDA, Heloísa Buarque. "Os estudos sobre mulher e literatura no Brasil: uma primeira abordagem." [online] In: Seminário "Estudos sobre Mulher no Brasil - Avaliação e Perspectivas" promovido pela Fundação Carlos Chagas de 27 a 29 de novembro de 1990. 
Disponível em: <http://www.heloisabuarquedehollanda.com.br/os-estudos-sobre-mulher-eliteratura-no-brasil-uma-primeira-abordagem-9/> Acesso: 08/05/2017.

HOLANDA, Sérgio Buarque de. (Dir.) O Brasil monárquico. Declínio e queda do Império. Tomo II vol. 6. História geral da civilização brasileira. Rio de Janeiro: Bertrand do Brasil, 2004.

. (Dir.) O Brasil monárquico. Do Império à República. Tomo II vol. 7. História geral da civilização brasileira. Rio de Janeiro: Bertrand do Brasil, 2005.

(Dir.) O Brasil monárquico. Reações e transações. Tomo II vol. 5.lização brasileira. Rio de Janeiro: Bertrand do Brasil, 2004.

O extremo Oeste. São Paulo: Brasiliense; Secretaria de Estado da Cultura, 1986.

Raízes do Brasil. 11a ed. Rio de Janeiro: J. Olympio, 1977.

HOUAISS, Antonio. Novo dicionário Houaiss da língua portuguesa. Rio de Janeiro: Objetiva, 2009.

HUISMAN, Denis. História do Existencialismo. Trad. Maria Leonor Loureiro. Bauru: EDUSC, 2001.

HUTCHEON, Linda. Uma teoria da paródia: Ensinamentos das formas de arte do século XX. Trad. Teresa Louro Pérez. Lisboa: Edições 70, 1989.

JAMESON, Fredric. "O romance histórico ainda é possível?" In: Novos Estudos CEBRAP. N.77. Março, 2007.

JASPERS, Karl. A situação espiritual do nosso tempo. Lisboa: Moraes Editores, 1968.

JOLIVET, Régis. As Doutrinas Existencialistas - de Kierkegaard a Sartre. 3ạ. Ed. Trad. Antonio de Queirós Vasconcelos e Lencastre. Porto: Tavares Martins, 1961.

CRESTANI, Jaison Luiz. A colaboração de Machado de Assis no Jornal das Famílias: subordinações e subversões.

KAUFMANN, Vincent. "L'arrière-garde vue de I'avant". In: MARX, William. (org,). Les arrièregardes au XXe siècle. Paris: Quadrige/PUF, 2014, pp. 23-35.

LAFETÁ, João Luiz. 1930: A crítica e o modernismo. 2a ed. 1ạ reimpr. São Paulo: Duas Cidades, Ed. 34, 2001.

LEITE, Ligia Chiappini Moraes Leite. O foco narrativo. 6a ed. São Paulo: Ática, 1993. (Serie Princípios).

LIMA, Alceu Amoroso. "Baseado em O Sentido da Nossa Vitória". In: Notas para a história do Centro Dom Vital. Rio de Janeiro: Educam Paulinas, 2001. 
"O Existencialismo e outros mitos do nosso tempo". In: Obras completas de Alceu Amoroso Lima, vol. XVIII. Rio de Janeiro: Livraria Agir, 1956.

LIMA, Luiz Costa. "As linguagens do Modernismo". In: ÁVILA, AFFONSO. O Modernismo. 2ä. Ed. São Paulo: Perspectiva, 2002, pp.69-86

LOPES, Nei. Novo Dicionário Banto do Brasil. Rio de Janeiro: Pallas, 2003

MACHADO, Regina M. A. Fiction et café dans une vallée impériale : Trois romans de la fazenda esclavagiste au Brésil. Pref. John Gledson. Paris: Indigo, 2011.

MATOS, Odilon Nogueira de. "Vias de comunicação". In: HOLANDA, Sérgio Buarque de. (Dir.). O Brasil monárquico. Declínio e queda do Império. Tomo II vol. 6. História geral da civilização brasileira. Rio de Janeiro: Bertrand do Brasil, 2004, pp. 58-67.

MARINGONI, Gilberto. "O destino dos negros após a abolição" In: Revista IPEA Desafios do Desenvolvimento. 2011 [online]. Ano 8 . Edição 70 - 29/12/2011. Disponível em: <http://".ipea.gov.br/desafios/index.php?option=com content\&id=2673\%3Acatid\%3D28\&lt emid=23> Acesso: $20 / 10 / 2017$.

MARQUESE, Rafael de Bivar. "A dinâmica da escravidão no Brasil - Resistência, tráfico negreiro e alforrias, séculos XVII a XIX". Novos estudos - CEBRAP no 74. São Paulo, Março de 2006.

"A Guerra Civil dos Estados Unidos e a crise da escravidão no Brasil." [online] Originalmente apresentado à Conferência Internacional American Civil Wars: The Crisis of the 1860s in the US, Latin America, and Europe realizada na Universidade da Carolina do Sul, março de 2014.2 Disponível em <http://www.iri.usp.br/documentos/paper_rafael_marquese.pdf> Acesso: 20/05/2017.

MARX, William. "Penser les arrière-gardes". In: ___ (org,). Les arrière-gardes au XXe siècle. Paris: Quadrige/PUF, 2014, pp. 5 -19.

MATTOS, Ilmar Rohloff de. O tempo saquarema. 5.ed. São Paulo: Hucitec, 2004.

MAYER, Arno, J. "Introdução". In: A força da tradição - A persistência do Antigo Regime.Trad. Denise Bottmann. São Paulo: Companhia das Letras, 1987.pp.13-25.

MERQUIOR, José Guilherme. "O modernismo brasileiro (esquema)". Trad. Hilda Merquior. In: O fantasma romântico e outros ensaios. Rio de Janeiro: Vozes, 1980.

MOREIRA, Maria de Fátima Salum. "Gênero em debate: Trajetórias e perspectivas na historiografia contemporânea". Rev. bras. Hist. [online]. 2000, vol.20, n.39, pp.297-300, Disponível em <http://dx.doi.org/10.1590/S0102-01882000000100014> Acesso: 24/03/2017. 
MOTT, Luiz. "Cotidiano e vivência religiosa: entre a capela e o calundu". In: SOUZA, Laura de Mello e. (org). História da Vida Privada no Brasil: cotidiano e vida privada na América. 9a.reimpr. v.l, São Paulo: Companhia das Letras, 1997.

MOUNIER, Emmanuel. Introdução aos existencialismos. Trad. João Bénard da Costa. São Paulo: Duas Cidades, 1963.

MURICY, Andrade. Panorama do movimento simbolista brasileiro. Pref. João Alexandre Barbosa. 3.ed. São Paulo: Perspectiva, (s.d.).

OTSUKA, Edu Teruki. "Espírito rixoso: para uma reinterpretação das Memórias de um sargento de milícias". In: Revista do IEB № 44, fev 2007.

PEREIRA, Lúcia Miguel. A valorização da mulher na sociologia histórica de Gilberto Freyre, In: AMADO, Gilberto et al. Gilberto Freyre - sua ciência, sua filosofia, sua arte: ensaios sobre o autor de "Casa-Grande \& Senzala" e sua influência na moderna cultura do Brasil. Comemorativo do 25ㅇaniversário da publicação deste seu livro. Rio de Janeiro: José Olympio, 1962.

PERROT, Michelle. (Org.) História da vida privada: Da revolução francesa à primeira guerra. Trad. BOTTMANN, Denise; JOFFILY, Beranardo. São Paulo: Companhia das Letras, 2003.

PRADO JR., Caio. Formação do Brasil Contemporâneo. 23ạ ed., 7ạ reimpr. São Paulo: Brasiliense, 1994.

História econômica do Brasil. 17ạ ed. São Paulo: Brasiliense, 1974.

PREMINGER, Alex; BROGAN, T.V.F. (ed.). The new Princeton encyclopedia of poetry and poetics. New Jersey: Princeton University, 1993.

PRIORE, Mary Del. Mulheres no Brasil colonial. 2.ed. São Paulo: Contexto, 2003. (Repensando a História).

PRIORE, Mary Del. (Org.) História das mulheres no Brasil. 8a ed. São Paulo: Contexto, 2006. QUEIROZ, Maria Isaura Pereira de. Singularidades sócio-culturais do desenvolvimento brasileiro. In: Cultura, sociedade rural, sociedade urbana no Brasil. Rio de janeiro: Livros Técnicos e Científicos; São Paulo: Editora EDUSP, 1978.

RONCARI, Luiz. O Brasil de Rosa: mito e história no universo rosiano. 1a reimpr. São Paulo: Editora UNESP, 2004.

SAMARA, Eni de Mesquita. "A família no Brasil: História e Historiografia no século XX". In: Francisco Chacón Jiménez... et al. Sin distancias: Família e tendencias historiográficas em el siglo XX. Universidad de Murcia - Universidad Externado de Colombia, 2002, pp.99-115.

As mulheres, o poder e a família: São Pulo, século XIX. São Paulo: Arco Zero; Secretaria de Estado da Cultura de São Paulo, 1989. 
SARTRE, Jean-Paul. O existencialismo é um humanismo. Petrópolis: Vozes, 2010.

. "La recherche de l'être"; "L'être avec (Mitsein) et le 'nous'". In: L'être et le néant. Essai d'ontologie phénoménologique. França: Gallimard. s/d, pp.11-34; 464-482.

SCHWARZ, Roberto. "A poesia envenenada de Dom Casmurro". In: Duas meninas. 2.ed. São Paulo: Companhia das Letras, 2006, pp 9-41.

. "Ideias fora do Lugar". In: Ao vencedor as batatas - Forma literária e processo social nos inícios do romance brasileiro. São Paulo: Duas Cidades; Ed. 34, 2000.

Um mestre na periferia do capitalismo. 4a ed. São Paulo: Duas Cidades; Editora 34, 2000.

SIMON, lumna Maria. Esteticismo e Participação: as vanguardas poéticas no contexto brasileiro (1954-1969)". In: Novos Estudos CEBRAP. no 26. Março 1990.

SOHIET, Rachel e PEDRO, Joana Maria. "A emergência da pesquisa da História das Mulheres e das Relações de Gênero". In: Revista Brasileira de História [online]. Dez. 2007, vol.27, no 54. pp. 281-300. Disponível em <http://www.scielo.br/scielo.php?pid=S010201882007000200015\&script=sci_abstract\&tlng=pt> Acesso: 22/05/2017.

SOUZA, Gilda de Mello e. 0 espírito das roupas: a moda do século dezenove. 6ạ reimpr. São Paulo: Companhia das Letras, 2009.

Cidades, 1980.

"Teatro ao Sul". In: $\mathbf{O}$ baile das quatro artes: Exercícios de Leitura. São Paulo: Duas

SOUZA, Laura de Mello e. (Org.). História da vida privada no Brasil: cotidiano e vida privada na América Portuguesa. São Paulo: Companhia das Letras, 1997. (História da Vida Privada no Brasil, vol. 1).

STEGAGNO-PICCHIO, Luciana. História da literatura brasileira. Rio de Janeiro: Nova Aguilar, 1997.

TODOROV, Tzvetan. Introduction à la littéarture fantastique. Paris : Éditions du Seuil, (s.d.).

VASCONCELOS, Sandra Guardini. "Romance gótico: persistência do romanesco" e "Subjetividade e mundo doméstico no romance". In: Dez lições sobre o romance inglês do século XVIII. São Paulo: Boitempo, 2002.

VILLAÇA, Antonio Carlos. O pensamento católico no Brasil. Rio de Janeiro: Zahar, 1975.

WAHL, Jean. Historia del existencialismo. Trad. Bernard Guillen. Buenos Aires: Dedalo, 1960. 
WELLEK, René; WARREN, Austin. Teoria da literatura e metodologia dos estudos literários. Trad. Luis Carlos Borges. São Paulo: Martins Fontes, 2003.

WILSON, Edmund. O castelo de Axel: estudo sobre a literatura imaginativa de 1870 a 1930 . Trad. José Paulo Paes. 2a ed. São Paulo: Companhia das Letras, 2004. 